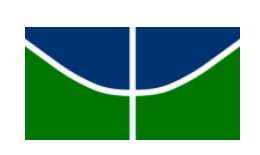

UNIVERSIDADE DE BRASÍLIA

FACULDADE DE EDUCAÇÃO FÍSICA

PROGRAMA DE PÓS-GRADUAÇÃO STRICTO-SENSU EM

EDUCAÇÃO FÍSICA

SAÚDE RELACIONADA AO CONTEXTO DE TRABALHO, AO AUTOCUIDADO APOIADO E AO CUIDAR DE SI EM PROFESSORES UNIVERSITÁRIOS DE EDUCAÇÃO FÍSICA.

Andrea Ferreira Leite

BRASÍLIA, 2016 
SAÚDE RELACIONADA AO CONTEXTO DE TRABALHO, AO AUTOCUIDADO APOIADO E AO CUIDAR DE SI EM PROFESSORES UNIVERSITÁRIOS DE EDUCAÇÃO FÍSICA.

ANDREA FERREIRA LEITE

Dissertação apresentada à Faculdade de Educação Física da Universidade de Brasília, como requisito parcial para a obtenção do grau de Mestre em Educação Física.

ORIENTADORA: JÚLIA APARECIDA DEVIDÉ NOGUEIRA 
Ficha catalográfica elaborada automaticamente, com os dados fornecidos pelo(a) autor(a)

\begin{tabular}{|c|c|}
\hline \multirow[t]{3}{*}{ LS } & $\begin{array}{l}\text { Leite, Andrea Ferreira } \\
\text { Saúde Relacionada ao Contexto de Trabalho, ao } \\
\text { Autocuidado Apoiado e ao Cuidar de Si em Professores } \\
\text { Universitários de Educação Física / Andrea Ferreira } \\
\text { Leite; orientador Júlia Aparecida Devidé Nogueira. } \\
\text { - Brasilia, 2016. } \\
\quad 132 \text { p. }\end{array}$ \\
\hline & $\begin{array}{l}\text { Dissertação (Mestrado - Mestrado em Educação Física) } \\
\text {-- Universidade de Brasília, } 2016 .\end{array}$ \\
\hline & $\begin{array}{l}\text { 1. promoção da saúde. } 2 \text {. cuidado de si. } 3 . \\
\text { adoecimento. 4. práticas corporais. } 5 . \text { atividades } \\
\text { físicas. I. Nogueira, Júlia Aparecida Devidé, } \\
\text { orient. II. Título. }\end{array}$ \\
\hline
\end{tabular}




\section{SAÚDE RELACIONADA AO CONTEXTO DE TRABALHO, AO AUTOCUIDADO APOIADO E AO CUIDAR DE SI EM PROFESSORES UNIVERSITÁRIOS DE EDUCAÇÃO FÍSICA.}

Dissertação apresentada à Faculdade de Educação Física da Universidade de Brasília, como requisito parcial para a obtenção do grau de Mestre em Educação Física.

BANCA EXAMINADORA

Profa. Dra. Júlia Aparecida Devidé Nogueira (PPGEF/FEF/UnB)

(Presidente)

Profa. Dra. Jacqueline Rodrigues Lima (PRPG-MEPES/UFG)

(Membro Efetivo Externo)

Prof. Dr. Edson Marcelo Húngaro (PPGEF/FEF/UnB)

(Membro Efetivo)

Prof. Dr. Alexandre Luiz Gonçalves de Rezende (PPGEF/FEF/UnB)

(Membro Suplente)

Brasília, 24 de Agosto de 2016. 
DEDICATÓRIA

Dedico esse trabalho a minha família por terem incentivado desde os primeiros passos da minha vida escolar, especial meu avô Agostinho Loretti Leite (in memorian) que sempre disse "você é capaz minha neta" e aos meus professores, que me fizeram e fazem acreditar no poder da educação. 


\title{
AGRADECIMENTOS
}

\author{
Agradecer... \\ É bom poder agradecer! \\ E tenho muito a agradecer... \\ Obrigada Deus, por me permitir a realização deste sonho.
}

Agradeço em especial à minha família, meus pais, meus irmãos, minha sobrinha, meu querido marido e minha filha linda, por tudo que vivemos e por estarem sempre presentes. Sei o significado e importância que esse momento tem para todos nós. Dedico a vocês a conclusão desta etapa. E que venham outras...

Agradeço ao Wagner Alberto, meu esposo, companheiro e amigo de todas as horas, que estimulou e apoiou desde o início minha decisão de seguir esse caminho. Obrigado por participar das alegrias e dificuldades dessa fase que deixam um aprendizado e a certeza de que sua presença e força foram essenciais nesse momento da minha vida.

Agradeço a minha Filha Maria Clara que mesmo com poucos anos de vida (três anos) entendeu que a mamãe tinha que estudar e falava com carinho "mamãe, eu não vou chorar, já sou mocinha, não choro, vou deixar você estudar" e me dava um beijo e um abraço forte. E nos finais de semana quando tinha que ir a biblioteca estudar, ela fazia questão de entrar comigo e ficar um pouco sentada na biblioteca, falando baixinho para não atrapalhar as outras pessoas e dizendo que estava estudando.

Agradeço a minha orientadora Júlia Nogueira, pelo apoio firme, pela paciência, pela dedicação, e pelo cuidado em todos os momentos de nossa parceria. Agradeço os conselhos, o companheirismo, os sorrisos e as experiências compartilhadas, os quais levarei como referência em minha caminhada. Obrigado ainda pela confiança, por ter me ajudado a crescer neste novo caminho. Espero poder contar com sua experiência e amizade em outros momentos.

Aos amigos do SESI que me apoiaram nessa jornada, em especial aos que puderam acompanhar mais de perto esse momento: Felipe, Geórgia e Gina. Agradeço em especial aos Gerentes do SESI.

Agradeço ao grupo de estudo em Saúde Coletiva e Equidade que, de forma calorosa, acreditaram e me incentivaram (Ciro Queiroz, Felipe Saul, Francilene Madeira, Hetty Lobo, Iraneide Lopes, Jorge Almeida e Rafael Barros). Obrigado pela nossa convivência prazerosa.

Agradeço aos colaboradores e professores da Faculdade de Educação Física e os da PósGraduação que estiveram sempre presentes nessa jornada; bem como os participantes da pesquisa. E a todos que de alguma forma somaram para que esse trabalho fosse concluído. 
"Se eu pudesse deixar algum presente a você, deixaria aceso o sentimento de amor à vida dos seres humanos. A consciência de aprender tudo o que foi ensinado pelo tempo a fora. Lembraria os erros que foram cometidos como sinais para que mais se repetissem. A capacidade de escolher rumos. Deixaria para você, se pudesse, respeito àquilo que é indispensável: além do pão, o trabalho. Além do trabalho, a ação. E, quando tudo mais faltasse, para você eu deixaria, se pudesse, um segredo: de buscar no interior de si mesmo a resposta para encontrar a saída."

Gandhi

"Ninguém nasce feito, é experimentando-nos no mundo que nós nos fazemos."

Paulo Freire 


\section{LISTA DE TABELAS}

\section{Página}

Tabela 1. Características da população da FEF-UnB, dos professores elegíveis e da amostra estudada na primeira etapa da pesquisa, realizada no segundo semestre de 2015 . 64

Tabela 2. Escala de avaliação do contexto de trabalho com bases em suas três dimensões analíticas e de acordo com características da amostra de docentes da FEF-UnB. 66

Tabela 3. Características gerais dos docentes participantes da etapa qualitativa da pesquisa na FEF-UnB; 2015. 69 


\section{LISTA DE QUADROS}

\section{Página}

Quadro 1. Delineamento metodológico do estudo desenvolvido com professores da Faculdade de Educação Física da Universidade de Brasília; 2015. 46

Quadro 2: Características das publicações sobre saúde e fatores associados em professores universitários da área da saúde.

Quadro 3. Prevalência de professores da FEF que responderam que a UnB "NÃO” ofereceu suporte organizacional à Promoção da Saúde, em cada uma das nove questões.

Quadro 4. Prevalência de professores da FEF que responderam que a UnB "NÃO” ofereceu suporte organizacional à Atividade Física, em cada uma das nove questões. 68 Quadro 5. Prevalência de professores da FEF que responderam que a UnB "NÃO” ofereceu suporte organizacional ao gerenciamento de estresse, em cada uma das seis questões. 68 


\section{LISTA DE FIGURAS}

\section{Página}

Figura 1. Os Determinantes Sociais da Saúde............................................................... 23

Figura 2. Marco conceitual das Universidades Saudáveis. ..................................................27

Figura 3. Dimensões interdependentes que compõem a Escala de Avaliação do Contexto de Trabalho. 32

Figura 4. Os três componentes do Cartão de Pontuação do Apoio à Saúde no Local de Trabalho utilizados para avaliar a Universidade de Brasília. 33

Figura 5. O Distrito Federal e suas 31 Regiões Administrativas. ........................................ 38

Figura 6. A Região Administrativa de Brasília com destaque para o Plano Piloto................. 41

Figura 7. O Campus Darcy Ribeiro da Universidade de Brasília. 43

Figura 8. A área central da Universidade de Brasília (em vermelho) e a Faculdade de Educação Física. 61

Figura 9. Faculdade de Educação Física, Universidade de Brasília......................................62

Figura 10. Modelo esquemático de categorias analíticas do estudo e suas interrelações........ 70

Figura 11. Esquema da Categoria Saúde e suas Subcategorias........................................... 71

Figura 12. Esquema da Categoria Contexto de Trabalho e suas Subcategorias..................... 75

Figura 13. Esquema da Categoria Autocuidado e suas Subcategorias................................... 80

Figura 14. Esquema de interconexões das percepções sobre Promoção da Saúde. ................ 85 


\section{LISTA DE ABREVIATURAS E SIGLAS}

CAPES Coordenação de Aperfeiçoamento de Pessoal de Nível Superior

DF Distrito Federal

DP Desvio Padrão

FEF Faculdade de Educação Física

IES Instituição de Ensino Superior.

OMS Organização Mundial de Saúde.

PNPS Política Nacional de Promoção da Saúde.

REUNI Reestruturação e Expansão das Universidades Federais.

TCLE Termo de Consentimento Livre e Esclarecido.

UnB Universidade de Brasília. 


\section{RESUMO}

Introdução: A saúde humana é um fenômeno complexo, centrado na busca da conservação ou expansão da vitalidade vista como totalidade irredutível, e determinada através da interação do sujeito com o ambiente em que vive, incluindo o trabalho. O conceito de promoção da saúde destaca o papel de indivíduos e organizações na criação de oportunidades, escolhas e ambientes saudáveis mediante comprometimento social e político com o desenvolvimento sustentável e a redução das iniquidades. Nessa perspectiva, a universidade é um espaço social estratégico para a promoção da saúde, seja por meio da produção de conhecimentos, da formação profissional, ou do estímulo à saúde de grupos populacionais a ela relacionados. Não obstante, o cotidiano acadêmico com demandas crescentes por produtividade e o imediatismo digital tem provocado mudanças nas formas de organização do trabalho e na saúde dos docentes. Objetivo: Diante desse cenário, o presente estudo tem como objetivo compreender o fenômeno da saúde relacionando-o ao contexto de trabalho, ao apoio institucional promotor do autocuidado, e ao cuidar de si, com especial atenção às práticas corporais, a partir da percepção dos professores da Faculdade de Educação Física (FEF) da Universidade de Brasília (UnB). Metodologia: A pesquisa foi desenvolvida em três etapas complementares: os processos exploratórios de revisão da literatura e imersão no contexto da pesquisa; a trabalho de campo e a coleta de dados por meio de dois questionários e uma entrevista semi-estruturada para caracterização do contexto de trabalho e do apoio institucional ao autocuidado; e o processo reflexivo visando dar sentido ao conjunto de informações. A população da pesquisa foram os 38 docentes da FEF-UnB em efetivo exercício no ano de 2015. Resultados: Vinte e dois docentes responderam aos questionários e nove professores participaram das entrevistas. No geral os professores percebem um contexto moderado a critico de trabalho que necessita de melhoras, e não identificam o apoio da UnB ao autocuidado em saúde, com exceção à estrutura física para a prática de atividade física na FEF. As entrevistas permitiram aprofundar a compreensão sobre a saúde, em termos de sua situação (positiva ou negativa), de suas esferas (física, mental, emocional, espiritual, e/ou integral) e de sua relação com o contexto de trabalho, incluindo o apoio institucional ao autocuidado. O cuidar de si e a percepção sobre promoção da saúde, como um conceito que norteia os discursos e as práticas relatadas, também foram explorados. As interrelações observadas entre a saúde, o trabalho, o apoio institucional e o cuidar de si fogem ao modelo dual e linear e carecem de um olhar complexo que possibilite sua exploração e possa subsidiar estratégias e políticas inovadoras, dinâmicas, ativas e participativas que atendam melhor às necessidades contemporâneas em promoção da saúde no ambiente universitário. Conclusões: Os professores identificam diversos aspectos negativos à saúde no contexto de trabalho, principalmente relacionados às diversas atividades profissionais que, sobrepostas e alinhadas ao modelo produtivista, acabam por representar fonte de sofrimento e angustia. Mas também são capazes de mobilizar recursos disponíveis na busca de soluções criativas para tornar o trabalho possível e, também, obter resultados positivos no exercício de sua profissão e em sua saúde. O professor de educação física, como profissional da área de saúde e também da educação, não pode ser um mero transmissor de conhecimento, mas sim um agente de transformação social, o que pode ampliar a pressão e o sofrimento relacionados ao trabalho provocando um paradoxo que Jung denominou de o "curador adoecido". A universidade precisa de profissionais, alunos e comunidade que ajudem a repensar seu papel de instituição promotora da saúde.

Palavras Chaves: promoção da saúde, cuidado de si, adoecimento, práticas corporais, atividades físicas. 


\section{ABSTRACT}

Introduction: Human health is a complex phenomenon, centered in the pursuit of conservation or expansion of vitality seen as irreducible totality, and determined by the subject's interaction with the environment in which he lives, including work. The concept of health promotion emphasizes the role of individuals and organizations in creating opportunities, choices and healthy environments through social and political commitment to sustainable development and reduction of inequalities. In this perspective, the university is a strategic social context for the promotion of health, either through the production of knowledge, training, or encouraging the population health related to it. Nevertheless, the dayby-day of academic with increasing demands for productivity and digital immediacy has caused changes in the forms of work organization and health of teachers. Objective: In this scenario, this study aims to understand the health phenomenon relating it to the work context, institutional support promoting self-care, and to care for themselves, with special attention to body practices, from the perception of the Faculty of Physical Education (FEF for its name in Portuguese) at the University of Brasilia (UNB). Methodology: The research was conducted in three complementary stages: the exploratory process of review of the literature and immersion in the context of research; the work to the field and collecting data through two questionnaires and a semi-structured interview to characterize the work context and institutional support for self-care; and the reflective process to make sense of the information set. The population of the research were 38 teachers FEF-UNB in effective exercise in 2015. Results: Twenty-two teachers answered the questionnaires and nine teachers participated in the interviews. Overall teachers realize a critical context to moderate work that needs improvement, and does not identify the support of UNB to self treatment, except the physical infrastructure for physical activity in the FEF. The interviews allowed deepen the understanding of health, in terms of status (positive or negative), their spheres (physical, mental, emotional, spiritual, and / or full) and its relation to the work context, including institutional support self-care. The care for themselves and the perception of health promotion as a concept guiding the discourses and practices reported, were also explored. The interrelations observed between health, work, institutional support and take care of themselves beyond the dual and linear model and lack a complex look that allows their operation and can support innovative policies and strategies, dynamic, active and participative better serve to contemporary needs in health promotion in the university environment. Conclusions: Teachers identify several negative aspects to health in the workplace, mainly related to various professional activities, overlapping and aligned to the productivist model, ultimately represent a source of suffering and anguish. But they are also able to mobilize available resources in the search for creative solutions to make the work possible and also get positive results in the exercise of their profession and their health. The physical education teacher, as a professional healthcare and also education, can not be a mere transmitter of knowledge, but rather a social change agent, which can increase the pressure and suffering related to work causing a paradox that Jung termed the "sick healer." The university needs professionals, students and the community to help rethink its role in promoting the health institution.

Key words: health promotion, self care, illness, bodily practices, physical activities. 


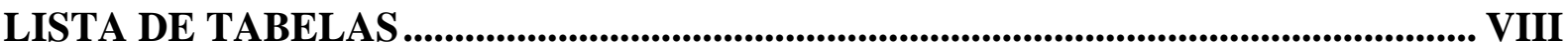

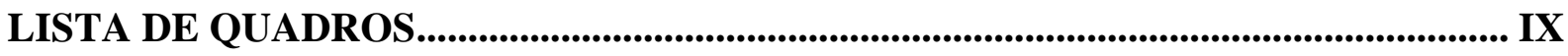

LISTA DE ABREVIATURAS E SIGLAS ................................................................................. XI

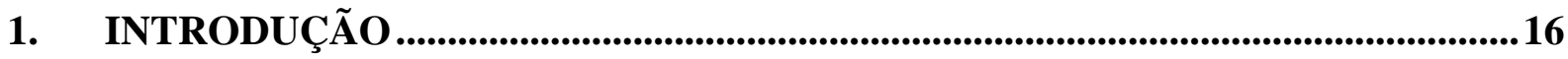

2. REFERÊNCIAL TEÓRICO ............................................................................................20

2.1 A saúde e a promoção da saúde como fenômenos contemporâneos .........................20

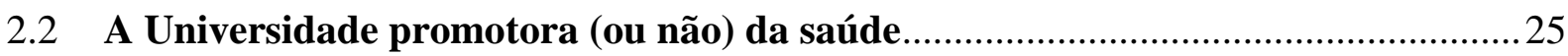

$2.3 \quad$ o contexto de trabalho dos docentes universitários ...............................................28

$2.4 \mathrm{O}$ autocuidado apoiado (institucional) e a prática do cuidar de si .......................... 32

2.5 As práticas corporais e atividades físicas como cuidado de si ................................ 35

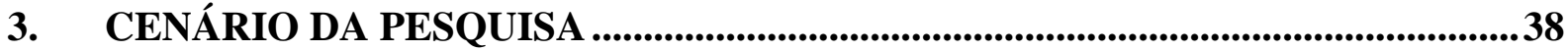

3.1 O Contexto da Universidade de Brasília no Distrito Federal ....................................38

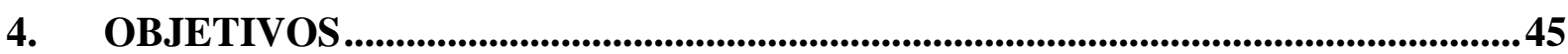

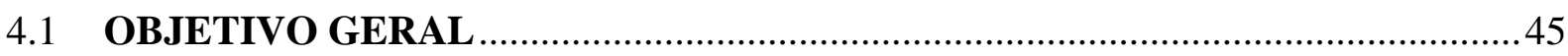

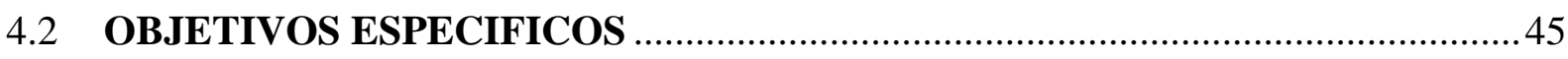

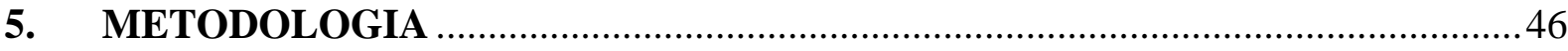

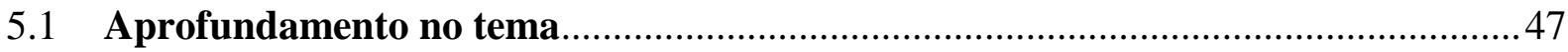

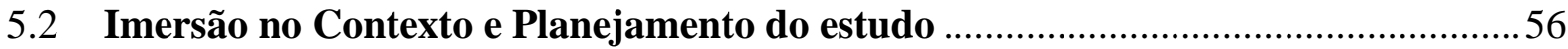

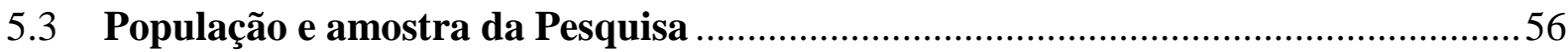

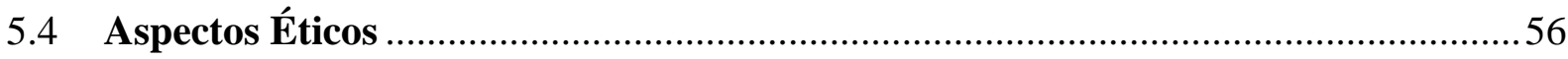

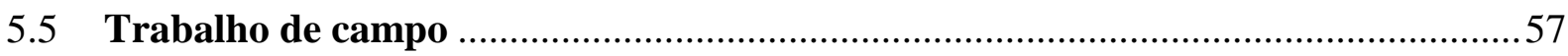

5.5.1 Aplicação dos questionários em professores universitários da FEF …..................57

5.5.2 A Entrevista com os professores universitários da FEF ........................................59

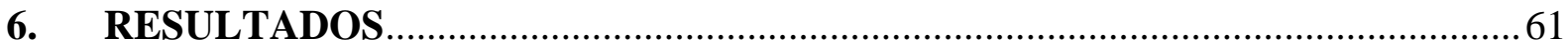

6.1 Caracterização do cenário de pesquisa: a FEF-UnB ............................................ 61

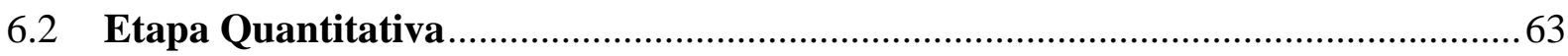

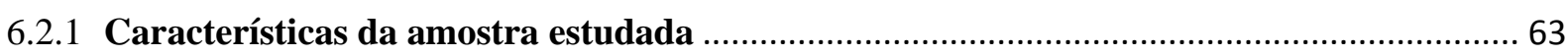

6.2.2 Análise do Questionário Escala de Avaliação do Contexto de Trabalho ............................. 65

6.2.3 Análise do Questionário de Saúde no Ambiente de Trabalho ……..................................... 67

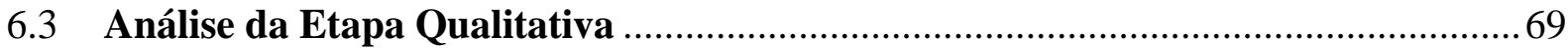












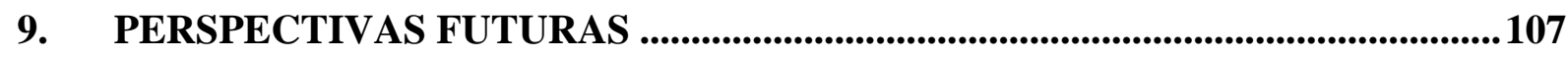

10. REFERÊNCIAS BIBLIOGRÁFICAS ....................................................................108

LISTA DE APÊNDICES ................................................................................................. 124

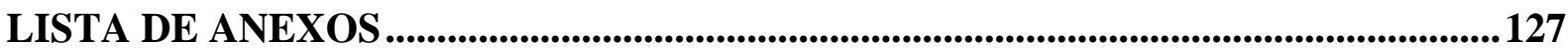




\section{INTRODUÇÃO}

O presente estudo surgiu do interesse em compreender o fenômeno da saúde em relação à atividade laboral do professor universitário que atua na grande área da saúde. Isso porque as transformações modernas apresentam novos paradigmas e dinâmicas a diversos fenômenos sociais, desafiando sujeitos e coletividades - em especial àqueles atuantes nos campos da saúde - a vivenciar e a produzir saúde na contemporaneidade (CAMPOS, 2003; BAUMAN, 2001).

Ao adotar uma concepção ampliada de saúde como sendo um processo centrado na busca da conservação ou expansão da vitalidade humana, vista como totalidade irredutível, que inclui a interação do sujeito com o ambiente em que vive (LUZ, 2007), é necessário considerar a conjuntura atual. A evolução tecnológica, a hiperconectividade, o avanço das ideologias neoliberais e da austeridade econômica no contexto produtivo, e os novos valores culturais, tais como imediatismo, individualismo, narcisismo, consumismo e hedonismo, dentre outros; afetam as relações e a saúde humanas (BAUMAN, 2001).

No contexto do trabalho, essas mudanças tanto proporcionam quanto demandam dos profissionais imediatismos resolutivos e atualizações constantes, afetando o ritmo e a capacidade de assimilação das tarefas, e a saúde e a qualidade de vida dos trabalhadores. A vida no trabalho passa a existir numa temporalidade de aceleração permanente em busca de produtividade e competência, com o aumento dos dispositivos de controle que enfatizam ligações funcionais e pragmáticas dos trabalhadores no seu cotidiano (MANCEBO; ROCHA, 2002).

Diante desse cenário, as universidades - espaços reconhecidos de produção de conhecimentos e de formação profissional - deveriam também se constituir em espaços que apoiem o desenvolvimento de posturas críticas diante da realidade social, e de valores e atitudes relacionados à promoção da vida e da saúde (MELLO; MOYSÉS; MOYSÉS, 2009). O ambiente universitário tem enorme potencial para proteger e fomentar a saúde dos estudantes, docentes, funcionários técnico-administrativos e comunidade em geral por meio de atividades sustentáveis de promoção da saúde por meio da conservação do meio-ambiente, criação de ambientes físicos saudáveis, e atividades de ensino, pesquisa e extensão (ROCHA, 2008). Nesses processos produtores de vida e de saúde, o docente universitário, especialmente aqueles que atuam na grande área da saúde, apresenta papel preponderante (RIBEIRO; CIAMPONE, 2008). 
No entanto, as Instituições de Ensino Superior (IES) brasileiras não necessariamente se orientem por parâmetros promotores da saúde (MELLO; MOYSÉS; MOYSÉS, 2009). Em decorrência das novas tecnologias, de mudanças no sistema educacional e nas formas de organização do trabalho, a intensificação das exigências por geração de conhecimentos, formação profissional de qualidade e produção de novas tecnologias para o país se consolidam como tarefas adicionais aos docentes universitários (COUTINHO; MAGRO; BUDDE, 2011; FERNANDES, 1996; MANCEBO; ROCHA, 2002). Alguns professores, apesar de excelentes em sua área de atuação, passam a apresentar dificuldade em cumprir as atividades de ensino, pesquisa e extensão contempladas no "tripé universitário" e ainda se dedicar às atividades administrativas e financeiras que se acumulam na sua carga de responsabilidades (MELLO; MOYSÉS; MOYSÉS, 2009). Tais sobrecargas vêm apresentando consequente impacto sobre a vida e a saúde dos docentes (FERREIRA, 2011; FONTANA; PINHEIRO, 2010; SERVILHA; ARBACH, 2011).

O esgotamento advindo de pressões e cobranças presentes na organização do trabalho pode ser uma causa preocupante de sofrimento e adoecimento (DEJOURS; ABDOUCHELI E JAYET, 2010), especialmente porque o processo intelectual, investigativo e criativo do docente não se encaixa na lógica produtivista (GARCIA; OLIVEIRA; BARROS, 2008). Não obstante, o trabalho também pode ser uma fonte de prazer e realização pessoal (LAURELL, 1989). O desafio de superar as dificuldades pode estimular a criação de estratégias e regras que redefinem a técnica, gerando modos de regulação que deem conta da variabilidade inerente à atividade laboral, fazendo emergir o trabalho real, que afirma a potência dos seres vivos de reorganizarem cotidianamente suas demandas (DEJOURS, 1999). Vieira Jr. (2011) nos ajuda a compreender as diferenças entre o trabalho prescrito e trabalho real:

"O trabalho docente, como toda atividade de trabalho, também é formado pelo trabalho prescrito e pelo trabalho real. O trabalho docente prescrito é formalizado pelos gestores educacionais externos e internos e tem por finalidade orientar as funções e tarefas dos docentes em suas atividades escolares. O trabalho docente real seria o que é constituído e realizado por cada professor na especificidade de cada Instituição de Ensino Superior, na singularidade de cada turma, nas características de cada aluno inserido em diferentes realidades. Igualmente, esse trabalho real recebe influência dos valores, escolhas, crenças, arbitragens e história de vida desse docente" (pág. 65-66). 
Outros aspectos de prazer e realização para o docente são o reconhecimento profissional e a criação de vínculos (um componente básico do processo de aproximação e interesse pela vida social), elementos importantes para enfrentar as adversidades e suportar os níveis de estresse, angústia e de falta de sentido no trabalho (GARCIA; OLIVEIRA; BARROS, 2008; LEMOS, 2005)

Reconhecemos assim que o contexto e as condições de trabalho e o apoio institucional são elementos relevantes na produção de prazer, sofrimento, saúde e adoecimento profissional. Não como forças contraditórias e conflitantes, mas como forças que coexistem no ambiente de trabalho (MENDES, 2007). Nessa perspectiva, nos aproximamos do conceito de autocuidado apoiado, que destaca o papel das organizações na criação de oportunidades, escolhas e ambientes saudáveis, mas também reconhece as responsabilidades individuais no cuidado de si (MELLO; MOYSÉS; MOYSÉS, 2009; MENDES; NETO; JUNIOR PEREIRA, 1996).

No caso das universidades o tema se torna ainda mais oportuno por se tratar do ambiente onde muitos vivenciam e experimentam vários aspectos da vida: aprendem, trabalham, socializam e usufruem o tempo livre (SILVA; BRITO, 2014); onde se estudam esses fenômenos de saúde e se formam os profissionais para atuar na sociedade contemporânea (MELLO; MOYSÉS; MOYSÉS, 2009). A atuação específica dos docentes da área da saúde traz outro aspecto adicional ao estudo da temática das relações de saúde, trabalho e autocuidado: a relevância da produção do cuidado para com a defesa e a afirmação da saúde e da vida (SILVA; OLIVEIRA; SILVA, et al., 2008). Não obstante, essa especificidade pode produzir uma vivência paradoxal: mesmo sendo autoridade científica na área, o professor da área de saúde pode não conseguir agir ou "promover a saúde" de forma satisfatória ou em conformidade com as recomendações que ensina (GUBA; LINCOLN, 2011); se aproximando de um arquétipo que Jung (1989) definiu como “o curador adoecido".

Sendo um profissional da área da saúde, o professor de educação física vem experimentando a ampliação e complexificação da interface de seu campo de trabalho e estudo com a saúde, seja na prevenção de doenças crônicas e agudas, seja na recuperação terapêutica, ou na promoção da saúde (LUZ, 2007). As práticas corporais e atividades físicas ganham reconhecimento e valor como ação de autocuidado (CAVALCANTI; OLIVEIRA, 2012); atividades voluntárias, deliberadas e intencionais que os indivíduos desempenham em seu próprio benefício com o propósito de manter a vida, a saúde e o bem-estar (BUB, et al. 2006). O cuidar de si envolve o desenvolvimento de técnicas que permitam aos indivíduos 
efetuarem, sozinhos ou com a ajuda de outros, certo número de operações sobre seus corpos e suas almas, seus pensamentos, suas condutas e seus modos de ser; de se transformarem a fim de atender certo estado de felicidade, de pureza, de sabedoria, de perfeição ou imortalidade (FOUCAULT, 2007).

Diante desse cenário amplo e complexo de interrelações entre o sujeito e o ambiente, o contexto e as condições de trabalho, o apoio institucional e o cuidado de si na produção da saúde, nos interessa refletir sobre os processos que fazem o professor universitário de educação física adotar ações de cuidado e promoção da saúde, em especial as práticas corporais, levando em consideração o contexto de trabalho, o apoio institucional, e as visões de saúde que embasam essas práticas. Acreditamos que, ao explorar esses aspectos, poderemos contribuir com a emergente discussão das Universidades Promotoras de Saúde, contextualizando-a frente aos paradigmas dominantes na formação em saúde e às mudanças sócio-políticas contemporâneas. 


\section{REFERÊNCIAL TEÓRICO}

\subsection{A saúde e a promoção da saúde como fenômenos contemporâneos}

O paradigma moderno de saúde a compreende como um fenômeno complexo centrado na busca da conservação ou expansão da vitalidade humana vista como totalidade irredutível, considerada parte e expressão, ao mesmo tempo, do meio ambiente natural, social, psíquico emocional e espiritual, cujo estudo requer a articulação de diversos saberes (LUZ, 2007). Não obstante, a "normatividade biológica" que demarca a especificidade da ciência moderna ainda permanece hegemônica, estando por trás da tensão entre ciência e filosofia na tentativa de explicar a saúde e a vida (CZERESNIA, 2012). Não se trata de negar as leis da natureza e a perspectiva biológica, mas de reconhecer que esta visão, isoladamente, é incapaz de explicar o fenômeno da saúde no contexto contemporâneo (ASSUMPÇÃO; MORAIS; FONTOURA, 2002).

Atualmente, diversos modelos conceituais de saúde (e consequentemente de práticas em saúde) coexistem podendo, de forma geral, ser agrupados em três níveis: 1) de combate e tratamento às patologias; 2) de prevenção à agravos e controle dos riscos; e 3) de promoção da saúde, focada na modificação dos determinantes sociais da saúde (LUZ, 2007). No entanto é importante destacar a inexistência de uma linha divisória clara entre cada um dos níveis, o que fica explícito nos tensionamentos que emergem das tentativas de definição conceitual do fenômeno (BOSI, 2012).

A Organização Mundial de Saúde define saúde não apenas como a ausência de doença, mas como a situação de completo bem-estar físico, mental e social (OMS, 1946). Entretanto, essa definição indica de forma implícita a impossibilidade de se alcançar tal meta, uma vez que esbarra na dificuldade de se atingir um "perfeito" e "completo" bem-estar (PALMA; ESTEVÃO; BAGRICHEVSKY, 2006). A própria promoção da saúde, em alguns momentos iniciais, como no Relatório Lalonde em 1974, esteve fortemente atrelada à noção de proteção à saúde através do controle dos fatores de risco numa perspectiva individual, resultando em processos de culpabilização do indivíduo por seu adoecimento (SÍCOLI; NASCIMENTO, 2003).

Nos anos 1980, dimensões técnicas tanto em nível da incorporação de inovações e tecnologia como de planejamento e organização da atenção em saúde ou da assistência médica ofuscam em parte os aspectos sociais da saúde (BUSS, 2000). Por sua vez, a noção de Determinantes Sociais de Saúde reaparece junto com movimentos de contestação ao 
pensamento liberal e novas conjunturas políticas, principalmente na América Latina (BREILH, 2006). Diversos autores passam a se dedicar a temática da saúde a partir das Ciências Sociais e Humanas, oferecendo importante contribuição para o debate ao conceber o homem segundo uma lógica distinta daquela estritamente biofisiológica (CARVALHO, 2002). Para essas ciências a realidade não é um dado unívoco, mas uma construção social, que varia segundo a história, as diferentes estruturas e os diferentes processos sociais (LUZ, 2007). Produzir saúde passa a significar contribuir para o aumento do coeficiente de autonomia de indivíduos e coletivos para viver a vida, possibilitando-lhes lidar com as limitações decorrentes da doença, da genética e do contexto psicossocial (WACHS, 2007). As reflexões sistematizadas nesse período afetam profundamente o campo da saúde, resultando em movimentos de ruptura na definição dos conceitos e nas práticas em saúde. A realização da VIII Conferência Nacional de Saúde, da Conferência Internacional de Promoção da Saúde no Canadá que resulta na Carta de Ottawa, e a criação do Sistema Público de Saúde no Brasil são marcos desse processo (SÍCOLI; NASCIMENTO, 2003). Um dos principais aspectos destacados na Carta de Ottawa e no relatório final da VIII Conferência Nacional de Saúde e é o reconhecimento dos Determinantes Sociais de Saúde como aspectos centrais na produção da saúde.

\footnotetext{
"A saúde deve ser vista como um recurso para a vida, e não como objetivo de viver. Nesse sentido, a saúde é um conceito positivo, que enfatiza os recursos sociais e pessoais, bem como as capacidades físicas. Assim, a promoção da saúde não é responsabilidade exclusiva do setor saúde, e vai para além de um estilo de vida saudável, na direção de um bem-estar global" (OMS, 1986, pág.01).
}

"Em seu sentido mais abrangente, a Saúde é o resultante das condições de alimentação, habitação, educação, renda, meio ambiente, trabalho, transporte, emprego, lazer, liberdade, acesso e posse da terra e acesso aos serviços de saúde. É, assim, antes de tudo, o resultado das formas de organização social da produção, os quais podem gerar grandes desigualdades nos níveis de vida" (BRASIL, 8ª Conferência Nacional de Saúde, 1986, pág. 04).

A saúde, nessa perspectiva, é entendida como componente central do desenvolvimento humano, ressaltando os fatores necessários para assegurar a qualidade de vida e o direito ao bem-estar social (BRASIL, 2002). Trata-se, portanto, de um modelo mais abrangente de análise do fenômeno saúde/doença, que o considera como emergente das próprias formas de organização da sociedade. Esse modelo não nega a existência e/ou a relevância do fenômeno 
biológico, muito menos o processo de interação que se estabelece entre o agente causador da doença, o indivíduo suscetível e o ambiente, mas destaca o papel do contexto no processo (BRASIL, 2006; 2006a).

Os Determinantes Sociais de Saúde podem ser dispostos em diferentes camadas interligadas (Figura 1), desde a camada distal, na qual se situam os macrodeterminantes - tais como condições socioeconômicas, culturais, ambientais e políticas que determinam as condições de vida e trabalho, educação, saneamento, dentre outras, que, por sua vez, afetam as redes sociais e comunitárias a que o indivíduo tem acesso, influenciando seus hábitos de vida e sua saúde - até aquela mais próxima dos indivíduos, em que se encontram as características, responsabilidades e escolhas individuais (DAHLGREN; WHITEHEAD, 2007).

"As características individuais de idade, sexo e fatores genéticos evidentemente exercem influência sobre o potencial e as condições de saúde do indivíduo. Na camada imediatamente externa aparecem o comportamento e os estilos de vida individuais. Esta camada está situada no limiar entre os fatores individuais e os determinantes sociais, já que os comportamentos, muitas vezes entendidos apenas como de responsabilidade individual, dependentes de opções feitas pelo livre arbítrio das pessoas, na realidade podem também ser considerados parte dos determinantes, já que essas opções estão fortemente condicionadas por determinantes sociais de saúde como informações, propaganda, pressão dos pares, possibilidades de acesso a alimentos saudáveis e espaços de lazer, dentre outros" (BUSS; FILHO, 2007, pág. 83). 


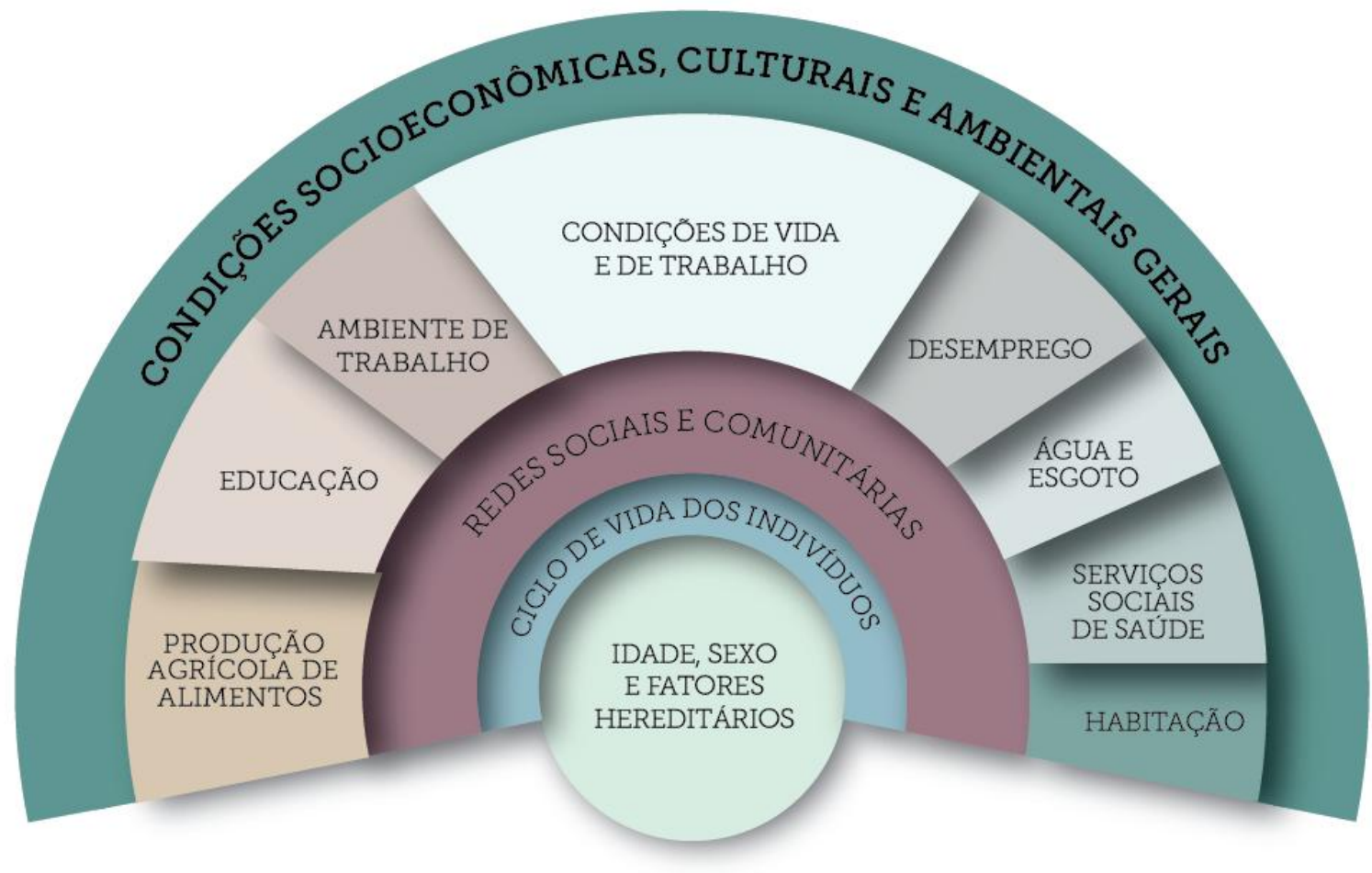

Figura 1. Os Determinantes Sociais da Saúde. (Adaptada de DAHLGREN; WHITEHEAD, 2007).

Esse modelo conceitual moderno em saúde permite identificar pontos para atenuar as desigualdades originadas pela posição social dos indivíduos e grupos (BUSS E FILHO, 2007), e ganha relevância diante das mudanças paradigmáticas na forma de viver e das demandas contemporâneas em saúde, quando o paradigma biomédico hegemônico passa a apresentar dificuldade de responder, sozinho, aos múltiplos desafios e problemas de saúde que afetam as populações humanas (BUSS, 2000) devido ao relacionamento entre os grupos e forças sociais mais amplas (CARVALHO, 2005).

Embora a medicina baseada em evidências, de modo particular, ainda continue subestimando a relevância de intervenções fora do núcleo médico, pouco investigando sobre a eficácia dos determinantes sociais, da educação em saúde, do autocuidado, e da autoanálise (CAMPOS 2003), os núcleos de saberes da Saúde Coletiva tem trabalhado para construir interlocuções com diferentes áreas do conhecimento para pensar ações conjuntas no âmbito das reais necessidades em saúde de nossa sociedade (BOSI; PAIM, 2010).

Não se trata, em absoluto, de negar os avanços que a tecnologia provocou no campo do diagnóstico e no campo terapêutico, mas de reconhecer que o novo perfil epidemiológico que se compõe por enfermidades relacionadas ao fazer e viver das pessoas requer um olhar complexo e integral, voltado para um ambiente salutogênico promotor do autocuidado, 
demandando ações que incorporem no cotidiano social, do indivíduo e da assistência princípios formativos e educativos em saúde (ROCHA; CENTURIÃO, 2007).

Desta forma, o conceito moderno de Promoção da Saúde representa um modelo promissor para superar a perspectiva puramente preventiva e curativa, e para aprofundar a compreensão sobre a complexidade de se preservar os potenciais de saúde de indivíduos e grupos sociais de forma articulada às demais políticas e tecnologias de intervenção social que contribuem para a construção de ações que possibilitam responder às novas necessidades sociais em saúde (PEREIRA, 2001; BRASIL, 2006).

Nessa direção, a publicação da Política de Nacional de Promoção da Saúde (PNPS) reitera a importância da determinação social do processo saúde-doença e a necessidade de mudança do modelo assistencial em saúde brasileiro:

"Propõe-se, então, que as intervenções em saúde, ampliem seu escopo,
tomando como objeto os problemas e necessidades de saúde e seus
determinantes e condicionantes de modo que a organização da atenção e do
cuidado envolva, ao mesmo tempo, as ações e serviços que operem sobre os
efeitos do adoecer e àqueles que visem o espaço para além dos muros das
unidades e do sistema de saúde, incidindo sobre as condições de vida e
favorecendo a ampliação de escolhas saudáveis por parte dos sujeitos e
coletividades no território onde vivem e trabalham" (BRASIL, 2006, pág.
11).

Apesar de uma influência preventivista advinda da Estratégia global para a promoção da alimentação saudável, atividade física e saúde, publicado pela Organização Mundial da Saúde (OMS, 2003) - um documento inaugural que busca chamar a atenção para o problema do sedentarismo e da má alimentação, e fomentar a formulação e implantação de estratégias efetivas e integradas para a redução dos custos diretos e indiretos com a morbidade e a mortalidade relacionadas às doenças crônicas - a PNPS reforça o papel de alguns princípios de promoção de saúde, tal como o empoderamento, no processo de capacitação dos indivíduos e comunidades para assumirem maior controle sobre os fatores pessoais, socioeconômicos e ambientais que afetam sua saúde (BRASIL, 2006).

Além do empoderamento, outros princípios de promoção da saúde reconhecidos pela Organização Mundial da Saúde e ratificados pela PNPS revisada em 2014 são: concepção holística, intersetorialidade, participação social, equidade, ações multi-estratégicas e sustentabilidade (BRASIL, 2014; BRASIL, 2015; SICOLI; NASCIMENTO, 2003). Tem-se ainda que a disseminação da informação e a educação em saúde são bases para a tomada de 
decisão e componentes importantes da promoção de saúde (OMS, 1996; OMS, 1998). Nessa perspectiva de mudança de paradigma em saúde, é mister reconhecer a importância finalística do processo de formação e atuação profissional, inexoravelmente atrelado ao potencial de vida e saúde das pessoas e coletividades (DEVIDE, 2003). Restringir a formação de profissionais ao modelo biomédico hegemônico pode resultar em uma distância cada vez maior entre os profissionais da saúde e a realidade social em saúde (ROCHA; CENTURIÃO, 2007). Os cursos da área da saúde precisam reconhecer que o modelo biomédico não é capaz de sozinho modificar os condicionantes e determinantes mais amplos do processo e, por isso, devem incorporar o conceito de promoção da saúde que considera o fenômeno saúde/doença como um resultado dos modos de organização da produção, do trabalho e da sociedade em determinado contexto histórico (MINAYO, 2006).

Como a maior parte da formação dos profissionais de saúde ocorre em universidades, julgamos interessante refletir sobre a situação e a percepção de saúde dos professores universitários que atuam em grandes áreas da saúde, em particular os professores de educação física, reconhecendo o ambiente universitário como um espaço estratégico para promover a formação e a saúde da comunidade universitária e da população em geral (MELLO; MOYSÉS; MOYSÉS, 2009). Para tanto, é fundamental conhecermos um pouco mais sobre as universidades e seu potencial para promover uma vida mais saudável nas esferas coletiva e individual.

\subsection{A Universidade promotora (ou não) da saúde}

As universidades são um lócus privilegiado de vivências e experiências para toda a comunidade universitária. Nesse sentido, podemos reconhecer seu potencial para contribuir com a saúde em três áreas distintas: i) criando ambientes de trabalho, aprendizagem e vivências saudáveis para estudantes, professores e funcionários; ii) ampliando a importância da saúde, da promoção da saúde e da saúde coletiva no ensino, na pesquisa e na extensão; e iii) desenvolvendo alianças e parcerias para a promoção da saúde e a atuação comunitária, em toda sua abrangência, por meio de suas políticas e práticas empregadas (MEDA et al., 2008; MELLO; MOYSÉS; MOYSÉS, 2009; SILVA; BRITO, 2014).

Sobre esses aspectos, nos interessa refletir sobre o papel das universidades enquanto espaços sociais estratégicos que podem contribuir de forma potencial à saúde de grupos populacionais específicos a elas relacionados (alunos, professores e funcionários), com consequente impacto sobre a população geral. Promover a saúde, seja no âmbito acadêmico, 
seja nos serviços, implica proporcionar à população as condições necessárias para melhorar e exercer controle sobre sua saúde (MELLO; MOYSÉS; MOYSÉS, 2009). Antevemos aí dois aspectos fundamentais à nossa discussão: as condições de trabalho (e estudo) da universidade tais como ambiente natural e físico, materiais e equipamentos e suporte organizacional, dentre outros; e as concepções de saúde que orientam as práticas individuais, profissionais e institucionais.

As condições ambientais, culturais e econômicas influenciam diretamente na qualidade de vida e a saúde da comunidade e seus membros (BUSS, 2000). No entanto, é essencial que as organizações e os indivíduos assumam seu papel na criação de ambientes, oportunidades e escolhas saudáveis, mediante o comprometimento ético-político com o desenvolvimento sustentável e a redução das desigualdades em saúde (MOYSÉS; MOYSÉS; KREMPEL, 2004; SÍCOLI; NASCIMENTO, 2003).

São as concepções e os interesses dos cidadãos que devem orientar o ordenamento das instituições sociais. Assim, os processos de mudanças vão se tornando mais complexos na medida em que as diferentes experiências se materializam para além dos discursos e possibilitam uma compreensão mais abrangente e sistemática sobre a natureza da mudança (MELLO; MOYSÉS; MOYSÉS, 2009). As Instituições de Ensino Superior, espaços de formação acadêmica e cidadã, se constituem como cenário indicado para levar a cabo a formação integral dos sujeitos, através de uma gestão baseada nos princípios do desenvolvimento humano sustentável, desde o ponto vista humanista, científico e tecnológico (SILVA; BRITO, 2014).

É nessa perspectiva que surge o conceito de Universidades Promotoras de Saúde, com seu marco conceitual (Figura 2) indicando a estrutura que sustenta diversas ações de promoção de saúde (LANGE; VIO, 2006). 


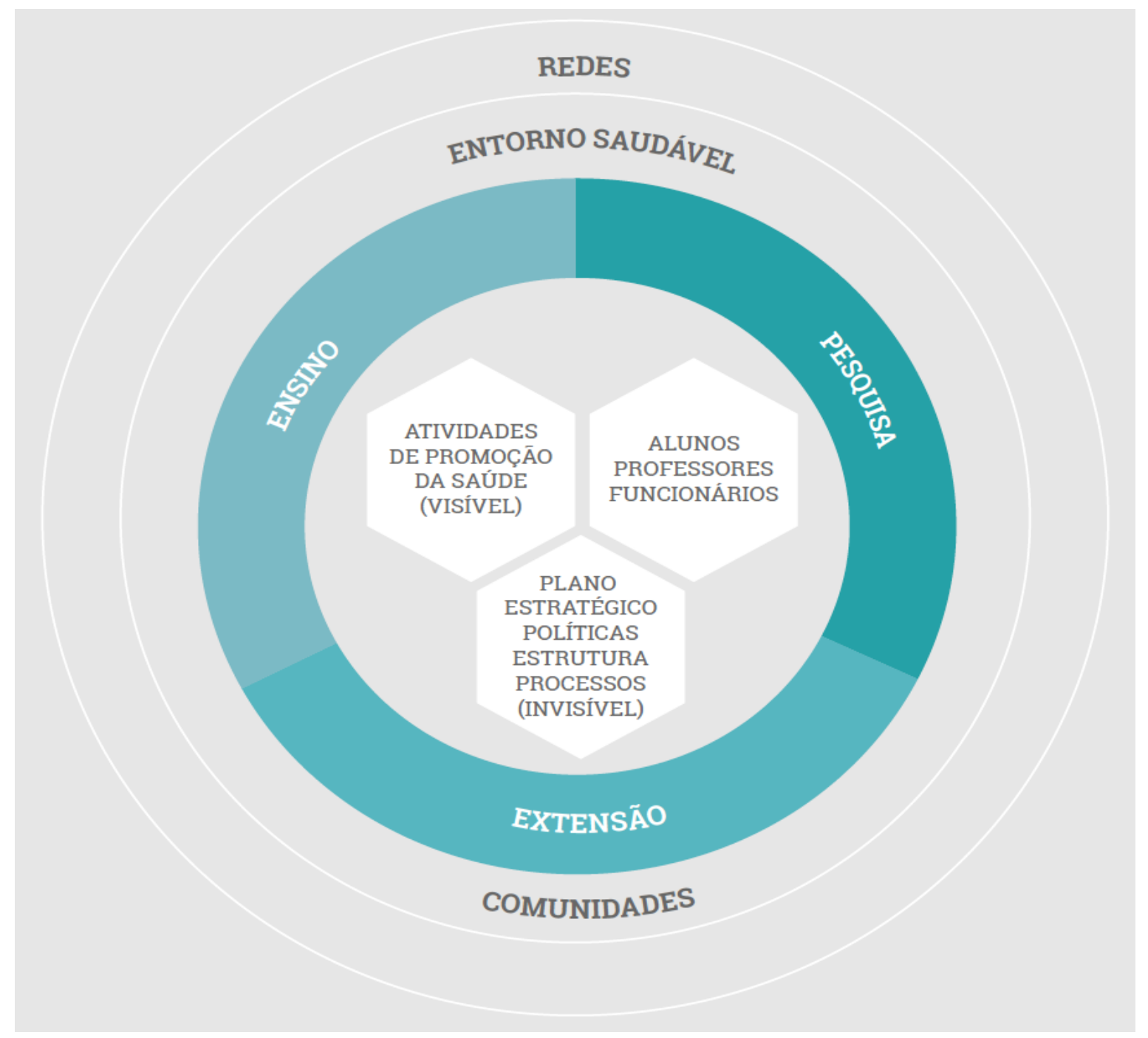

Figura 2. Marco conceitual das Universidades Saudáveis. (Adaptado pela autora a partir de LANGE; VIO, 2006).

Quanto aos conceitos que orientam a formação e a atuação em saúde há relativo consenso quanto à hegemonia da abordagem biologicista, medicalizante, com ênfase no conhecimento experimental de base clínica e laboratorial que reforçam a separação entre individual e coletivo, privado e público, biológico e social, curativo e preventivo (PAIM; ALMEIDA FILHO, 1998). O modelo pedagógico é tecnicista e conteudista, organizado de maneira compartimentada e isolada, que fragmenta os indivíduos e os fenômenos em partes estanques, e adota sistemas de avaliação cognitiva por acumulação de informação técnicocientífica padronizada que incentivam a especialização precoce. Tais aspectos centram as oportunidades de aprendizagem na clínica perpetuando modelos tradicionais de prática em saúde e dificultam a concepção ampliada de promoção da saúde (MELLO; MOYSÉS; MOYSÉS, 2009). 
Desta forma, o trabalho desenvolvido nas universidades brasileiras não enseja a formação crítica em saúde dificultando que se atinja uma organização moderna da prática em saúde. Essa seria necessariamente interativa, com profissionais de várias carreiras e níveis de escolaridade partilhando espaços de iniciativa e de corresponsabilização, com utilização de suas aptidões intelectuais e afetivas, com coordenação de tarefas, comunicação interna e externa, e intercâmbios de informações (MELLO; MOYSÉS; MOYSÉS, 2009).

Ao falar sobre Universidades Promotoras de Saúde, é imperativo que se reflita sobre os referenciais teóricos adotados e o contexto de trabalho dos docentes dos cursos da grande área da saúde. Isso porque são atores chave na produção de saberes e práticas e na formação dos profissionais de saúde. Independente da disciplina que ministram, professores representam um importante canal de comunicação e informação para os alunos, pois estão envolvidos na realidade social, apresentam similaridade comunicativa e servem de referência nos conhecimentos e comportamentos (BORGES et al., 2009; DE OLIVEIRA, 2010; DOYLE; FELDMAN, 1994).

\subsection{O contexto de trabalho dos docentes universitários}

A despeito do papel chave dos docentes na construção de uma Universidade Promotora de Saúde, o contexto de trabalho atual não é favorável a esse envolvimento. O ritmo acelerado que perpassa as relações de trabalho contemporâneas podem levar o trabalhador a participar de uma corrida contra o tempo para realizar as tarefas que lhes são imputadas, as quais se tornam, consequentemente, parte da sua responsabilidade (LA FALCE; GARCIA; MUYLDER, 2011). O excesso de tarefas e responsabilidades advindas da atuação no tripé universitário (ensino, pesquisa e extensão) e ainda nas atividades administrativas e financeiras que se acumulam na sua carga de atividades tem levado alguns docentes a apresentar dificuldades em cumprir com as exigências (MELLO; MOYSÉS; MOYSÉS, 2009), gerando uma sobrecarga física e psíquica, e levando os professores ao esgotamento, ao sofrimento e ao adoecimento (FERREIRA, 2011; FONTANA; PINHEIRO, 2010; SERVILHA; ARBACH 2011).

O trabalho prescrito advém de um conjunto de condições e exigências a partir das quais o trabalho deve ser realizado; dimensão determinada pelas condições de trabalho, pelo ambiente físico e por condições socioeconômicas, entre outros fatores, que se somam às prescrições compostas por normas, metas, procedimentos técnicos, e outros (TELLES; ALVAREZ, 2004). Por outro lado, o trabalho real é o colocado em ação pelo trabalhador; é o 
que realmente acontece em seus locais de trabalho (TRINQUET, 2010). A tensão das escolhas ocorre no espaço entre o trabalho prescrito e o trabalho real, "que coloca em cena não só os saberes mobilizados na produção, mas também a relação que cada trabalhador estabelece com esses saberes e, logo, a sua subjetividade” (SANTOS, 1997, pág. 14).

As transformações recentes nas esferas política, econômica, cultural e tecnológica vêm afetando profundamente as formas de organização e o cotidiano do trabalho no sistema educacional (FONTANA; PINHEIRO, 2010). Na última década, políticas federais como o Programa de Reestruturação e Expansão das Universidades Federais (REUNI), instituído em 2007, e o Plano Nacional de Pós-Graduação para 2011 a 2020, da Coordenação de Aperfeiçoamento de Pessoal de Nível Superior (CAPES), apesar de contribuir valorosamente para a expansão e ampliação do acesso à educação superior e à pesquisa no Brasil (BRASIL, 2003; CAPES, 2015), também agravaram a lógica de produção empresarial e a precarização do trabalho docente (GUARANY, 2012).

As mesmas políticas públicas que induzem o processo de universalização do acesso à educação intensificam as exigências de metas por geração de conhecimentos, formação profissional de qualidade e produção de novas tecnologias para o país (FERNANDES, 1996; COUTINHO; MAGRO; BUDDE, 2011; MANCEBO; ROCHA 2002).

Ao incentivar o docente de Instituições de Ensino Superior a produzir, vinculando parte do seu salário ao alcance de metas, essas políticas estimulam a adoção de uma postura produtivista. O que antes era consequência de um trabalho (produção de artigos e divulgação de dados de pesquisas) passa a ser um fim, assumindo o valor de troca e não mais de uso (GUARANY, 2012). Não obstante, por se referirem ao processo intelectual, investigativo e criativo, que não se encaixa na lógica produtivista, as tarefas inerentes ao trabalho docente passam a funcionar como estressores, gerando sobrecarga e sofrimento (GARCIA; OLIVEIRA; BARROS, 2008).

Em adição, a conjuntura de crise econômica, política e cultural vivida no país coloca em espera a continuidade dos planos de reestruturação e fortalecimento da educação e da ciência, intensificando a disputa pelos recursos escasseados (MACHADO, 2016). A exacerbação da competitividade adiciona tensão à já extensa lista de demandas (no ensino, pesquisa, extensão e administração, somadas às atividades de planejamento e produção de conteúdo, além da negociação e estabelecimento de vínculos) desempenhadas pelos docentes de IES (OLIVEIRA, et al., 2012) 
Outro aspecto de grande relevância, a revolução tecnológica na educação produziu, apesar de diversos efeitos positivos, a falta de barreiras entre o tempo de trabalho e o tempo de descanso. Por exemplo, a alteração na Consolidação das Leis do trabalho com a aprovação da lei 12.551, em dezembro de 2011, que regulamenta o uso de tecnologias pelo trabalhador de forma remota, ou seja, em casa ou à distância usando computadores, telefones, celulares e smartphones, indicando que estas devem ser computadas como horas de trabalho, o que em geral não ocorre (GOMES; CAETANO, 2014).

As mudanças tecnológicas tanto proporcionam quanto demandam dos profissionais imediatismo resolutivo e atualizações constantes, afetando o ritmo e a capacidade de assimilação das tarefas. Em geral, o professor apela a esforços extras para atualizar conhecimentos e instrumentalizar-se nas novas tecnologias que suas funções didáticas e pedagógicas requerem, cumprindo uma jornada que excede aquela presumida em seu contrato de trabalho (LIMA; FILHO, 2009). Essas inovações também aumentam os dispositivos de controle que enfatizam ligações funcionais e pragmáticas dos trabalhadores no seu cotidiano (MANCEBO; ROCHA, 2002).

Além disso, para o docente, as atividades intra ou extraclasse produzem demandas físicas e psicológicas por envolvem longos períodos em pé (ministrando aulas), sentado (orientando, escrevendo e corrigindo), transportando livros e laptops (em geral em mochilas não adequadas à postura), além do elevado esforço mental demandado para as exigências cognitivas (LEMOS 2005).

No caso de professores universitários que atuam na grande área da saúde seu trabalho, além de atender às questões científicas, educacionais e de formação profissional, deve estar voltado às necessidades de saúde da população local, sendo necessário aliar o conhecimento técnico ao fazer pedagógico (PERIM et al., 2009). No entanto, essa exigência pode produzir um paradoxo: mesmo sendo autoridade científica na área, o profissional pode não conseguir "promover a saúde" de forma satisfatória ou em conformidade com as recomendações que ensina (GUBA; LINCOLN, 2011; JUNG, 1989).

Não obstante, é importante destacar que o trabalho pode também representar fonte de prazer e realização pessoal (LAURELL; NORIEGA, 1980). Os obstáculos estimulam professores a criar estratégias para driblar as dificuldades cotidianas e as condições deficitárias de trabalho e a elaborar outras normas e regras que redefinem a técnica, encontrando modos de regulação que deem conta da variabilidade inerente à sua atividade. Assim emerge o trabalho real, que afirma a potência dos seres vivos de reorganizarem 
cotidianamente suas demandas (DEJOURS, 1999). O vínculo, um dos elementos básicos do processo de aproximação e interesse pela vida social, pode ser um elemento importante para enfrentar as adversidades e suportar os níveis de estresse, angústia e de falta de sentido no trabalho (GARCIA; OLIVEIRA; BARROS, 2008).

Outras vivências de prazer no trabalho foram associadas à identidade de ser professor, especialmente o reconhecimento do trabalho, a produção de conhecimento e o impacto social que suas atividades promovem, além da ampla possibilidade de interações e de fortalecimento dos laços afetivos do convívio social (COUTINHO; MAGRO; BUDDE, 2011; GARCIA; OLIVEIRA; BARROS, 2008; GONÇALVES; PIRES, 2015; SILVÉRIO, et al., 2010). Interações entre professor, aluno e população (incluindo demonstrações de respeito e reconhecimento do trabalho, troca de conhecimentos e afetividades) promovem realização pessoal e profissional (COUTINHO; MAGRO; BUDDE, 2011; SILVÉRIO, et al., 2010). Nesse sentido, a valorização e o respeito por parte de gestores, alunos e comunidade podem contribuir para a promoção da saúde dos docentes das IES (FONTANA; PINHEIRO, 2010).

Assim, a relações entre os processos de saúde e doença dos professores universitários com seu contexto de trabalho implica analisar os modelos de gestão implementados nas IES do país e deve ser entendido como um fenômeno sistêmico complexo: cada vez que um dos componentes sofre uma alteração, esta repercute e atinge os demais fatores, desencadeando um processo para buscar um novo equilíbrio do sistema (DEJOURS, 1999; GARCIA; OLIVEIRA; BARROS, 2008; ULRICH, 2005).

No contexto do trabalho, diversas variáveis tais como: pressão do tempo advinda de excessivas metas de produtividade e demandas por cursos e atualizações; conflitos nas relações hierárquicas; ausência de autonomia decisória; dificuldades de contato com colegas durante a jornada de trabalho; e ambiente desfavorável (FONTANA; PINHEIRO, 2010); podem ser agrupadas em três dimensões interdependentes: Organização do Trabalho; Relações Sócioprofissionais; e Condições de Trabalho (Figura 3). Esse referencial teórico constitui os alicerces de um dos instrumentos de avaliação utilizados no presente estudo: a Escala de Avaliação do Contexto de Trabalho (FACAS, 2013; MENDES; FERREIRA, 2008). 


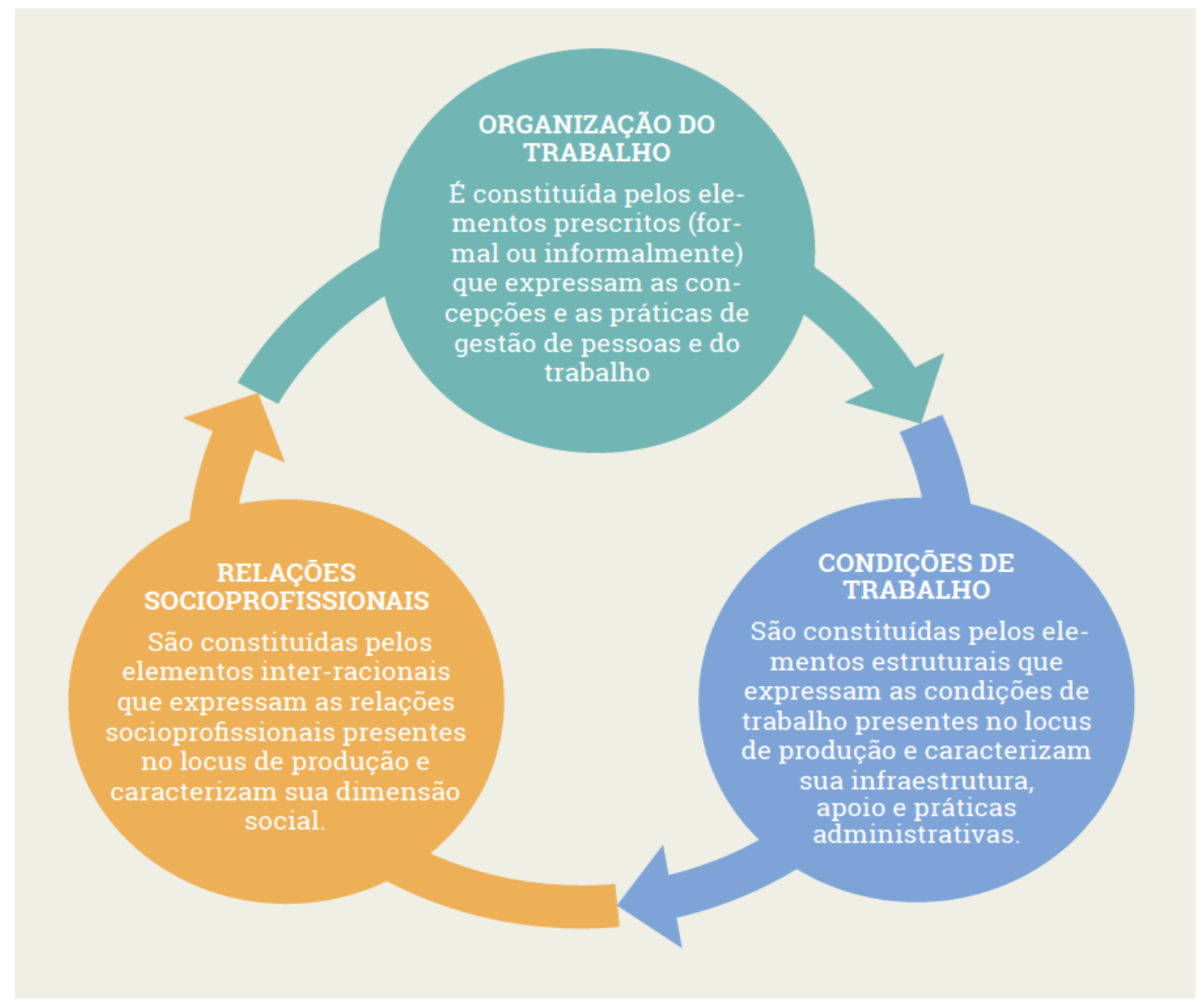

Figura 3. Dimensões interdependentes que compõem a Escala de Avaliação do Contexto de Trabalho. (Adaptado de MENDES; FERREIRA, 2008).

\section{$2.4 \mathrm{O}$ autocuidado apoiado (institucional) e a prática do cuidar de si}

O autocuidado apoiado se refere ao uso de estratégias institucionais de apoio para guiar o autocuidado, uma estratégia que se caracteriza por focalizar o papel das pessoas no gerenciamento de sua própria saúde. Não se trata de prescrever ou dizer às pessoas o que devem fazer, mas de reconhecer o papel delas na priorização e definição do que fazer para gerenciar e manter sua saúde, a partir de recursos existentes no contexto de trabalho (MENDES, 2012).

É um modelo de manejo da situação de saúde que se tornou bastante atrativo a partir do crescimento exponencial das doenças crônicas e do envelhecimento populacional. Suas técnicas podem incluir: avaliação e monitoramento de dados de saúde, técnicas de resolução de problemas, pactuação de plano de metas e autocuidado, e mobilização de recursos (físicos e sociais) para prover o apoio necessário ao autocuidado (MENDES, 2012). Para facilitar o 
desenvolvimento de comportamentos de autocuidado é necessária organização, disponibilidade e acessibilidade aos cuidados de saúde e a outros equipamentos sociais (SILVA; BRITO, 2014).

Embora técnicas e métodos de apoio ao autocuidado precisem ser construídos e validados com base em evidências científicas de modo que possam constituir um arcabouço de estratégias, de suporte social e de informações adequados para que as pessoas convivam com suas condições de saúde e se mantenham ativas, com qualidade de vida e bem estar no desempenho de seus papéis sociais (MENDES, 2012), destacamos o uso de questionários que visam identificar o apoio institucional à saúde como um ponto exploratório sobre o tema.

No presente estudo optamos por utilizar o Cartão de Pontuação do Apoio à Saúde no Local de Trabalho (ANEXO I, com a pontuação), desenvolvido originalmente pelo Center for Disease Control de Atlanta, USA (CDC, 2012) com o nome de Worksite HealthCard, traduzido, adaptado e validado por Soárez e Ciconelli (2013) com 12 seçõestema. Esse questionário visa ajudar na avaliação do quanto as instituições tem implementado intervenções de apoio que visem promover a saúde baseadas em evidências do local de trabalho, identificar lacunas e priorizar intervenções de alto impacto (ROEMER et al., 2013; CDC, 2012). Em concordância com os objetivos da presente pesquisa, optamos por utilizar apenas três seções-tema que contemplam as dimensões do apoio organizacional à promoção da saúde; à atividade física; e ao gerenciamento do estresse (Figura 4).

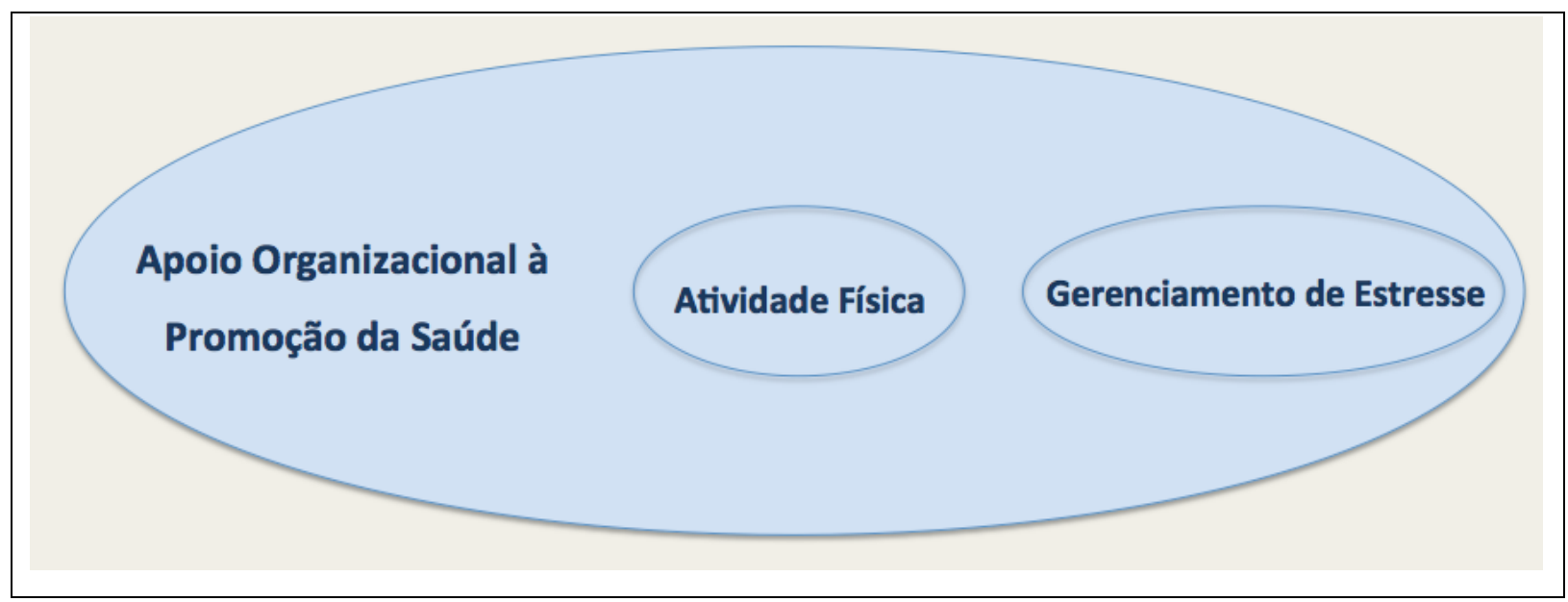

Figura 4. Os três componentes do Cartão de Pontuação do Apoio à Saúde no Local de Trabalho utilizados para avaliar a Universidade de Brasília.

O autocuidado apoiado visa promover o cuidado de si ao gerar condições que favoreçam o empoderamento de grupos e indivíduos para auto gerenciarem sua saúde, 
estimulando ações voluntárias e intencionais que os indivíduos realizam de forma deliberada em seu próprio benefício, para promover e manter a sua saúde ou para prevenir e lidar com a doença, reconhecendo a influencia direta e objetiva do ambiente (físico e social) nessas ações (DIÓGENES; PAGLIUCA, 2003; OMS, 1998). As ações incluem tomada de decisões e capacidade de se engajar, e têm o propósito de contribuir de forma específica para a manutenção da integridade estrutural, do funcionamento e do desenvolvimento humanos, da saúde, do bem-estar, e da vida (BUB, et al. 2006).

O cuidado de si mesmo (apoiado ou não) é um dos aspectos do viver saudável e consiste na realização de ações dirigidas a si mesmo e ao ambiente, a fim de regular o funcionamento de ambos, segundo seu interesse na vida e no bem-estar (OREM, 1991). A atividade do cuidar de si não constitui um exercício de solidão, mas uma verdadeira prática social. Para cuidar de si, o ser humano não pode ser reduzido à dimensão biológica, pois é fruto de um processo e de relações sociais e ambientais bem mais amplas e abrangentes (ASSUMPÇÃO; MORAIS; FONTOURA, 2002).

Nessa perspectiva, o cuidar de si mantém estreita relação com os princípios de Promoção da Saúde. No entanto, é interessante destacar que esse cuidado em geral é valorizado e percebido como essencial a partir do momento em que o indivíduo toma consciência de um processo de adoecimento, refletindo sobre seu estilo de vida, seus hábitos, e os determinantes desses processos. No dia a dia, quando se encontram bem e saudáveis, as pessoas não dão a devida importância ao constante exercício do cuidar de si (SILVA; OLIVEIRA; SILVA, et al., 2009).

Em adição, o cuidar de si não é uma prática específica relativa a uma formação acadêmica, pois todo e qualquer indivíduo deveria se preocupar e ser capaz de cuidar de si. No entanto, ponderar sobre esse processo em docentes de cursos superiores da área da saúde faz um questionamento peculiar emergir: "um profissional da saúde, se não estiver disponível para cuidar de si, terá condições de cuidar do outro?"; nos aproximando das reflexões de Jung (1989) sobre "o curador adoecido".

Ao assumirmos que o objeto de estudo e prática da educação física em saúde é a produção relacional educativa e cuidadora para com a defesa e a afirmação da vida em sua expressão corporal - o corpo em ato de invenção da vida e da definição de nós mesmos (CECCIM; BILIBIO, 2007) - identificamos a saúde como uma das resultantes desse processo. Nos processos amplos e complexos produtores de saúde temos particular interesse em 
compreender como os docentes do curso de Educação Física percebem as práticas corporais e atividades físicas na perspectiva do autocuidado apoiado e do cuidado de si.

\subsection{As práticas corporais e atividades físicas como cuidado de si}

As práticas corporais e as atividades físicas, se forem realizadas regularmente de forma voluntária, intencional e prazerosa, podem efetivamente promover a saúde, representando um ótimo ponto de partida para o cuidar de si (ARAÚJO; ARAÚJO, 2000; GOMES; BRAUNER, 2006). Pesquisas científicas mostram que índices de saúde estão associados ao estilo de vida das pessoas; que a mortalidade precoce é menos comum entre pessoas que incluem na sua rotina práticas saudáveis; e que a atividade física regular pode gerar benefícios biopsicossociais à saúde (ARAÚJO; ARAÚJO, 2000; BRACHT, 2011; DEMARCO; SIDNEY, 1989; NAHAS; BARROS; FONSECA, 2004; NAHAS, et al., 2009).

No entanto, para se configurar como uma atividade de cuidado promotor de saúde é fundamental que sua prática parta de sujeitos empoderados, superando a dimensão prescritiva, e que seus benefícios não sejam reduzidos à dimensão biológica do ser humano (ASSUMPÇÃO; MORAIS; FONTOURA, 2002; DIÓGENES; PAGLIUCA, 2003). É importante reconhecer que indicadores biológicos ou epidemiológicos são importantes, mas insuficientes para explicar essas relações com a saúde e a qualidade de vida, conforme aponta Araújo e Araújo (2000; pág. 195):

“...quando falamos na relação entre a atividade física e a qualidade de vida, precisamos estar conscientes de que essa relação pode ser negativa, seja pela ausência de resultados positivos para a saúde, seja pela ausência de atividade física ou também por efeitos deletérios que a atividade física pode causar à saúde e consequentemente à qualidade de vida do cidadão. Quando ampliamos os efeitos de uma vida ativa fisicamente para além da saúde e colocamos os efeitos do exercício, adequadamente realizado, como fator indispensável para a melhoria na qualidade de vida de um dado indivíduo, aí estamos partindo da premissa de que alguém inativo e sedentário não tem boa qualidade de vida. Contudo, a classificação de uma qualidade de vida boa ou ruim está diretamente relacionada à maneira do indivíduo entender $\mathrm{o}$ sentido da vida."

Ao identificar que grande parte dos referenciais teóricos sobre a relação das práticas corporais e atividades físicas com a promoção da saúde é centrada numa compreensão estatística de benefícios fisiológicos à saúde individual, em geral expressos por alguma 
medida de aptidão física (ACSM, 2007; BRASIL, 2014; CASPERSEN; POWEL; CHRISTENSON, 1985; OMS, 2004), faz-se necessário considerar as concepções vigentes de saúde, de práticas corporais e de atividades físicas que embasam a produção de conhecimentos e saberes nessa área (CARVALHO; NOGUEIRA, 2016).

No campo científico da Educação Física, o termo "atividade física" é usualmente utilizado para designar "qualquer movimento corporal produzido pelos músculos esqueléticos, que resulte em gasto energético maior que os níveis de repouso" (CASPERSEN; POWEL; CHRISTENSON, 1985), estando claramente associado a parâmetros biológicos de saúde (ASSUMPÇÃO; MORAIS; FONTOURA, 2002). Com o aumento dos estudos epidemiológicos que apontam o sedentarismo como fator de risco no processo de adoecimento moderno (transição epidemiológica), marcado pela pandemia de doenças crônicas não transmissíveis (CARVALHO, 2007; OPAS, 2005), o uso desse termo ganha destaque como estilo de vida desejável (CECCIM; BILIBIO, 2007).

Por outro lado, o termo "práticas corporais" vem sendo valorizado pelos pesquisadores que estabelecem relação com as ciências humanas e sociais, referindo-se ao se movimentar como uma forma de comunicação, constituinte e construtora de cultura; como uma construção histórica, não uma dimensão inerte da realidade (SILVA; PINHEIRO, 2013). São diferentes formas de atividade corporal com ligações culturais, tais como: atividades de lazer, artes, recreação, danças, jogos, lutas, atividades circenses, dentre outras (LAZZAROTTI FILHO et. al., 2010).

Estabelecer essa distinção epistemológica não significa negar os benefícios fisiológicos das atividades físicas, mas sim conferir destaque às contribuições das práticas corporais no favorecimento do empoderamento, da autonomia e da equidade no acesso e na produção do cuidado e de modos de vida saudáveis, incentivando a melhoria dos espaços públicos, considerando a cultura local, e incorporando brincadeiras, jogos, danças e lutas populares, dentre outras práticas, para efetivamente promover a saúde e a qualidade de vida da população (CARVALHO; NOGUEIRA, 2016; LAZZAROTTI FILHO et. al., 2010; OMS, 1986;).

Nesse sentido, ainda é um desafio para o campo da Educação Física o desenvolvimento das práticas corporais como cuidado de si fundamentado em uma concepção de promoção da saúde apoiada em processos que vão além da repetição de conhecimentos; e que estejam centrados no fortalecimento da identidade dos sujeitos e na incorporação de 
soluções criativas e saberes saudáveis para o enfrentamento dos obstáculos a uma vida ativa (MORETTI, et al., 2009).

Ao reconhecer a relação das práticas corporais com a promoção da saúde é importante considerá-las como fenômenos que apresentam conexão com o território onde os indivíduos vivem; com os espaços de convivência e construção humana; com a família e os grupos comunitários; com os espaços de decisões políticas; com as estruturas e os equipamentos públicos; com o trabalho; e com muitas outras relações intersetoriais (BUSS; PELLEGRINI FILHO, 2007).

Assim, mesmo na perspectiva do autocuidado, é necessário superar a ênfase hegemônica da relação entre atividade física e saúde centrada exclusivamente na responsabilização individual. É preciso considerar que diversos determinantes e condicionantes sociais, econômicos, culturais, ambientais e políticos (FERREIRA, 2001; NOGUEIRA, 2014) podem apoiar ou dificultar a adoção de comportamentos ativos e saudáveis. É fundamental também que o sujeito tenha autonomia e empoderamento para participar socialmente da modificação desses determinantes de forma a torná-los mais promotores de saúde (BUSS; CARVALHO, 2009).

Concebendo o campo acadêmico-científico como espaço constitutivo da produção de distintos domínios, conhecimentos e saberes, bem como um lócus importante da formação humana e profissional, que responde a um ordenamento institucional complexo composto por forças políticas dinâmicas (BOSI; PRADO, 2011); e admitindo que o campo da Educação Física esteja em constante debate acerca dos conceitos com os quais opera e com os quais expressam os significantes que problematiza (LAZZAROTTI FILHO et. al., 2010); julgamos fundamental conhecer os sentidos e significados atribuídos às praticas corporais, atividades físicas e Promoção da Saúde pelos docentes desse campo.

Em geral os cursos superiores em Educação Física vêm formando profissionais de saúde com a concepção vigente e hegemônica que associa as práticas corporais e as atividades físicas como meio de prevenção e controle de doenças (CARVALHO, 2007). Buscaremos identificar essas concepções a partir dos docentes de uma Faculdade de Educação Física estabelecida numa Universidade Pública Federal localizada na região Centro-Oeste do país: a Universidade de Brasília (UnB). 


\section{CENÁRIO DA PESQUISA}

\subsection{O Contexto da Universidade de Brasília no Distrito Federal}

A UnB se situa no Distrito Federal (DF), uma unidade atípica na federação (não é estado e nem possui municípios) estabelecida dentro do Estado de Goiás. O DF é um território autônomo de $5780 \mathrm{~km}^{2}$, atualmente dividido em 31 Regiões Administrativas (Figura 5).

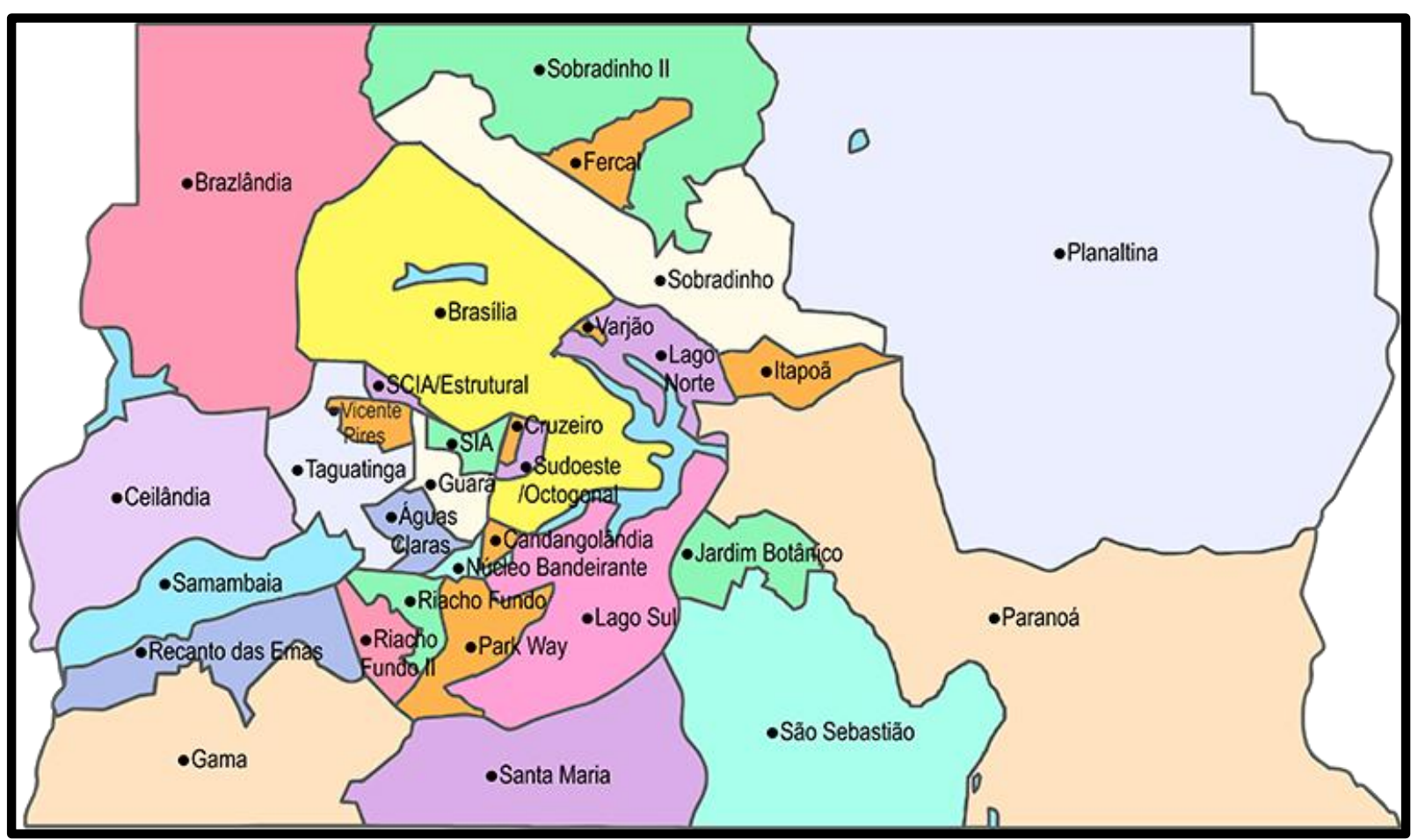

Figura 5. O Distrito Federal e suas 31 Regiões Administrativas. Fonte: Brasília, 2016.

Originalmente, a constituição do DF tem início com a construção da cidade de Brasília, impulsionada por Juscelino Kubitschek visando mudar a capital do Rio de Janeiro para o centro do país. Foram palavras do então presidente da república:

"Deste planalto central, desta solidão que em breve se transformará em cérebro das altas decisões nacionais, lanço os olhos sobre o amanhã do meu país e antevejo esta alvorada com fé inquebrantável e uma confiança sem limites no seu grande destino." (JUSCELINO KUBITSCHEK, 1956).

Planejada integralmente desde o início através de um projeto inovador de Lúcio Costa na forma de cruz (um Plano Piloto), Brasília foi pensada com áreas específicas para cada tipo 
de uso: residencial, administrativo, comercial, industrial, recreativo, cultural, e assim por diante.

\begin{abstract}
"Brasília deve ser concebida não como um simples organismo capaz de preencher satisfatoriamente, sem esforço, as funções vitais próprias de uma cidade moderna qualquer, não apenas como urbs, mas como civitas, possuidora dos atributos inerentes a uma Capital." (LÚCIO COSTA, 1956).
\end{abstract}

A construção de Brasília - inaugurada incompleta em 21 de abril de 1960 - foi marcada por intensos processos migratórios de operários vindos de vários pontos do Brasil, os candangos, especialmente nordestinos. A quantidade de operários afluindo às obras fez nascer vários povoados no entorno, principalmente na Cidade Livre, depois chamada Núcleo Bandeirante. O Plano Piloto previa a criação de cidades-satélites para a acomodação da população excedente, e os vários acampamentos irregulares no entorno se tornaram cidades permanentes, como Brazlândia, Candangolândia, Paranoá e Planaltina (MORELLI, 2002).

Com o processo de expansão e a transferência dos principais órgãos da administração federal para a nova capital, o DF ganha suas primeiras subprefeituras: Planaltina, Taguatinga, Sobradinho, Gama, Paranoá, Brazlândia e Núcleo Bandeirante; substituídas, em 1964, por Regiões Administrativas. Em 1989 foram incluídas quatro novas regiões (Ceilândia, Guará, Cruzeiro e Samambaia); em 1993, mais quatro (Santa Maria, São Sebastião, Recanto das Emas e Riacho Fundo); e em 1994 (Lago Sul, Lago Norte e Candangolândia). As demais regiões (Águas Claras, Riacho Fundo II, Sudoeste, Octogonal, Varjão, Park Way, SCIA, Sobradinho II, Jardim Botânico, Itapoã, SIA, Vicente Pires e Fecal) tiveram suas subprefeituras inauguradas após 1995 (BRASÍLIA, 2016).

Atualmente, em consequência dos processos de ordenamento de seu território e da intensa expansão da urbanização para a periferia limítrofe, hoje a Região Integrada de Desenvolvimento do DF e Entorno compreende também os municípios goianos de Abadiânia, Água Fria de Goiás, Águas Lindas de Goiás, Alexânia, Cabeceiras, Cidade Ocidental, Cocalzinho de Goiás, Corumbá de Goiás, Cristalina, Formosa, Luziânia, Novo Gama, Padre Bernardo, Pirenópolis, Planaltina, Santo Antônio do Descoberto, Valparaíso de Goiás e Vila Boa, e os municípios mineiros de Buritis e Unaí (BRASÍLIA, 2016).

O DF hoje conta com aproximadamente três milhões de habitantes e, além de ser o centro político do país, é um importante centro econômico, sendo a sétima unidade federativa com o maior produto interno bruto do Brasil (IBGE, 2012); abrigando a maior proporção da população com rendimentos acima de cinco salários mínimos em comparação à população 
brasileira (PNAD, 2013). A economia do DF tem como principais bases à construção civil e o varejo, a agricultura e a pecuária, além das funções administrativas e de funcionalismo público desenvolvidas na capital federal (DF, 2010).

$\mathrm{Na}$ área educacional, o DF possui os melhores índices de escolaridade do país, com uma taxa de alfabetização de 95,8\% (CODEPLAN, 2013). Atualmente o DF conta com 61 IES, sendo 02 Universidades e 59 Faculdades Privadas (INEP, 2013). Não obstante, os índices de criminalidade no DF estão entre os maiores do Brasil, principalmente nas regiões do entorno, uma herança do crescimento desordenado, ainda que assentado em núcleos urbanos planejados (BRASÍLIA, 2016).

Importante destacar que as Regiões Administrativas refletem uma marcante desigualdade social entre si. O DF abriga pessoas muito ricas em seu centro e muito pobres na periferia, expondo uma das faces cruéis da exclusão social e da iniquidade (CODEPLAN, 2014). Essa delimitação territorial, que deixa clara a desigualdade quanto às classes sociais, gera uma condição insatisfatória quanto à Promoção da Saúde. Condições de trabalho e vida, incluindo transporte, saneamento, qualidade habitacional, engenharia urbana e disponibilidade ou acesso a alimentos e serviços básicos são completamente diferentes para a população mais rica e para os mais pobres.

Apesar de possuírem certa autonomia administrativa e de comércio local, as Regiões Administrativas dependem de Brasília para grande parte de suas atividades econômicas, sociais e de serviços públicos (BRASIL, 2010). Essa característica faz com que as diversas classes sociais convivam regularmente no mesmo espaço central, o Plano Piloto, em busca de serviços e de atividades que melhor remuneram e que configuram mais oportunidades (CODEPLAN, 2014).

O Plano Piloto (Brasília) possui o formato de um avião (Figura 6) que engloba a Asa Norte e a Asa Sul, o Eixo Monumental, a Esplanada dos Ministérios, Setor de Embaixadas Sul e Norte, e sediam o Governo do DF e os três poderes da República: Executivo, Legislativo e Judiciário. Já a Região Administrativa de Brasília é constituída pelo Plano Piloto acrescido da área do Parque Nacional e das regiões do Lago Norte e Sul. Brasília possui a maior renda per capita do Brasil e a melhor média nacional de alguns índices, tais como veículos e telefones por habitantes. Por exemplo, o Lago Sul possui aproximadamente $46 \%$ dos domicílios com renda per capita acima de 10 salários mínimos, uma renda média quatro vezes maior que a do DF e quase 18 vezes maior que a Região Administrativa da Estrutural (CODEPLAN, 2014). 
Com relação ao jeito de ser do brasiliense, há uma descrição que o caracteriza como um ser "fechado", restrito em seus contatos sociais. Algumas características urbanas da cidade podem favorecer essa tipificação, tais como a ausência de esquinas e as vias de circulação expressa que favorecem o uso de veículos privados e reduzem os contatos sociais cotidianos (BRANCO, 2006; TIBURRI, 2013). A pouca participação nos assuntos coletivos e na ocupação dos espaços urbanos reforça o individualismo inerente às grandes cidades, enfatizando o âmbito individual em detrimento do coletivo; projetando o indivíduo para seu mundo interior, da solidão e da reserva; desconstruindo o cidadão (BRANCO, 2006).

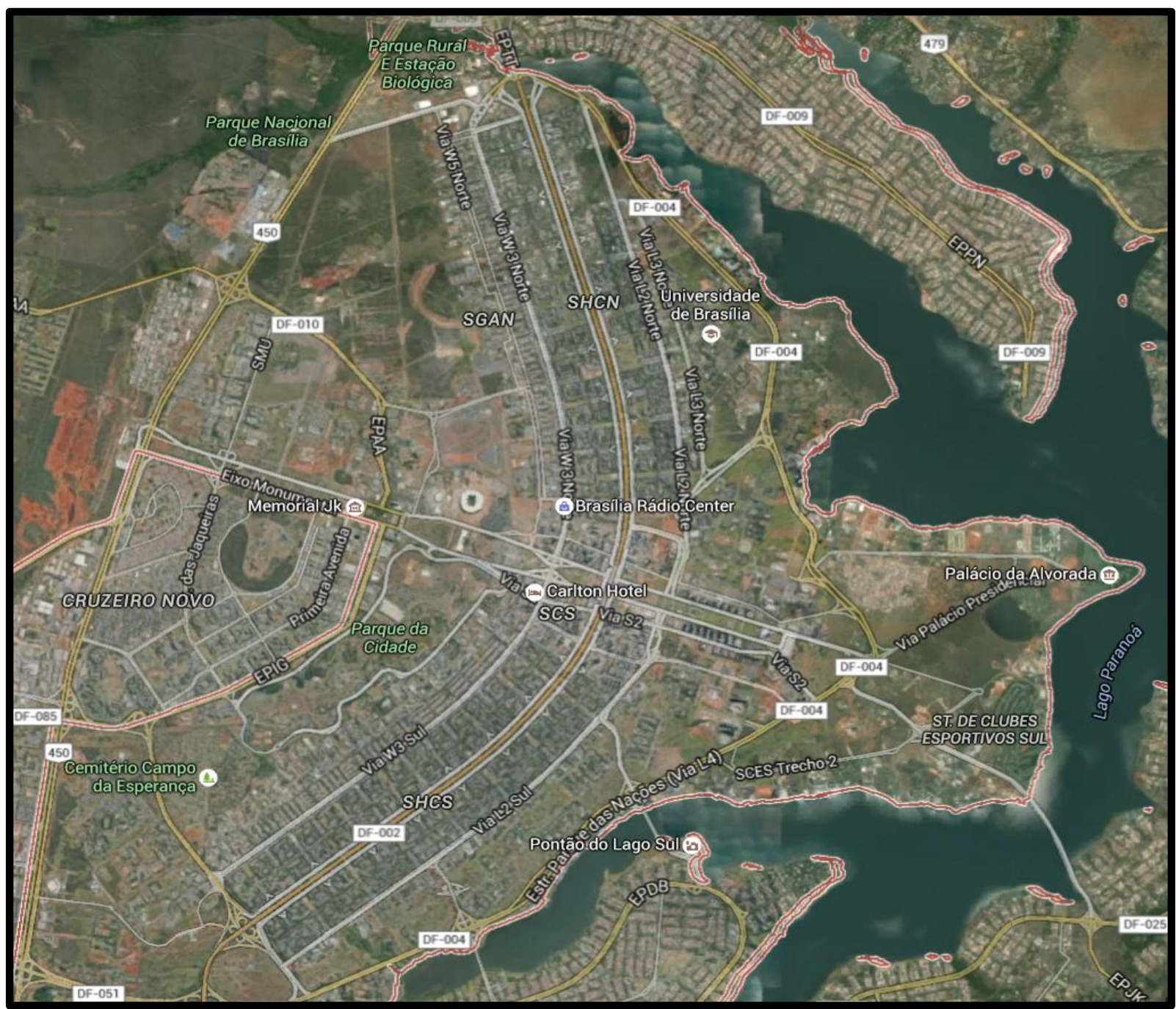

Figura 6. A Região Administrativa de Brasília com destaque para o Plano Piloto. Fonte: Google Maps (https://www.google.com.br/maps/). 
A UnB, principal universidade do Centro-Oeste, juntamente com as autarquias, os órgãos públicos e os ministérios, compõem a parte central dos aparelhos estatais de Brasília (BRANCO, 2006; TIBURRI, 2013). Atualmente, além do Campus central, chamado Darcy Ribeiro, que se localiza na Asa Norte, a UnB possui mais três Campi em regiões administrativas do DF (Planaltina, Gama e Ceilândia). Conta com 337 cursos (154 cursos de graduação, sendo que 31 são noturnos), 86 de mestrado e 66 de doutorado); 2.695 docentes; 2.623 funcionários técnico-administrativos; 36.372 alunos de graduação; e 7.926 alunos de pós-graduação (UNB, 2015).

A UnB foi criada em 1962 (art. $3^{\circ}$ da Lei n. 3998/1961) com a missão de "ser uma instituição inovadora, comprometida com a excelência acadêmica, científica e tecnológica, formando cidadãos conscientes do seu papel transformador na sociedade, respeitadores da ética e da diversidade de identidades e culturas, e com responsabilidade social" (UNB, 2015). Fruto da idealização e do trabalho de Anísio Teixeira e Darcy Ribeiro num momento de expansão do número de IES, mas desprovido de qualidade, a UnB busca inspirar mudanças no ensino superior brasileiro (BORTOLETTI, 2012), e "estar entre as melhores universidades do Brasil, inserida internacionalmente, com excelência em gestão de processos que fortaleça o ensino, pesquisa e extensão" (UNB, 2015).

Historicamente vinculada ao ideal progressista e de fortalecimento da identidade brasileira, a UnB deveria oferecer um ensino superior de qualidade, respeitando a individualidade estudantil e o espaço da reflexão, pautado na competência e na elaboração de conhecimentos sobre a vida, que favorecessem a construção de uma sociedade mais evoluída humanamente (BORTOLETTI, 2012). A despeito de inúmeros exemplos de ações progressistas, tais como ser pioneira na adoção da política de cotas para ingresso na instituição e a garantia do direito ao uso do nome social para a população transgênero (CARVALHO, 2006; MAIO; SANTOS 2005), atualmente a Universidade, em consonância com o país, possui diversos grupos de representação que, por muitas vezes, em suas vertentes radicais não comungam com modelos de gestão democráticos (ARRUDA, 2012).

Geograficamente o Campus Central da UnB - o Darcy Ribeiro - localizado na Asa Norte é delimitado pelo Lago Paranoá, o setor de clubes norte e a avenida L2 norte (Figura 7). Sua estrutura comporta sete Decanatos, 26 Institutos e Faculdades, 55 Departamentos, duas Assessorias, quatro Secretarias, seis Órgãos Complementares, 19 Centros, um Hospital Universitário, dois Hospitais Veterinários, uma Fazenda, e dez Órgãos Diversos (UnB, 2014). 


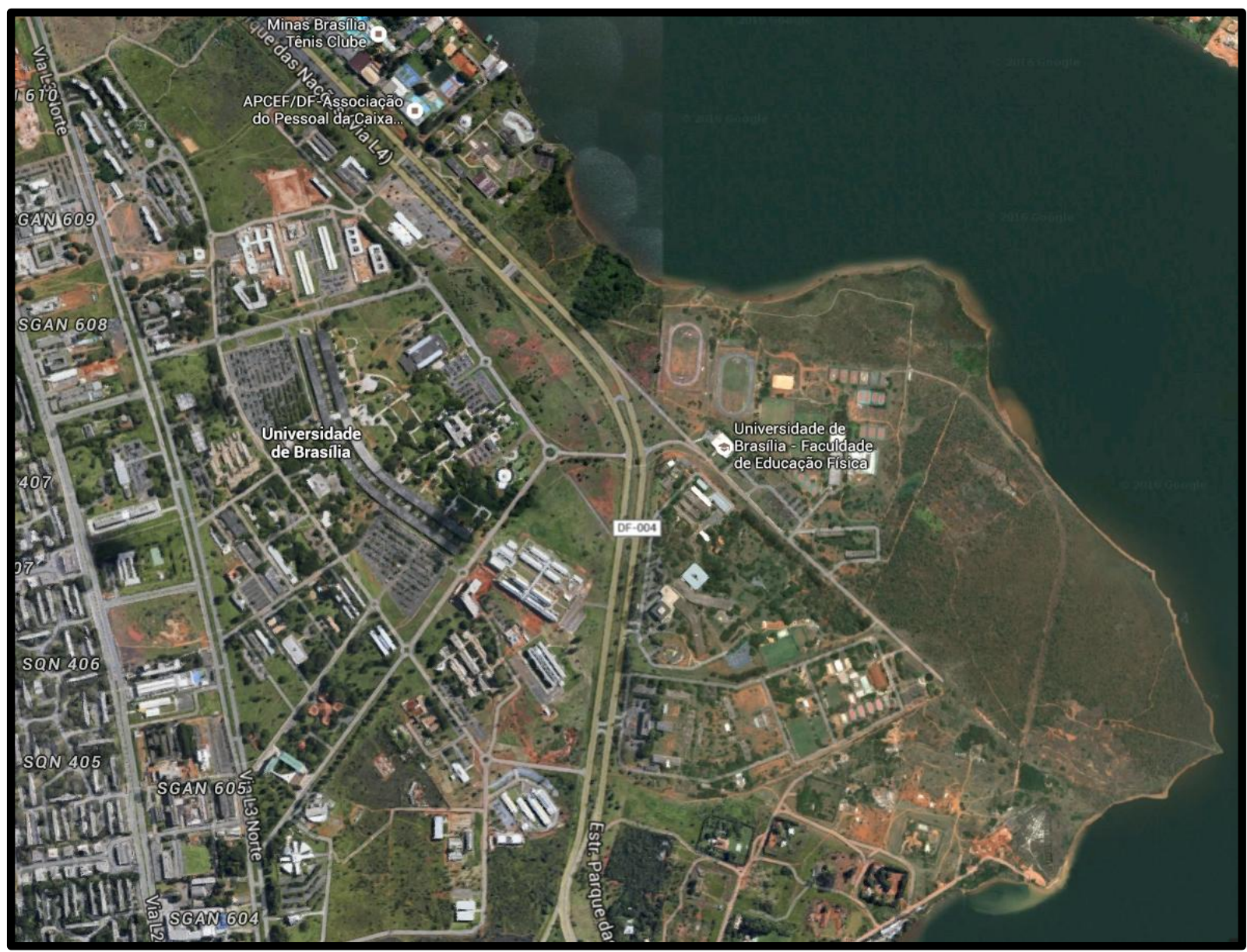

Figura 7. O Campus Darcy Ribeiro da Universidade de Brasília. Fonte: Google Maps (https://www.google.com.br/maps/).

Atualmente, avaliações externas apontam a UnB como uma das dez mais produtivas da América Latina, segundo ranking produzido pela companhia britânica Quacquarelli Symonds em 2014. Com dimensões de uma verdadeira cidade, a UnB é movimentada por uma comunidade acadêmica de mais de 50 mil pessoas. O número é ainda maior quando se inclui a presença de parceiros de outras instituições, visitantes e usuários da vasta gama de serviços oferecidos ao cidadão. Além dos cursos de formação em nível de graduação e pós-graduação, a UnB atende a população do DF e entorno por meio de diversas atividades e serviços de extensão, tais como o Centro de Atendimento e Estudos Psicológicos; o Programa Doce Desafio; o Programa educativo na Vila Planalto, dentre muitos outros (UnB, 2015).

Em termos de serviços relacionados à Promoção da Saúde de seus servidores, o Decanato de Gestão de Pessoas da UnB é responsável por desenvolver e promover a atenção à saúde, através da gestão e execução de atividades relativas à administração, ao provimento, ao 
acompanhamento, à movimentação, à capacitação, ao desenvolvimento, e à educação em saúde, segurança e qualidade de vida das pessoas que trabalham na UnB (UnB, 2015). 


\section{OBJETIVOS}

\subsection{OBJETIVO GERAL}

Compreender, a partir da percepção dos professores da FEF-UnB, o fenômeno da saúde relacionando-a ao contexto de trabalho, ao apoio institucional promotor do autocuidado, e ao cuidar de si, com especial atenção às práticas corporais.

\subsection{OBJETIVOS ESPECIFICOS}

Conhecer a percepção dos docentes sobre:

- sua situação de saúde;

- o contexto do trabalho universitário e suas relações com fatores de prazer e sofrimento;

- o apoio institucional ao autocuidado;o cuidar de si, em especial às atitudes e práticas corporais;

- as percepções vigentes sobre Promoção da Saúde. 


\section{METODOLOGIA}

Para alcançar os objetivos propostos, o desenvolvimento do presente estudo passou por três etapas complementares (Quadro 1). Cabe destacar que os processos exploratórios e de reflexão perpassam todo o período do estudo e que a opção de representação em um esquema por etapas se destina à organização descritiva na redação da dissertação. As etapas exploratórias e de trabalho de campo serão descritas em detalhes a seguir. A etapa reflexiva compõe o capítulo de discussão do presente trabalho.

Quadro 1. Delineamento metodológico do estudo desenvolvido com professores da Faculdade de Educação Física da Universidade de Brasília; 2015.

\begin{tabular}{|c|c|c|c|}
\hline Etapa & $\begin{array}{l}\text { Atividades } \\
\text { realizadas }\end{array}$ & Estratégias de investigação & Objetivo Específico \\
\hline \multirow{2}{*}{ Exploratória } & $\begin{array}{l}\text { Aprofundamento no } \\
\text { tema. }\end{array}$ & $\begin{array}{l}\text { Revisão da literatura com } \\
\text { utilização das técnicas de } \\
\text { resenha e fichamento. }\end{array}$ & $\begin{array}{l}\text { Identificar referenciais teóricos } \\
\text { e instrumentos que se adequem } \\
\text { à pesquisa. }\end{array}$ \\
\hline & $\begin{array}{l}\text { Imersão no contexto e } \\
\text { Planejamento da } \\
\text { pesquisa. }\end{array}$ & $\begin{array}{l}\text { Registros em diário de } \\
\text { campo. }\end{array}$ & $\begin{array}{l}\text { Identificar variáveis e } \\
\text { informações relevantes no } \\
\text { contexto de trabalho. }\end{array}$ \\
\hline \multirow[b]{3}{*}{$\begin{array}{l}\text { Trabalho de } \\
\text { Campo }\end{array}$} & \multirow[b]{2}{*}{$\begin{array}{l}\text { Aplicação de } \\
\text { Questionários }\end{array}$} & $\begin{array}{l}\text { Escala de Avaliação do } \\
\text { Contexto de Trabalho }\end{array}$ & $\begin{array}{l}\text { Mapear o contexto de trabalho } \\
\text { quanto à organização, condições } \\
\text { e relações. }\end{array}$ \\
\hline & & $\begin{array}{l}\text { Cartão de Pontuação do } \\
\text { Apoio à Saúde no Local de } \\
\text { Trabalho }\end{array}$ & $\begin{array}{l}\text { Identificar a percepção sobre o } \\
\text { apoio institucional ao } \\
\text { autocuidado à promoção da } \\
\text { saúde; atividade física e } \\
\text { gerenciamento de estresse. }\end{array}$ \\
\hline & $\begin{array}{l}\text { Realização de } \\
\text { Entrevista }\end{array}$ & $\begin{array}{l}\text { Análise de conteúdo e } \\
\text { categorização }\end{array}$ & $\begin{array}{l}\text { Conhecer a percepção dos } \\
\text { docentes sobre: situação de } \\
\text { saúde; contexto do trabalho e } \\
\text { fatores de prazer e sofrimento; } \\
\text { autocuidado apoiado; atitudes } \\
\text { de cuidar de si, com especial } \\
\text { atenção às práticas corporais; e } \\
\text { conceito de Promoção da } \\
\text { Saúde. }\end{array}$ \\
\hline Reflexiva & Discussão do tema & $\begin{array}{l}\text { Uso dos referenciais teóricos } \\
\text { de Promoção da Saúde } \\
\text { Paradigma da complexidade }\end{array}$ & $\begin{array}{l}\text { Refletir, a partir do discurso dos } \\
\text { professores da Educação Física. }\end{array}$ \\
\hline
\end{tabular}




\subsection{Aprofundamento no tema}

Como parte inicial da etapa exploratória foi realizada uma revisão de literatura que, além de permitir a identificação de referenciais teóricos pertinentes e proporcionar maior familiarização com o problema de pesquisa, subsidiou toda a discussão dos resultados encontrados no presente estudo.

A busca dos estudos foi realizada nas bases de dados PubMed, Medline, Lilacs (Biblioteca Virtual em Saúde), Scielo, Google Scholar, Periódico Capes e na Biblioteca Digital Brasileira de Teses e Dissertações do Instituto Brasileiro de Informação em Ciência e Tecnologia disponíveis na Internet. Os descritores utilizados, em diferentes combinações, foram: "saúde, bem estar, promoção de saúde, percepção de saúde, ambiente de trabalho, professores, universidade, autocuidado, cuidado de si, educação física, práticas corporais, e atividades físicas," em português e "health, wellness, health promotion, health perception, work environment, professor, university, self-care, physical education, body practices, and physical activity” em inglês. As referências bibliográficas dos estudos encontrados também foram pesquisadas a fim de localizar mais trabalhos sobre o tema. Em adição, documentos disponíveis no site institucional (www.unb.br) e material de literatura cinza (gray literature) relevantes à temática também foram consultados.

Foram selecionados os estudos da última década (2006 a 2016) que atenderam aos critérios de inclusão: ser trabalho científico (artigo, dissertação ou tese) disponível na íntegra online; ter amostra com professores universitários brasileiros de cursos que formam profissionais da grande área da saúde de acordo com a Resolução nº ${ }^{\circ}$ 287/1998 do Conselho Nacional de Saúde ${ }^{1}$ (CNS, 1998); pesquisar sobre a situação de saúde no sentido amplo, contemplando mais de um indicador; e abordar os determinantes e condicionantes da saúde relacionados ao trabalho. Não foram incluídos estudos exclusivamente descritivos sobre prevalência de doenças ou um único fator de risco como, por exemplo, somente distúrbios da voz, síndrome da exaustão (Burnout), estilo de vida, ou dores em docentes. Em adição, foram excluídos estudos que contemplavam cursos superiores de outras áreas e que não apresentaram os resultados estratificados para a área da saúde.

Consultas iniciais às bases de dados retornaram 81 publicações sobre o tema. De forma a traçar um panorama sobre os aspectos da saúde relacionados ao trabalho de docentes universitários da área da saúde, os estudos foram tabulados após uma leitura flutuante dos

\footnotetext{
${ }^{1}$ Resolução CNS no 287, de 08 de outubro de 1998 - Relacionar as seguintes categorias profissionais de saúde de
} 
resumos. Foram excluídos trabalhos que apareceram duplicados em mais de uma base de dados (eg. dissertação e artigo) e aqueles que fugiram à temática e/ou à adequação aos critérios de inclusão: 24 estudos com professores de cursos superiores de outras áreas que não apresentaram resultados estratificados para a área da saúde; 20 estudos que abordaram um único critério de saúde e/ou não avaliaram fatores condicionantes ou determinantes da saúde associados ao trabalho, e 17 relacionados exclusivamente à formação e desenvolvimento docente em saúde.

Como síntese desse processo apresentamos as características dos 20 estudos selecionados (três teses, cinco dissertações e doze artigos científicos) tabuladas no Quadro 2. As informações sobre: autores e ano da publicação, região de realização, e seus principais métodos, objetivos, resultados e conclusões foram agrupados por tipo de pesquisa (quantitativa, qualitativa ou mista) e ordenados crescentemente por ano de publicação e, quando do mesmo ano, em ordem alfabética considerando o primeiro autor. 
Quadro 2: Características das publicações sobre saúde e fatores associados em professores universitários da área da saúde.

\begin{tabular}{|c|c|c|c|c|}
\hline Autor, ano & Amostra & Desenho e Instrumentos & Objetivos & Principais resultados e conclusões \\
\hline Lemos, 2005 & $\begin{array}{l}\text { 86 professores } \\
\text { - Cursos } 1,2,3,4, \\
5 \text { e } 12 . \\
\text { - 60,5\% D.E. } \\
\text { - 64\% mulheres. } \\
\text { - Federal em } \\
\text { Santa Maria, RS. }\end{array}$ & $\begin{array}{l}\text { Quantitaivo, Exploratório, } \\
\text { com Questionários de: } \\
\text {-Avaliação da Carga Psíquica } \\
\text { do trabalho (Q-CP), } \\
\text {-Bem-Estar Psicológico. }\end{array}$ & $\begin{array}{l}\text { - Caracterizar as cargas } \\
\text { psíquicas no trabalho e } \\
\text { sua influência nos } \\
\text { processos de saúde. }\end{array}$ & $\begin{array}{l}\text { - As dimensões físicas e psicológicas da carga de trabalho } \\
\text { apresentam relação com a percepção das condições de trabalho e dos } \\
\text { riscos de adoecimento. } \\
\text { - As condições de trabalho e o estado de bem-estar psicológico do } \\
\text { professor influenciam significativamente os processos de saúde e } \\
\text { adoecimento. } \\
\text { - A dor e desconforto estão intimamente relacionados à precariedade } \\
\text { das condições de trabalho. O tempo de docência e o número de } \\
\text { disciplinas lecionadas no semestre não parecem afetar esses aspectos. } \\
\text { - A precarização das relações de trabalho apresenta repercussões na } \\
\text { saúde dos professores e na qualidade do ensino superior público. }\end{array}$ \\
\hline Ulrich, 2005 & $\begin{array}{l}\text { 11 professores } \\
\text { - Curso } 8 . \\
\text { - 45,5\% D.E. } \\
\text { - 36,4\% mulheres. } \\
\text { - Municipal no } \\
\text { interior RS. }\end{array}$ & $\begin{array}{l}\text { Qualitativo, Exploratório, } \\
\text { com Entrevistas sobre: } \\
\text {-percepção do trabalho, } \\
\text { relações interpessoais, } \\
\text { relações hierárquicas, e } \\
\text { trabalho e saúde. }\end{array}$ & $\begin{array}{l}\text { Verificar se professores } \\
\text { compreendem as } \\
\text { relações interpessoais } \\
\text { como determinantes de } \\
\text { desgaste físico e } \\
\text { psicológico (estresse). }\end{array}$ & $\begin{array}{l}\text { - Em geral professores indicaram mais aspectos desagradáveis do } \\
\text { que agradáveis no trabalho e em situação especificas de relação } \\
\text { pessoal. Essa percepção pode gerar um desgaste físico e psicológico } \\
\text { dos professores. } \\
\text { - A falta de colaboração entre os docentes e o não envolvimento dos } \\
\text { professores em atividades fora de sala de aula contribui para que o } \\
\text { ensino seja realizado de forma fragmentada. } \\
\text { - Situações agradáveis relatadas se referem ao relacionamento } \\
\text { interpessoal, notadamente a "colaboração" e, na categoria "ambiente } \\
\text { de trabalho", há o "crescimento da organização". }\end{array}$ \\
\hline $\begin{array}{l}\text { Garcia, } \\
\text { Oliveira e } \\
\text { Mauro, 2008 }\end{array}$ & $\begin{array}{l}25 \text { professores } \\
\text { - Cursos } 1,2,4,6, \\
7,8,12 \text { e } 13 . \\
\text { - 76\% mulheres. } \\
\text { - Tipo N.I. no ES. }\end{array}$ & $\begin{array}{l}\text { Qualitativo, Exploratório, } \\
\text { com Entrevistas sobre: } \\
\text {-fatores que afetam a } \\
\text { qualidade de vida } \\
\text {-repercussão do trabalho nas } \\
\text { demais relações sociais e } \\
\text { condições e organização do } \\
\text { trabalho. }\end{array}$ & $\begin{array}{l}\text { - Analisar as condições } \\
\text { de trabalho no âmbito } \\
\text { das transformações } \\
\text { econômicas, sociais e } \\
\text { culturais. }\end{array}$ & $\begin{array}{l}\text { - Condições de trabalho negativas foram a situação financeira e a } \\
\text { estrutura física da instituição, as pressões psicológicas e a falta de } \\
\text { espaços para a troca de ideias. } \\
\text { - A dedicação à atividade docente dificulta sua integração na vida } \\
\text { para além dos espaços da faculdade. } \\
\text { - O docente se encontra só, sem apoio social necessário, com pouco } \\
\text { apoio institucional e mergulhado em demandas e exigências, que } \\
\text { intensificam um sentido negativo do processo de trabalho. } \\
\text { - Aspectos positivos que melhoram a qualidade de vida foram a }\end{array}$ \\
\hline
\end{tabular}




\begin{tabular}{|c|c|c|c|c|}
\hline & & & & $\begin{array}{l}\text { satisfação relacionada à produção de conhecimento sistematizado e o } \\
\text { impacto social que suas atividades promovem. } \\
\text { - O próprio docente é capaz de desenvolver estratégias (internas e } \\
\text { externas) de melhoria na qualidade de vida resgatando a função } \\
\text { social de prazer e solidariedade nas relações de trabalho. }\end{array}$ \\
\hline $\begin{array}{l}\text { Lima e } \\
\text { Filho, } 2009\end{array}$ & $\begin{array}{l}\mathbf{1 8 9} \text { professores } \\
\text { - Cursos } 1,2,4,5 \text {, } \\
6 \text { e } 11 . \\
\text { - } 74,9 \% \text { D.E. } \\
38,5 \% \text { mulheres. } \\
\text {-Federal em } \\
\text { Campo Grande, } \\
\text { MS. }\end{array}$ & $\begin{array}{l}\text { Quanti-Qualitativo, } \\
\text { Exploratório com } \\
\text { Questionários de: } \\
\text {-condições físicas e } \\
\text { atividades do trabalho, } \\
\text { e Entrevistas sobre: } \\
\text {-problemas e doenças } \\
\text { associados ao trabalho, } \\
\text {-relação com os pares e } \\
\text { expectativas com a carreira. }\end{array}$ & $\begin{array}{l}\text { - Verificar relações } \\
\text { entre o processo e as } \\
\text { condições de trabalho e } \\
\text { o adoecimento físico e } \\
\text { mental. }\end{array}$ & $\begin{array}{l}\text { - A precarização do trabalho docente decorre de insuficiência de } \\
\text { pessoal, sobrecarga de trabalho, falta de materiais, equipamentos, } \\
\text { apoio administrativo e ambiente inadequado. } \\
\text { - O ambiente do trabalho (incluindo ruídos, ventilação umidade, } \\
\text { temperatura, arranjo físico e segurança) é considerado fator de risco } \\
\text { para danos físicos ou mentais. } \\
\text { • Os processos de trabalho interferem na saúde de professores, sejam } \\
\text { relacionados à natureza das funções que exercem ou vinculados ao } \\
\text { contexto institucional e social onde estes são exercidos. }\end{array}$ \\
\hline $\begin{array}{l}\text { Marqueze e } \\
\text { Moreno, } \\
2009\end{array}$ & $\begin{array}{l}\text { 154 professores } \\
\text { - Cursos da saúde } \\
\text { N.I. } \\
\text { - 49,4\% mulheres. } \\
\text { - Tipo e Local } \\
\text { N.I. }\end{array}$ & $\begin{array}{l}\text { Quantitativo com } \\
\text { Questionários de: } \\
\text {-satisfação no trabalho do } \\
\text { Occupational Stress } \\
\text { Indicator (OSI), } \\
\text {-Índice de Capacidade para o } \\
\text { Trabalho. }\end{array}$ & $\begin{array}{l}\text { - Verificar a relação } \\
\text { entre satisfação no } \\
\text { trabalho e capacidade } \\
\text { para o trabalho. }\end{array}$ & $\begin{array}{l}\text { - Aspectos de insatisfação com o trabalho (volume de trabalho, grau } \\
\text { de instabilidade no emprego e grau que a instituição absorve suas } \\
\text { potencialidades) estão relacionados à gestão da Universidade. } \\
\text { - Aspectos de satisfação com o trabalho estão relacionados ao } \\
\text { conteúdo e ambiente do trabalho, relacionamento interpessoal e } \\
\text { motivação. } \\
\text { - A diminuição da capacidade para o trabalho pode ter relação com a } \\
\text { atuação paralela dos docentes em serviços de saúde, o que exige } \\
\text { grande envolvimento cognitivo. }\end{array}$ \\
\hline $\begin{array}{l}\text { Silvério et } \\
\text { al., } 2009\end{array}$ & $\begin{array}{l}27 \text { professores } \\
\text { - Cursos 1, 2, 3, 4, } \\
5 \text { e } 6 . \\
\text { - Sexo N.I. } \\
\text { - Federal em } \\
\text { Santa Catarina, } \\
\text { SC. }\end{array}$ & $\begin{array}{l}\text { Qualitativo, Exploratório, } \\
\text { com Entrevistas sobre: } \\
\text {-fatores ambientais que } \\
\text { influenciam os processos de } \\
\text { ensino-aprendizagem e a } \\
\text { qualidade de vida e saúde. }\end{array}$ & $\begin{array}{l}\text { - Conhecer a } \\
\text { repercussão do processo } \\
\text { de ensino- } \\
\text { aprendizagem na } \\
\text { qualidade de vida e } \\
\text { saúde de docentes. }\end{array}$ & $\begin{array}{l}\text { - As interações sociais nos diversos contextos do processo de ensino- } \\
\text { aprendizagem e nas demais relações do cotidiano universitário } \\
\text { interferem significativamente na qualidade de vida e saúde dos } \\
\text { docentes. } \\
\text { - O excesso de horas de trabalho, a falta de tempo e os conflitos e } \\
\text { dilemas éticos que envolvem o professor foram fatores limitantes da } \\
\text { qualidade de vida dos docentes. } \\
\text { - Interações entre professor, aluno e população (incluindo } \\
\text { demonstrações de respeito e reconhecimento do trabalho, troca de } \\
\text { conhecimentos e afetividades) promovem realização pessoal e }\end{array}$ \\
\hline
\end{tabular}




\begin{tabular}{|c|c|c|c|c|}
\hline & & & & profissional. \\
\hline $\begin{array}{l}\text { Fontana e } \\
\text { Pinheiro, } \\
2010\end{array}$ & $\begin{array}{l}34 \text { professores } \\
\text { - Cursos 2, } 5 \text { e } 8 . \\
\text { - 41,1\% D.E. } \\
\text { - 62\% mulheres. } \\
\text { - Regional no } \\
\text { Noroeste do RS. }\end{array}$ & $\begin{array}{l}\text { Quantitativo, } \\
\text { Epidemiológico, com } \\
\text { Questionários de: } \\
\text {-condições de trabalho e } \\
\text { saúde, incluindo queixas de } \\
\text { morbidade e exposição a } \\
\text { riscos ocupacionais. }\end{array}$ & $\begin{array}{l}\text { - Investigar as } \\
\text { condições de saúde } \\
\text { auto-referidas e a } \\
\text { interface com a } \\
\text { ocupação profissional. }\end{array}$ & $\begin{array}{l}\text { - A maior queixa dos professores foram às dores, associadas aos } \\
\text { longos períodos em pé e às tensões. } \\
\text { - Interfaces negativas decorrem da situação dos ambientes de prática } \\
\text { externos, considerados deficitários de conforto e praticidade (e.g.: } \\
\text { faltam salas, mobiliários e informatização adequados). } \\
\text { - Interfaces positivas se referem à infraestrutura apropriada, } \\
\text { laboratórios para a prática do ensino, organização da universidade, } \\
\text { boas relações interpessoais e salário acima da média. } \\
\text { - A gestão que priorize promover a saúde deve valorizar o docente, } \\
\text { diminuir a carga de trabalho, e oferecer melhores condições, recursos } \\
\text { e fomentos para a concretização digna do ensino, pesquisa e } \\
\text { extensão. }\end{array}$ \\
\hline $\begin{array}{l}\text { Coutinho et } \\
\text { al., } 2011\end{array}$ & $\begin{array}{l}8 \text { professores } \\
\text { - Cursos } 6 \text { e } 11 . \\
\text { - } 37,5 \% \text { D.E. } \\
\text { - } 75 \% \text { mulheres. } \\
\text { - Pública e } \\
\text { Privada em local } \\
\text { NI. }\end{array}$ & $\begin{array}{l}\text { Qualitativo, Exploratório, } \\
\text { com Entrevistas sobre: } \\
\text {-trajetória profissional; } \\
\text { condições, carga, ambiente e } \\
\text { relações e expectativas no } \\
\text { trabalho; pressões e } \\
\text { estratégias de resistência. }\end{array}$ & $\begin{array}{l}\text { - Compreender os } \\
\text { sentidos de prazer e } \\
\text { sofrimento no } \\
\text { trabalho. }\end{array}$ & $\begin{array}{l}\text { - Vivencias de sofrimento foram associadas ao desgaste provocado } \\
\text { pela grande carga de trabalho, o medo e a insegurança de contratos } \\
\text { precários, e as relações hierarquizadas e competitivas no contexto } \\
\text { organizacional que minam as relações solidárias. } \\
\text { - Vivencias positivas envolvem relações de troca e amizade com } \\
\text { colegas e alunos e o reconhecimento do trabalho. A atividade } \\
\text { docente como pratica criativa propicia reconhecimento e identidade } \\
\text { aos entrevistados. }\end{array}$ \\
\hline $\begin{array}{l}\text { Ferreira, } \\
2011\end{array}$ & $\begin{array}{l}\text { 108 professores } \\
\text { - Cursos } 1,2,4,5 \\
\text { e } 7 . \\
\text { - 65,7\% D.E. } \\
\text { - 68,5\% mulheres. } \\
\text { - Pública em } \\
\text { Goiânia, GO. }\end{array}$ & $\begin{array}{l}\text { Quantitativo, Exploratório } \\
\text { com Questionários de: } \\
\text {-Qualidade de Vida em } \\
\text { relação à Saúde (Medical } \\
\text { Outcome Study); } \\
\text {-Satisfação no Trabalho } \\
\text { (S20/23). }\end{array}$ & $\begin{array}{l}\text { - Analisar a satisfação } \\
\text { no trabalho e seu } \\
\text { reflexo na qualidade de } \\
\text { vida. }\end{array}$ & $\begin{array}{l}\text { - A insatisfação dos docentes foi maior nos itens de relação } \\
\text { hierárquica e ambiente físico. } \\
\text { - A satisfação com o trabalho refere-se à realização, onde faz coisas } \\
\text { que gosta e se destaca. Esse aspecto afeta positivamente a qualidade } \\
\text { de vida. } \\
\text { - Gestores e docentes devem conjuntamente desenvolver uma gestão } \\
\text { universitária inovadora, que minimize as limitações físicas do } \\
\text { ambiente laboral e favoreça o diálogo e a participação nas decisões } \\
\text { coletivas. }\end{array}$ \\
\hline Priess, 2011 & $\begin{array}{l}\text { 88 professores } \\
\text { - Cursos } 2,5,6,7 \text {, } \\
8,10 \text { e } 11 .\end{array}$ & $\begin{array}{l}\text { Quantitativo, Exploratório } \\
\text { com Questionários de: } \\
\text {-Avaliação da Qualidade de }\end{array}$ & $\begin{array}{l}\text { - Analisar aspectos do } \\
\text { estilo e da qualidade de } \\
\text { vida e comparar com a }\end{array}$ & $\begin{array}{l}\text { - No geral os professores relatam um nível de satisfação excelente } \\
\text { com os ambientes laborais. } \\
\text { - Os domínios ambiente ocupacional e saúde representaram os }\end{array}$ \\
\hline
\end{tabular}




\begin{tabular}{|c|c|c|c|c|}
\hline & $\begin{array}{l}\text { - 25\% D.E. } \\
\text { - 59\% mulheres. } \\
\text { - Privada em Foz } \\
\text { do Iguaçu, PR. }\end{array}$ & $\begin{array}{l}\text { Vida e Saúde (QVS-80) nos } \\
\text { domínios: saúde, atividade } \\
\text { física, ambiente ocupacional } \\
\text { e } \\
\text {-Percepção da qualidade de } \\
\text { vida. }\end{array}$ & $\begin{array}{l}\text { pratica regular de } \\
\text { atividades físicas. }\end{array}$ & $\begin{array}{l}\text { menores impactos na qualidade de vida. } \\
\text { - O domínio da atividade física representou o maior impacto na } \\
\text { qualidade de vida. Há elevada prevalência de docentes sedentários, } \\
\text { inclusive na educação física, estando mais propensos a doenças } \\
\text { crônicas. }\end{array}$ \\
\hline $\begin{array}{l}\text { Servilha e } \\
\text { Arbach, } \\
2011\end{array}$ & $\begin{array}{l}\text { 85 professores } \\
\text { - Cursos da saúde } \\
\text { N.I. } \\
\text { - 33,3\% D.E. } \\
\text { - 71,4\% mulheres. } \\
\text { - Tipo e local N.I. }\end{array}$ & $\begin{array}{l}\text { Quantitativo, } \\
\text { Epidemiológico, com } \\
\text { Questionários de: } \\
\text { - com informações pessoais, } \\
\text { profissionais e de saúde. } \\
\text { - produção vocal do } \\
\text { professor (CPV-P), }\end{array}$ & $\begin{array}{l}\text { - Investigar a relação } \\
\text { entre condições } \\
\text { organizacionais do } \\
\text { trabalho e queixas de } \\
\text { saúde. }\end{array}$ & $\begin{array}{l}\text { - Condições organizacionais negativas: ritmo de trabalho estressante, } \\
\text { levar trabalho para casa, interferência de fatores do ambiente de } \\
\text { trabalho na vida pessoal, esforço físico ao carregar peso com } \\
\text { frequência, supervisão constante e trabalho repetitivo. } \\
\text { - Condições organizacionais positivas: condições de higiene, } \\
\text { mobiliário, tempo para desenvolver as atividades, espaço para } \\
\text { movimentação, tamanho das salas adequado, ambiente de trabalho } \\
\text { calmo, e facilidade para se ausentar da sala de aula. } \\
\text { - Queixas de saúde mais frequentes foram problemas respiratórios, } \\
\text { osteoarticulares, gastrintestinais e vocais. } \\
\text { - IES devem prezar pelo aperfeiçoamento progressivo e sistemático } \\
\text { das condições de trabalho, favorecendo sua missão de produção de } \\
\text { conhecimentos, valores e desenvolvimento humano. }\end{array}$ \\
\hline $\begin{array}{l}\text { Oliveira et } \\
\text { al., } 2012\end{array}$ & $\begin{array}{l}19 \text { professores } \\
\text { - Cursos N.I. } \\
\text { - 100\% mulheres. } \\
\text { - Pública e } \\
\text { Privada em } \\
\text { Vitória, ES. }\end{array}$ & $\begin{array}{l}\text { Qualitativo, Exploratório } \\
\text { com Entrevistas sobre: } \\
\text { - dedicação à família, lazer e } \\
\text { trabalho. }\end{array}$ & $\begin{array}{l}\text { - Avaliar as condições } \\
\text { de trabalho sobre a } \\
\text { saúde e a qualidade de } \\
\text { vida percebida. }\end{array}$ & $\begin{array}{l}\text { - Excesso de trabalho e alterações significativas em sua organização } \\
\text { provocam falta de tempo para lazer, comprometimento da interação } \\
\text { social e familiar, aumento de distúrbios do sono, favorecimento de } \\
\text { doenças psíquicas e redução da saúde e da qualidade de vida. } \\
\text { - Tarefas extraclasse, extensa jornada de trabalho, curto prazo para } \\
\text { cumprir tarefas, múltiplos empregos e elevada carga horária em sala, } \\
\text { lém de grau elevado de relação com o público, tem resultado em } \\
\text { Esgotamento Profissional. }\end{array}$ \\
\hline Rohde, 2012 & $\begin{array}{l}\text { 10 professores } \\
\text { - Curso } 6 . \\
\text { - } 40 \% \text { mulheres. } \\
\text { - Federal na } \\
\text { Região Sul. }\end{array}$ & $\begin{array}{l}\text { Qualitativo, Exploratório, } \\
\text { com Entrevistas sobre } \\
\text { aspectos: } \\
\text { - físico, psicológico, relações } \\
\text { sociais e ambiente. }\end{array}$ & $\begin{array}{l}\text { - Compreender a } \\
\text { percepção sobre } \\
\text { qualidade de vida no } \\
\text { trabalho. }\end{array}$ & $\begin{array}{l}\text { - Angústia em relação ao local não propício ao desenvolvimento da } \\
\text { docência, afetando a qualidade de vida. } \\
\text { - Aspectos positivos indicam dedicação, comprometimento, respeito } \\
\text { e admiração pela Instituição. } \\
\text { - Há a necessidade de conscientização dos professores e da } \\
\text { Instituição sobre o cuidado com a saúde e sua relação com o }\end{array}$ \\
\hline
\end{tabular}




\begin{tabular}{|c|c|c|c|c|}
\hline & & & & ambiente de trabalho. \\
\hline Santos, 2013 & $\begin{array}{l}\mathbf{1 7 5} \text { professores } \\
\text { - Cursos todos } \\
\text { menos o } 9 . \\
\text { - 92\% D.E. } \\
\text { - 60,6\% mulheres. } \\
\text { - Federal em } \\
\text { Recife, PE. }\end{array}$ & $\begin{array}{l}\text { Quantitativo, Exploratório, } \\
\text { com Questionários de: } \\
\text {-Atividade docente, ambiente } \\
\text { de trabalho e saúde, } \\
\text {-Características psicossociais } \\
\text { do trabalho (JSS), } \\
\text {-Emoções (SRQ-20), } \\
\text {-Apoio social geral (MOS- } \\
\text { SSS), } \\
\text {-Escala de Bem Estar no } \\
\text { Trabalho (EBET). }\end{array}$ & $\begin{array}{l}\text { - Conhecer a associação } \\
\text { entre Bem Estar no } \\
\text { Trabalho e as } \\
\text { condições físicas e } \\
\text { organizacionais do } \\
\text { trabalho. }\end{array}$ & $\begin{array}{l}\text { - As condições físicas e organizacionais do ambiente de trabalho não } \\
\text { constituem um fator significativo para determinar o bem estar dos } \\
\text { docentes. } \\
\text {-É possível que a instituição investigada ofereça condições mínimas } \\
\text { de trabalho aos professores, o que diminui a percepção do impacto } \\
\text { negativo desse aspecto sobre o bem estar. }\end{array}$ \\
\hline $\begin{array}{l}\text { Dallacosta, } \\
2014\end{array}$ & $\begin{array}{l}\text { 139 professores } \\
\text { - Cursos } 1,2,3,4, \\
6,8 \text { e } 11 . \\
-74,9 \% \text { D.E. } \\
\text { - } 51,1 \% \\
\text { mulheres. } \\
\text { - } 2 \text { IES privadas } \\
\text { em Santa } \\
\text { Catarina, SC. }\end{array}$ & $\begin{array}{l}\text { Quanti-Qualitativo, } \\
\text { Exploratório com } \\
\text { Questionários de: } \\
\text {-Occupational Stress } \\
\text { Indicator }(\text { OSI), } \\
\text {-Inventário de Burnout de } \\
\text { Maslach (MBI). } \\
\text { e Entrevistas sobre: } \\
\text {-dados sociodemográficos e } \\
\text { situação profissional. }\end{array}$ & $\begin{array}{l}\text { - Avaliar a satisfação } \\
\text { no trabalho e o } \\
\text { esgotamento } \\
\text { profissional. }\end{array}$ & $\begin{array}{l}\text { - Os professores apresentaram altos índices de exaustão emocional, } \\
\text { despersonalização e pouca realização pessoal no trabalho, critérios } \\
\text { para diagnóstico do esgotamento profissional. Há associação } \\
\text { negativa entre esgotamento e satisfação no trabalho, idade e tempo } \\
\text { de docência. } \\
\text { - A maior motivação para a docência foi à atualização e o } \\
\text { aprendizado constantes decorrentes da profissão. } \\
\text { - As IES devem promover um trabalho mais prazeroso, valorizado e } \\
\text { humanizado e menos desgastante. }\end{array}$ \\
\hline $\begin{array}{l}\text { Ferreira et } \\
\text { al., } 2015\end{array}$ & $\begin{array}{l}\mathbf{1 7 5} \text { professores } \\
\text { - Cursos } 1,2,3,4, \\
\text { 5, 7, 8 e } 12 . \\
\text { - 31,8 D.E. } \\
\text { - 53,1\% mulheres. } \\
\text { - Privada de } \\
\text { Minas Gerais, } \\
\text { MG. }\end{array}$ & $\begin{array}{l}\text { Quantitativo, Exploratório } \\
\text { com Questionários com: } \\
\text { - avaliação de qualidade de } \\
\text { vida (WHOQOL-bref); } \\
\text { - dados demográficos, } \\
\text { comportamentos e história } \\
\text { ocupacional; } \\
\text { - Sobre Saúde Geral (QSG- } \\
\text { 12); } \\
\text { - Escala de esforço, } \\
\text { recompensa, e }\end{array}$ & $\begin{array}{l}\text { - Avaliar a associação } \\
\text { entre estressores no } \\
\text { trabalho e transtornos } \\
\text { mentais. }\end{array}$ & $\begin{array}{l}\text { - A prevalência de transtornos mentais foi maior entre professores } \\
\text { com maior tempo de trabalho e menor naqueles com maior } \\
\text { qualidade de vida no domínio físico. }\end{array}$ \\
\hline
\end{tabular}




\begin{tabular}{|c|c|c|c|c|}
\hline & & $\begin{array}{l}\text { comprometimento no } \\
\text { trabalho; } \\
\text { - Questionário Internacional } \\
\text { de Atividades Físicas (IPAQ) }\end{array}$ & & \\
\hline $\begin{array}{l}\text { Gonçalves e } \\
\text { Pires, } 2015\end{array}$ & $\begin{array}{l}25 \text { professores } \\
\text { - curso } 1,2 \text { e } 4 . \\
\text { - } 76 \% \text { mulheres. } \\
\text { - Federal da } \\
\text { Região Norte, } \\
\text { PA. }\end{array}$ & $\begin{array}{l}\text { Qualitativo, Exploratório- } \\
\text { descritivo, com Entrevistas } \\
\text { sobre: } \\
\text { - situações geradoras de } \\
\text { prazer no trabalho } \\
\text { - situações geradoras de } \\
\text { sofrimento no trabalho }\end{array}$ & $\begin{array}{l}\text { - Analisar as situações } \\
\text { geradoras de prazer e } \\
\text { sofrimento no trabalho } \\
\text { de docentes da saúde. }\end{array}$ & $\begin{array}{l}\text { - O sofrimento provém da insuficiência da remuneração, da } \\
\text { precariedade da infraestrutura e das dificuldades nas relações } \\
\text { interpessoais. } \\
\text { - Os resultados mostraram que o prazer advém do gostar da } \\
\text { docência, do reconhecimento e dos bons resultados do trabalho } \\
\text { realizado. } \\
\text { - Conclui que as situações geradoras de prazer e de sofrimento se } \\
\text { expressam dialeticamente no processo de trabalho dos docentes } \\
\text { universitários da saúde e que gostar do que faz promove satisfação, } \\
\text { ainda que as condições de trabalho causem sofrimento. }\end{array}$ \\
\hline $\begin{array}{l}\text { Lago, } \\
\text { Cunha e } \\
\text { Borges, } 2015\end{array}$ & $\begin{array}{l}\text { 6 professores } \\
\text { - Cursos 1, 2, 7, } 8 \\
\text { e } 9 . \\
\text { - } 66,5 \% \\
\text { mulheres. } \\
\text { - Federal na } \\
\text { Região Norte. }\end{array}$ & $\begin{array}{l}\text { Qualitativo, Exploratório- } \\
\text { descritivo, com Entrevistas: } \\
\text {-expectativas, dificuldades e } \\
\text { facilidades no trabalho, } \\
\text {-mudanças na qualidade de } \\
\text { vida e saúde, } \\
\text {-inter-relação com discentes } \\
\text { e profissionais, } \\
\text {-estratégias de ensino- } \\
\text { aprendizagem utilizadas. }\end{array}$ & $\begin{array}{l}\text { • Conhecer a percepção } \\
\text { da experiência do } \\
\text { trabalho docente em } \\
\text { relação à saúde. }\end{array}$ & $\begin{array}{l}\text { - Aspectos negativos incluem dificuldades no relacionamento com } \\
\text { alunos, decorrentes do momento de vida conflituoso (autonomia } \\
\text { conquistada vs. as novas exigências com o ingresso na faculdade). } \\
\text { - Aspectos positivos incluem autonomia criativa para exercer a } \\
\text { docência, oportunidade de formação continuada, estabilidade } \\
\text { empregatícia, e possibilidade de relações com alunos e professores. } \\
\text { - A maior parte dos docentes sente sua saúde vulnerável e } \\
\text { desgastada, principalmente em aspectos psicoemocionais, o que } \\
\text { influencia as relações dentro e fora do trabalho e a qualidade de vida. }\end{array}$ \\
\hline $\begin{array}{l}\text { Treviso, } \\
2015\end{array}$ & $\begin{array}{l}85 \text { professores } \\
\text { - cursos } 2,3,5,6, \\
7,8,10,12,13 \text { e } \\
\text { SS. } \\
\text { - } 27 \% \text { D.E. } \\
\text { - } 71 \% \text { mulheres. } \\
\text { - Privada no Rio } \\
\text { Grande do Sul, } \\
\text { RS. }\end{array}$ & $\begin{array}{l}\text { Quanti-Qualitativo, } \\
\text { Exploratório com } \\
\text { Questionários de: } \\
\text { - três categorias: Formação, } \\
\text { Atuação, Satisfação. } \\
\text { e Entrevistas sobre: } \\
\text { - características demográficas } \\
\text { da população; } \\
\text { - formação, atuação e } \\
\text { satisfação no trabalho. }\end{array}$ & $\begin{array}{l}\text { • Conhecer a percepção } \\
\text { sobre a formação, a } \\
\text { atuação e a satisfação } \\
\text { na atividade docente. }\end{array}$ & $\begin{array}{l}\text { - Fatores que interferem facilitando ou dificultando a realização do } \\
\text { trabalho de professor, além de aspectos que impactam na sua } \\
\text { satisfação, relacionados ao processo de ensino e de aprendizagem, } \\
\text { relações interpessoais, instituição de ensino superior, condições de } \\
\text { trabalho, além de questões pessoais do indivíduo professor. } \\
\text { - As condições de trabalho no processo de ensino e aprendizagem, } \\
\text { foram apontadas como fatores na IES que dificultam a prática } \\
\text { docente. } \\
\text { - As relações interpessoais foram apontadas como fatores que } \\
\text { facilitam a prática docente na IES. }\end{array}$ \\
\hline
\end{tabular}




\begin{tabular}{|c|c|c|c|c|}
\hline & & & & $\begin{array}{l}\text { - O trabalho docente exige estudo, dedicação, domínio de saberes } \\
\text { específicos e pedagógicos, além de habilidades e competências para } \\
\text { exercer a função docente. }\end{array}$ \\
\hline $\begin{array}{l}\text { Silva et al., } \\
2016\end{array}$ & $\begin{array}{l}21 \text { professores } \\
\text { - Curso } 1 \text { e } 2 . \\
\text { - 52,4\% D.E. } \\
\text { - 38,1\% mulheres. } \\
\text { - Federal do Rio } \\
\text { Grande do Norte, } \\
\text { RN. }\end{array}$ & $\begin{array}{l}\text { Qualitativo, Exploratório- } \\
\text { descritivo, com Entrevistas } \\
\text { sobre: } \\
\text { - atividades em uma semana } \\
\text { normal de trabalho; } \\
\text { - aspectos desgastante em } \\
\text { sala de aulas ou estágio; } \\
\text { - relacionamento interpessoal } \\
\text { na docência; } \\
\text { - atividades externas ao } \\
\text { trabalho. }\end{array}$ & $\begin{array}{l}\text { - Conhecer a percepção } \\
\text { quanto aos estressores } \\
\text { no ambiente } \\
\text { ocupacional. }\end{array}$ & $\begin{array}{l}\text { - O "estresse no cotidiano docente" revela o quanto os professores } \\
\text { são afetados pelo estresse; com diferenças nas vivências dos docentes } \\
\text { de Enfermagem e Medicina. } \\
\text { - O "corpo dos docentes" revela reflexos físicos e psicológicos do } \\
\text { estresse, com repercussão em nível individual e organizacional. } \\
\text { - Aspectos relacionados à sala de aula e ao sistema de saúde e } \\
\text { repercutem na forma de desgaste físico e emocional dos docentes } \\
\text { embora alguns momentos em sala sejam percebidos como um ato de } \\
\text { realização profissional. } \\
\text {-É importante cuidar da saúde física e mental dos docentes. }\end{array}$ \\
\hline
\end{tabular}

IES, Instituição de Ensino Superior; N.I., não informado; D.E., dedicação exclusiva; DCS, Departamento de Ciências da Saúde; Cursos: 1Medicina; 2-Enfermagem; 3-Fisioterapia; 4-Odontologia; 5-Farmácia; 6-Psicologia; 7-Nutrição; 8-Educação Física; 9-Saúde Coletiva; 10Biomedicina; 11-Ciências Biológicas; 12-Fonoaudiologia; 13-Terapia Ocupacional; SS, Serviço social; Estados: RS, Rio Grande do Sul; GO, Goiás; PE, Pernambuco; ES, Espírito Santo; MS, Mato Grosso do Sul; PR Paraná. 


\subsection{Imersão no Contexto e Planejamento do estudo}

Ainda como parte exploratória a pesquisadora, aluna do curso de pós-graduação da FEF-UnB, que já frequentava os ambientes da FEF, passou a adotar um olhar crítico quanto à realidade do campo de pesquisa, registrando suas impressões e informações obtidas no diário de campo. Essa etapa de imersão possibilitou a caracterização do cenário de pesquisa; permitiu a realização de levantamentos e esclarecimentos a respeito dos sujeitos e das variáveis estudadas; favoreceu o estabelecimento de vinculo entre a pesquisadora e os professores sujeitos da pesquisa; e simplificou a organização das entrevistas. Foi durante esse processo que a pesquisadora buscou informações nas Secretarias dos Cursos (Bacharelado e Licenciatura).

\subsection{População e amostra da Pesquisa}

A população da pesquisa foram todos os professores da FEF-UnB em atividade no segundo semestre 2015. Com base nas informações obtidas, a FEF tinha 46 docentes efetivos em seu quadro de professores; todos em regime de dedicação exclusiva. No referido período, oito professores estavam ausentes da FEF: três em gozo de licença capacitação e cinco afastados para realização de doutoramento ou estágio pós-doutoral. Desta forma, 38 professores foram considerados elegíveis para participar da presente pesquisa, tendo uma amostra de 22 professores (57\%).

\subsection{Aspectos Éticos}

A pesquisadora participou também de reuniões com a Direção da FEF-UnB para obtenção do termo de concordância em ser instituição co-participante da pesquisa (APÊNDICE A). Com esse termo em mãos e o projeto de pesquisa delineado, foi dado entrada no Comitê de Ética em Pesquisas com Seres Humanos (CEP) da Faculdade de Ciências da Saúde da Universidade de Brasília, seguindo a Resolução 466 de 2012, que regulamenta a pesquisa envolvendo seres humanos. O projeto foi aprovado pelo parecer FS/UnB, CAAE: 444939115.1.0000.0030, no parecer $n^{\circ} .1 .168 .660$ de 03 de agosto de 2015 (ANEXO II).

A participação na pesquisa foi livre e esclarecida, formalizada mediante carta convite e assinatura do Termo de Consentimento Livre e Esclarecido - TCLE (APÊNDICE B), onde constavam informações sobre: tema, objetivos e justificativa da pesquisa; participação voluntária, sigilosa, não invasiva e privada; sem custo ou risco físico ou emocional para o 
participante e a instituição à qual ele está vinculado; possibilidade de desistência a qualquer momento; e que a pesquisa e os procedimentos metodológicos da mesma foram respaldados pelo CEP-UnB.

\subsection{Trabalho de campo}

\subsubsection{Aplicação dos questionários em professores universitários da FEF}

Fizemos a primeira explanação e apresentação dos questionários aos professores da FEF-UnB em uma reunião de conselho (Outubro, 2015), no qual apresentamos de forma rápida a relevância e os objetivos da pesquisa, bem como, falamos sobre a participação voluntária porém fundamental para nos ajudar a compreender os complexos fenômenos da saúde relacionada ao trabalho de docentes da Educação Física. Informamos sobre a garantia de sigilo das identidades, sobre nosso compromisso com o retorno dos resultados, e que o tempo estimado para o preenchimento dos questionários seria de 20 minutos. No mesmo dia, ao final da reunião, tivemos a devolução por parte dos professores de 12 questionários.

Como abordagem adicional aos professores não respondentes, deixamos cópias dos questionários no armário (escaninho) do professor. Essa informação, juntamente com uma cópia digital dos questionários e uma mensagem de sensibilização sobre a importância da pesquisa foram encaminhamos para o e-mail dos professores. Apresentamos os questionários e a forma de análise de seus dados a seguir.

No inicio do questionário obtemos informações gerais sobre os docentes da FEF tais como sexo, anos de docência no ensino superior, perspectiva das disciplinas que ministram (biológica e/ou técnica; ou social e/ou humana), se atuam na pós-graduação e se ocuparam cargos administrativos quantas vezes se ausentaram das atividades profissionais no ano de 2015 em decorrência de problemas de saúde e se a UnB já havia convidado para realizar algum exame de saúde (ANEXO III).

O Questionário Escala de Avaliação do Contexto de Trabalho teve sua primeira versão validada por Ferreira e Mendes (2003), tendo novas validações por Mendes (2007) e Ferreira e Mendes (2008). A versão atualizada do questionário utilizada na presente pesquisa (ANEXO IV) foi retirada de uma tese de doutorado orientada por Mendes, onde o contexto de trabalho é pensado a partir de três dimensões que se articulam: a organização do trabalho; as condições de trabalho; e as relações socioprofissionais (FACAS, 2013).

As opções de resposta aos 31 itens do questionário estão na forma de Escala Likert, variando de um a cinco pontos, onde: 1 igual a nunca; 2 a raramente; 3 a às vezes; 4 a 
frequentemente, e 5 a sempre. A particularidade do formato da Escala Likert é a ordinalidade não-ambígua das categorias de respostas. Quanto maior a pontuação, pior a percepção do contexto.

Os resultados foram apresentados em média e desvio padrão (DP) para o total de itens e separado nas três dimensões, conforme indicado pelos autores do questionário (FACAS 2013; FERREIRA; MENDES, 2008). A análise considerará as seguintes pontuações de corte:

- Abaixo de 2,3: Avaliação positiva, satisfatória, significa um resultado positivo, produtor de prazer no trabalho organizacional, aspecto a ser mantido e consolidado no ambiente organizacional.

- Entre 2,3 e 3,7: Avaliação moderada, crítica, representa um indicador de "situaçãolimite", sinalizando um estado de alerta que requer providencias a curto e médio prazo.

- Acima de 3,7: Avaliação negativa, grave, significa um resultado produtor de sofrimento, requerendo providencias imediatas nas causas, visando elimina-las ou atenua-las.

Em adição, foram feitas análises estratificando os resultados médios de cada uma das dimensões segundo características da amostra estudada (sexo, anos de docência no ensino superior, tipo de disciplina que ministra, se atua na pós-graduação, e se já ocupou algum cargo administrativo na UnB). Para essa análise quantitativa foi realizado o teste exato de Fischer, um teste mais indicado para o tamanho da amostra entre 20 e 40 sujeitos e com frequências $<1$.

O Questionário Cartão de Pontuação do Apoio à Saúde no Local de Trabalho, originalmente chamado de Worksite Health ScoreCard foi elaborado pelo Center for Disease Control e traduzido e adaptado por Soárez e Ciconelli (2013) tem 12 seções-tema que, em conjunto, formam o Índice de Ambiente de Trabalho Saudáveis. Na presente pesquisa foram utilizadas apenas três seções tema: suporte organizacional à promoção da saúde, à atividade física e ao gerenciamento de estresse. Segundo o estudo de validação (CDC, 2012; CDC, 2014) pode-se utilizar cada seção individualmente ou em diferentes arranjos ou momentos, sem necessidade de seguir a ordem estabelecida no questionário.

As respostas seguem o padrão de Sim ou Não e podem ser pontuadas de formas diferentes entre os itens variando de zero a três pontos, de acordo com o potencial impacto que a estratégia tem nos resultados ou comportamentos de saúde desejados e o peso da evidência científica que dá suporte a este impacto. É possível calcular a pontuação total com todas as dimensões e os pontos de cada um dos domínios específicos. 
Os resultados foram apresentados como média (DP) para o total de itens e separado para cada seção individualmente (suporte organizacional, atividade física e gerenciamento de estresse). A pontuação total do questionário pode variar de zero a 54 pontos. Quanto maior a pontuação, melhor a percepção de apoio.

Além da pontuação, fizemos a prevalência (\%) das avaliações que afirmam que o local de trabalho "não" oferece Suporte Organizacional à Promoção da Saúde, às Atividades físicas e ao Gerenciamento de Estresse, em cada das questões respondidas pelos docentes da FEF-UnB, 2016.

\subsubsection{A Entrevista com os professores universitários da FEF}

A parte qualitativa da pesquisa foi realizada entre novembro e dezembro de 2015, e utilizou a amostragem por saturação teórica, uma ferramenta conceitual frequentemente empregada nas investigações qualitativas que consiste em suspender a inclusão de novos participantes quando os dados obtidos passam a apresentar, na avaliação do pesquisador, certa redundância ou repetição, não sendo considerado relevante persistir na coleta de dados (FONTANELLA et al., 2008).

Dentre os professores que responderam aos questionários, alguns (sem seleção prévia) foram abordados no local de trabalho pela pesquisadora. Como já sabiam da realização da pesquisa, foi feita apenas uma sensibilização adicional e um convite para uma conversa de aproximadamente 30 minutos para o aprofundamento sobre o tema da pesquisa, em qualquer momento que fosse conveniente ao professor.

A maioria dos professores convidados aceitaram prontamente em participar da conversa e então a mesma foi agendada. No dia marcado, ao encontrar o professor buscou-se um local tranquilo para a conversa (em geral, na sala do professor). A seguir a pesquisadora explicou algumas informações sobre o processo da conversa na forma de entrevista e formalizou o convite à participação na pesquisa mediante apresentação e assinatura do TCLE. Por se tratar de um tema que envolve o contexto de trabalho e a conversa ser realizada no ambiente de trabalho, cuidado adicional foi tomado para informar ao professor a garantia do anonimato e que qualquer pergunta ou assunto que pudesse lhe deixar constrangido, ele poderia não responder ou até mesmo parar a entrevista.

Participaram da etapa qualitativa do estudo nove professores de Educação Física, seis homens e três mulheres. O roteiro de entrevista semiestruturada (APÊNDICE C) procurou identificar o conhecimento e as percepções (sentidos, significados e conceitos) sobre os temas 
e suas interrelações: situação de saúde e sua relação com o trabalho; o apoio institucional; o cuidar de si (em especial as práticas corporais e atividades físicas); e a promoção da saúde. Cabe destacar que o mesmo foi elaborado e analisado por três professoras doutoras especialistas no tema a respeito da forma e conteúdo, e testado em um estudo piloto para refinamento das perguntas e preparação da entrevistadora quanto aos procedimentos metodológicos de realização de entrevistas.

As entrevistas tiveram duração entre 10 e 25 minutos e foram gravadas através de um gravador de voz digital (SONY, IC Recorder, Quick Start Guide). Depois de gravadas e transcritas pela pesquisadora responsável, as entrevistas foram analisadas por meio da técnica de análise de conteúdo segundo Bardin (1977), de acordo com as seguintes etapas:

i. Pré-análise: leitura flutuante de todos os materiais para operacionalizar e sistematizar as ideias presentes no depoimento e a tomada de uma primeira decisão sobre quais deles efetivamente estão de acordo com os objetivos da pesquisa. Foi utilizada a técnica de colorir do editor de texto para organizar as unidades de análises (temas).

ii. Exploração do material: releitura cuidadosamente dos materiais e identificação das unidades de análise, elemento unitário de conteúdo a ser submetido posteriormente à classificação.

iii. Tratamento dos resultados e interpretação: agrupamento das unidades de análise de acordo com sua semelhança com o auxílio de planilhas eletrônicas. Em seguida, iniciou-se o processo de categorização, agrupando informações considerando a parte comum entre elas. A partir das sínteses coincidentes e divergentes e da interpretação inferencial as relações dos conteúdos foram estabelecidas.

A partir do referencial teórico, do desmembramento dos textos e do agrupamento analógico e o refinamento dos dados selecionados das falas dos entrevistados, tivemos como resultantes o agrupamento progressivo de quatro categorias iniciais, que resultaram na iminência das nove subcategorias e por fim, vários temas retirados da fala dos professores. 


\section{RESULTADOS}

\subsection{Caracterização do cenário de pesquisa: a FEF-UnB}

A pesquisa foi realizada na FEF-UnB, localizada no Campus Universitário Darcy Ribeiro, mais especificamente na Asa Norte às margens do Lago Paranoá. Nas proximidades temos os Clubes do Setor de Clubes Norte e a Casa do Estudante, a moradia disponibilizada pela UnB para os alunos de graduação de baixa renda. Geograficamente, a FEF fica afastada da área central da UnB (prédio da Reitoria, do Restaurante Universitário e da Biblioteca Central) e das demais Faculdades (Figura 8).

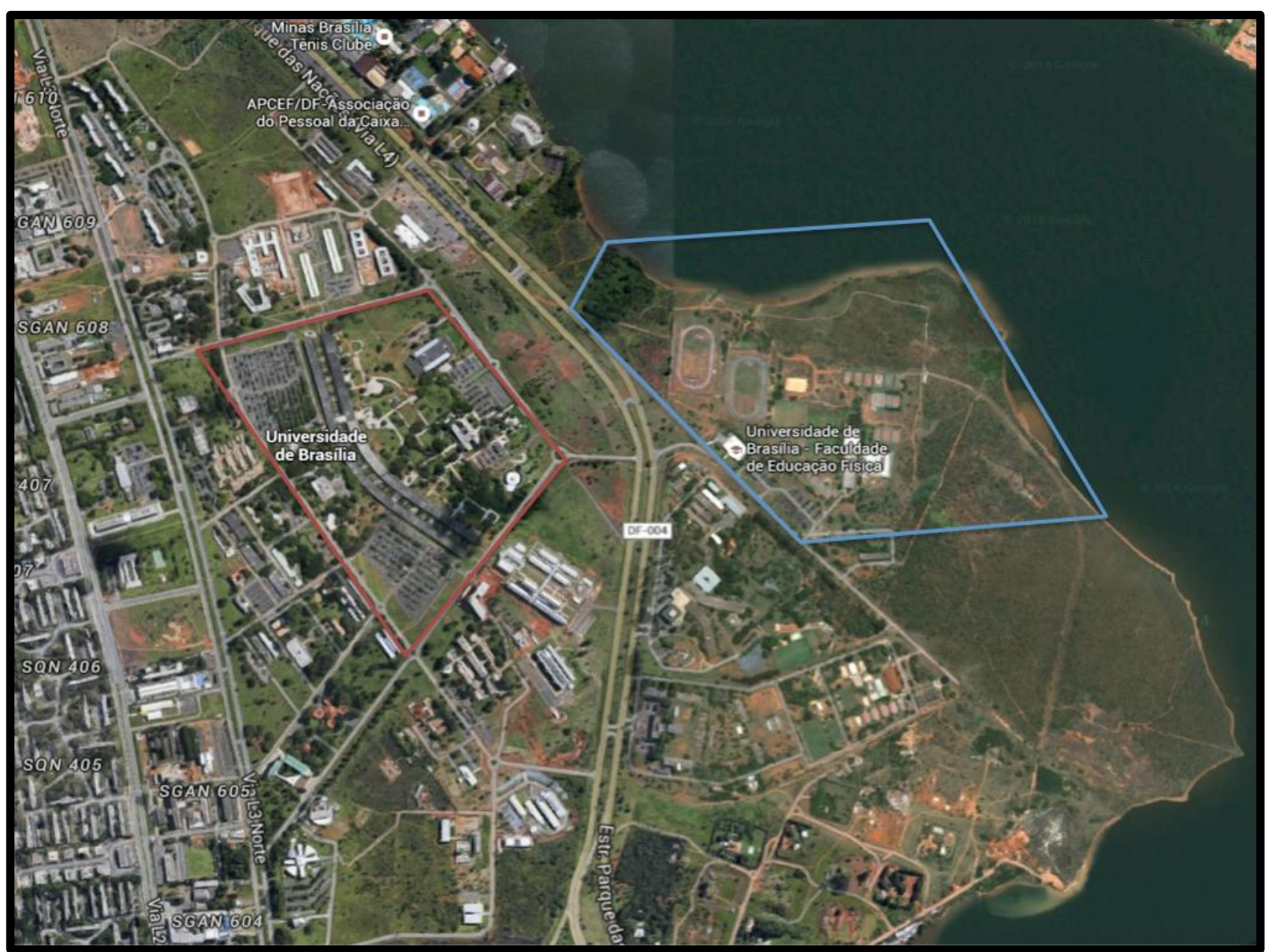

Figura 8. A área central da Universidade de Brasília (em vermelho) e a Faculdade de Educação Física. (em azul). Fonte: Google Maps (https://www.google.com.br/maps/).

Atualmente a FEF tem gestão administrativa própria (AZEVÊDO et al., 2004) e é composta pelo prédio da Faculdade em si, que abriga o espaço de ensino e administração, e abrange ainda o Centro Olímpico (Figura 9). A Faculdade possui amplo espaço verde e arborizado, estacionamento privativo para professores, sala de professores, secretarias, salas de reunião, lanchonete, banheiros, salas de aula e também laboratórios de fisiologia do 
exercício, avaliação da composição corporal e da aptidão física, cinesiologia, biomecânica, mídias, e educação física escolar e estudos do lazer. O Centro Olímpico contém pista de cross cerrado, pistas de atletismo, campos de futebol, quadra de vôlei de areia, ginásio polivalente, quadras externas multiuso, piscina olímpica e semi-olímpica, piscina de saltos ornamentais, sala de musculação, dojo, salas de aulas, sala de professores, e secretarias.

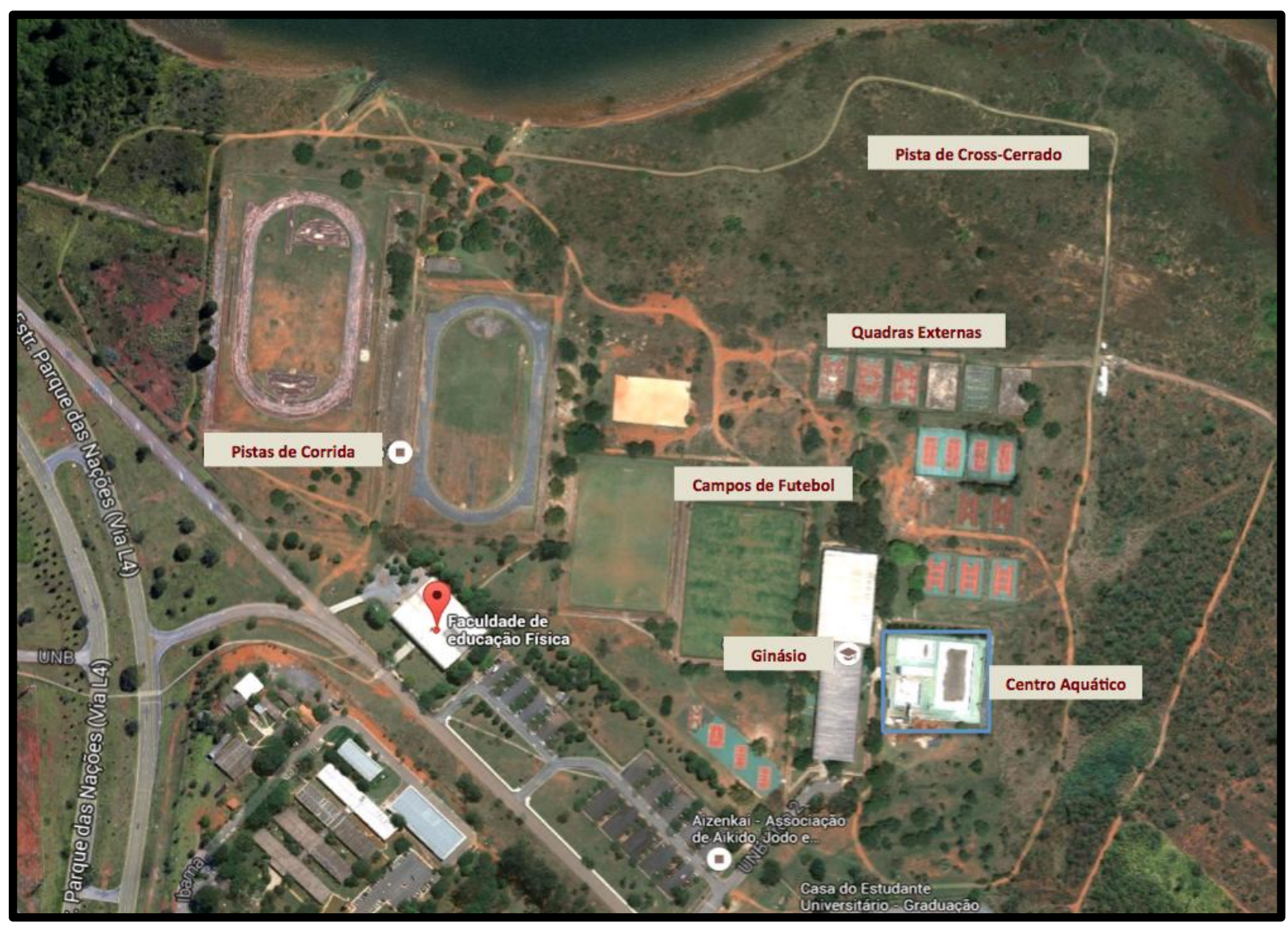

Figura 9. Faculdade de Educação Física, Universidade de Brasília. Fonte: Imagem do Google Maps (https://www.google.com.br/maps/)

Historicamente a FEF foi idealizada por professores de Educação Física funcionários da Divisão de Recreação e Esportes da Universidade. Esses professores desenvolviam atividades de treinamento de equipes desportivas e eram encarregados da oferta da disciplina prática desportiva para os estudantes da instituição. Analisando a condição que lhes era dada na Universidade, surgiu a ideia de criação do curso de Licenciatura em Educação Física em 1973, sendo autorizado posteriormente por meio do Ato da Reitoria $n^{\circ} 831$ (UnB, 1974a) e pela Reunião do Conselho Diretor $n^{\circ}$ 25/74 (UnB, 1974b) como um Departamento da Faculdade de Ciências da Saúde.

A Faculdade em si nasce em 1997 por meio da Resolução n. 002/97 do Conselho Universitário, que resolve: I extinguir o Departamento de Educação Física da Faculdade de 
Ciências da Saúde; II aprovar a criação da FEF, bem como sua estrutura organizacional provida de autonomia acadêmica, financeira e administrativa. Em 1998 é criado o Programa de Pós Graduação em Educação Física da FEF-UnB e aberto o primeiro curso de mestrado acadêmico. Em 2004 é criado o curso de doutorado.

Em 2008 é criado o curso de Licenciatura a distancia. Em 2012 é aprovado o curso de Bacharelado em Educação Física; visando formar um profissional com características diferentes dos que cursam a licenciatura. A licenciatura é mais voltada para a escola, enquanto o bacharelado visa formar o aluno para atuar em academias, clubes, parques e centros de saúde (UNB, 2011; PPP, 2011).

A cada semestre ingressam 100 alunos nos cursos de Licenciatura e Bacharelado presenciais na FEF-UnB. No segundo semestre de 2014, a FEF-UnB tinha 916 alunos regulares registrados na graduação presencial; 196 na licenciatura à distância; 80 alunos no mestrado e 12 alunos no doutorado (UNB, 2015). No segundo semestre de 2015, período de realização da pesquisa, a FEF-UnB contava com 46 docentes efetivos em seu quadro de professores; todos em regime de dedicação exclusiva. Considerando as características do corpo docente da FEF em 2015 (Tabela 1), podemos observar que este é composto majoritariamente por homens; que ministram disciplinas relacionadas às áreas biológicas e/ou técnicas; e que não atuam na pós-graduação. Praticamente metade dos professores entraram em uma IES nos últimos 10 anos e nunca ocupou um cargo administrativo.

\subsection{Etapa Quantitativa}

\subsubsection{Características da amostra estudada}

No referido período, oito professores estavam ausentes da FEF: três em gozo de licença capacitação e cinco afastados para realização de doutoramento ou estágio pósdoutoral. Desta forma, 38 professores foram considerados elegíveis para participar da presente pesquisa. Assim temos que a taxa de resposta aos questionários foi de 58\%; uma participação expressiva coerente com as três tentativas de sensibilização e coleta de dados empreendidas. As características dos professores elegíveis e da amostra estudada na primeira etapa da pesquisa também estão descritas na Tabela 1 . 
Tabela 1. Características da população da FEF-UnB, dos professores elegíveis e da amostra estudada na primeira etapa da pesquisa, realizada no segundo semestre de 2015.

\begin{tabular}{|c|c|c|c|c|c|c|c|c|}
\hline \multirow[t]{2}{*}{ Variável } & \multicolumn{2}{|c|}{$\begin{array}{c}\text { População FEF } \\
(n=46)\end{array}$} & \multicolumn{2}{|c|}{$\begin{array}{l}\text { Elegíveis } \\
(\mathrm{n}=38)\end{array}$} & \multicolumn{2}{|c|}{$\begin{array}{c}\text { Amostra } \\
(\mathrm{n}=\mathbf{2 2})\end{array}$} & \multirow{2}{*}{$\begin{array}{c}\text { Representatividade } \\
\text { da amostra }{ }^{\text {a }} \\
\%\end{array}$} & \multirow{2}{*}{$\begin{array}{c}\begin{array}{c}\text { Proporção da } \\
\text { população FEF }\end{array} \\
\%\end{array}$} \\
\hline & $\mathbf{N}$ & $\%$ & $\mathbf{N}$ & $\%$ & $\mathbf{n}$ & $\%$ & & \\
\hline Masculino & 34 & 73,9 & 27 & 71,0 & 15 & 68,2 & 55,6 & 44,1 \\
\hline Feminino & 12 & 26,1 & 11 & 29,0 & 7 & 31,8 & 63,6 & 58,3 \\
\hline$\geq 11$ & 24 & 52,2 & 20 & 52,6 & 16 & 72,7 & 80,0 & 66,7 \\
\hline \multicolumn{9}{|l|}{ Disciplinas que ministra } \\
\hline Biológicas e/ou técnicas & 28 & 60,9 & 24 & 63,2 & 13 & 59,1 & 54,2 & 46,4 \\
\hline Sociais e/ou humanas & 18 & 39,1 & 14 & 36,8 & 9 & 40,9 & 64,3 & 50,0 \\
\hline \multicolumn{9}{|c|}{ Ocupou cargo administrativo } \\
\hline Sim & 23 & 50,0 & 19 & 50,0 & 8 & 36,4 & 42,1 & 34,8 \\
\hline Não & 23 & 50,0 & 19 & 50,0 & 14 & 63,6 & 73,7 & 60,9 \\
\hline
\end{tabular}

${ }^{\mathbf{a}}$ Proporção de professores respondentes em relação aos elegíveis de acordo com cada variável; ${ }^{\mathbf{b}}$ Proporção de professores respondentes em relação ao total de professores da FEF-UnB de acordo com cada variável. 
Em termos de representatividade proporcional, os 22 docentes que responderam aos questionários conferem maior participação ao sexo feminino, com mais anos de docência no ensino superior, que ministram disciplinas na perspectiva social e/ou humana, que atuam na pós-graduação e que não ocuparam cargos administrativos (Tabela 1). Em adição, dos 22 docentes, 13,6\% reportaram haver se ausentado - entre uma a três das vezes - das atividades profissionais no ano de 2015 em decorrência de problemas de saúde. Quando questionados se a UnB já havia convidado para realizar algum exame de saúde, 40,9\% afirmaram que não; $36,4 \%$ informaram que sim e que haviam participado e $24,7 \%$ disseram que haviam sido convidados, mas não participaram.

\subsubsection{Análise do Questionário Escala de Avaliação do Contexto de Trabalho}

Ao analisar os dados do questionário Escala de Avaliação do Contexto de Trabalho em sua totalidade, temos que o valor médio (DP) obtido para os 31 itens e 22 professores foi de 2,9 (0,7) pontos, representando uma percepção de moderada à crítica do contexto de trabalho na UnB e sinalizando a necessidade de melhoras nesse contexto. Cabe destacar que três professores consideraram seu contexto de trabalho bastante negativo e dois professores que consideraram positivo.

Ao analisar o contexto com bases em suas três dimensões analíticas interdependentes, as pontuações médias (DP) foram: 3,0 $(0,5)$ para organização do trabalho, englobando os elementos prescritos que expressam as concepções e as práticas de gestão de pessoas e do trabalho presentes no contexto de produção; 3,0 $(0,8)$ para condições de trabalho, constituída pelos elementos estruturais que expressam as condições objetivas de trabalho, a infraestrutura e as práticas administrativas, tais como ambiente físico, posto de trabalho, equipamentos e materiais; e 2,8 $(0,8)$ para relações socioprofissionais, que versa sobre os elementos interacionais que expressam as relações de trabalho tais como as interações hierárquicas, coletivas, intra e intergrupos, e externas; uma avaliação ligeiramente melhor (mas não estatisticamente diferente) que as demais dimensões.

Ao analisar os resultados segundo características da amostra estudada (Tabela 2), identificamos algumas tendências de pior percepção do Contexto de Trabalho por professores que ministram disciplinas sociais e/ou pedagógicas; que atuam na pós-graduação e que ocupam cargos administrativos. Não houve diferenças estatisticamente significativas $(p<0,05)$ nas pontuações médias por sexo e anos de docência. 
Tabela 2. Escala de avaliação do contexto de trabalho com bases em suas três dimensões analíticas e de acordo com características da amostra de docentes da FEF-UnB.

\begin{tabular}{|c|c|c|c|c|c|c|}
\hline \multirow{2}{*}{$\begin{array}{ll} & \text { Variável } \\
\text { Sexo }\end{array}$} & \multicolumn{2}{|c|}{$\begin{array}{l}\text { Organização } \\
\text { do trabalho }\end{array}$} & \multicolumn{2}{|c|}{$\begin{array}{c}\text { Relações } \\
\text { socioprofissionais }\end{array}$} & \multicolumn{2}{|c|}{$\begin{array}{l}\text { Condição } \\
\text { de Trabalho }\end{array}$} \\
\hline & $\mathbf{M}$ & $\mathrm{DP}$ & $\mathbf{M}$ & DP & $\mathbf{M}$ & $\mathrm{DP}$ \\
\hline Masculino $(n=15)$ & 3.0 & 0.5 & 2.8 & 0.7 & 3.0 & 0.7 \\
\hline Feminino $(n=7)$ & 2.9 & 0.5 & 2.9 & 1.0 & 3.1 & 1.0 \\
\hline \multicolumn{7}{|l|}{ Anos de docência } \\
\hline 1 a $10(n=6)$ & 3.0 & 0.1 & 2.7 & 1.0 & 3.2 & 0.5 \\
\hline$\geq 11(\mathrm{n}=16)$ & 3.0 & 0.6 & 2.8 & 0.7 & 3.0 & 0.9 \\
\hline \multicolumn{7}{|l|}{ Disciplinas que ministra } \\
\hline $\begin{array}{l}\text { Biológicas ou técnicas } \\
(\mathrm{n}=13)\end{array}$ & 2.8 & 0.3 & 2.6 & 0.8 & 2.9 & 0.7 \\
\hline Sociais ou humanas $(n=9)$ & $3.3^{*}$ & 0.6 & $3.1 *$ & 0.6 & 3.2 & 0.9 \\
\hline \multicolumn{7}{|l|}{ Atua na pós-graduação } \\
\hline $\operatorname{Sim}(n=9)$ & 3.1 & 0.4 & 2.7 & 0.9 & $3.3^{*}$ & 0.7 \\
\hline Não (n=13) & 2.9 & 0.6 & 2.9 & 0.7 & 2.8 & 0.8 \\
\hline \multicolumn{7}{|c|}{ Ocupou cargo administrativo } \\
\hline $\operatorname{Sim}(n=8)$ & 3.2 & 0.5 & 3.1 & 0.5 & 3.0 & 0.8 \\
\hline Não (n=14) & 2.9 & 0.4 & 2.7 & 0.9 & 3.1 & 0.8 \\
\hline
\end{tabular}

Podemos perceber diferença estatisticamente significativa na pontuação em algumas dimensões do contexto de trabalho ao comparar os professores de acordo com a abordagem das disciplinas que ministram. Professores das abordagens sociais ou humanas tendem ter uma percepção pior do contexto de trabalho em todas as dimensões. Atuar na pós-graduação também resultou em uma pior percepção das condições de trabalho de forma estatisticamente significativa. Embora sem significância estatística, aqueles que ocuparam cargos administrativos tendem a ter pior percepção da organização do trabalho e das relações socioprofissionais. 


\subsubsection{Análise do Questionário de Saúde no Ambiente de Trabalho}

Dos 54 pontos possíveis de se obter no cartão de pontuação do apoio à saúde no local de trabalho, as respostas dos professores da FEF-UnB obtiveram uma média de 32 pontos (59,3\% do total). Quando cada seção foi analisada separadamente, os resultados foram: 6 de 16 pontos possíveis $(37,5 \%)$ para suporte organizacional em promoção da saúde; 20 de 24 pontos $(83,3 \%)$ para atividade física; e 6 de 14 pontos possíveis (42,9\%) para gerenciamento de estresse.

Outra forma de olhar esses dados foi quanto à prevalência de professores que afirmam que o local de trabalho NÃO oferece Suporte Organizacional em Promoção da Saúde $(80,3 \%)$, Atividades físicas $(59,1 \%)$ e Gerenciamento de Estresse $(75,8 \%)$.

Ao analisar as prevalências de respostas a cada uma das nove perguntas da seção suporte organizacional à Promoção da Saúde temos que a maioria dos professores responderam que a UnB NÃO oferece suporte organizacional à maioria das variáveis investigadas, com exceção da última, que se refere políticas de horários flexíveis (quadro 2).

Quadro 3. Prevalência de professores da FEF que responderam que a UnB "NÃO" ofereceu suporte organizacional à Promoção da Saúde, em cada uma das nove questões.

\begin{tabular}{|c|l|}
\hline$\%$ & \multicolumn{1}{|c|}{ A UnB NÃO ofereceu Suporte Organizacional à Promoção da Saúde } \\
\hline 95,3 & $\begin{array}{l}\text { Demonstrou apoio e comprometimento organizacionais voltados à promoção da saúde no } \\
\text { local de trabalho em todos os níveis hierárquicos }\end{array}$ \\
\hline 95,3 & $\begin{array}{l}\text { Conduziu avaliações contínuas da programação de promoção da saúde com a utilização } \\
\text { de diferentes fontes de dados }\end{array}$ \\
\hline 90,5 & $\begin{array}{l}\text { Avaliou interesses e necessidades dos funcionários para planejar atividades de promoção } \\
\text { da saúde }\end{array}$ \\
\hline 85,7 & $\begin{array}{l}\text { Usou incentivos combinados a outras estratégias, para aumentar a participação em } \\
\text { programas de promoção da saúde }\end{array}$ \\
\hline 85,7 & Promoveu e divulgou programas de promoção da saúde para seus funcionários \\
\hline 85,7 & Disponibilizou algum programa de promoção da saúde para familiares de funcionários \\
\hline 76,2 & $\begin{array}{l}\text { Adaptou programas de promoção da saúde e materiais educativos à língua, ao grau de } \\
\text { instrução e à cultura dos diferentes segmentos da força de trabalho }\end{array}$ \\
\hline 71,4 & $\begin{array}{l}\text { Participou de outras iniciativas voltadas à saúde na comunidade e apoiou a participação } \\
\text { de funcionários e o trabalho voluntário }\end{array}$ \\
\hline 47,6 & Implantou políticas de horários de trabalho flexíveis \\
\hline
\end{tabular}

Quanto às nove perguntas relacionadas ao fomento da atividade física no local de trabalho temos que apenas uma minoria identifica que a UnB disponibilize atividades informacionais, educativas ou de avaliação física. Não obstante, a maioria dos docentes 
identifica que a UnB disponibiliza instalações para a prática; que organiza alguns programas; e que oferta algum outro tipo de apoio (Quadro 3).

Quadro 4. Prevalência de professores da FEF que responderam que a UnB "NÃO" ofereceu suporte organizacional à Atividade Física, em cada uma das nove questões.

\begin{tabular}{|c|c|}
\hline$\%$ & A UnB NÃO ofereceu Suporte Organizacional à Atividade Física \\
\hline 95,3 & $\begin{array}{l}\text { Colocou avisos em elevadores, portas de acesso às escadas e outros locais-chave, } \\
\text { estimulando os funcionários a utilizar as escadas }\end{array}$ \\
\hline 90,5 & $\begin{array}{l}\text { Realizou ou subsidiou avaliações de condicionamento físico, aconselhamento, } \\
\text { acompanhamento ou indicação de atividades físicas no local de trabalho ou em } \\
\text { instalações comunitárias para prática de exercícios }\end{array}$ \\
\hline 90,5 & Disponibilizou programas de autogerenciamento de atividade física \\
\hline 85,7 & $\begin{array}{l}\text { Distribuiu folhetos, vídeos, cartazes, panfletos, informativos ou outras informações em } \\
\text { papel ou online que tratassem dos benefícios da atividade física }\end{array}$ \\
\hline 57,2 & Realizou algumas aulas, oficinas ou seminários educativos sobre atividade física \\
\hline 42,9 & $\begin{array}{l}\text { Proporcionou programas organizados para prática de atividades físicas individuais ou } \\
\text { em grupo para funcionários }\end{array}$ \\
\hline 33,3 & $\begin{array}{l}\text { Subsidiou ou deu descontos no uso de instalações para prática de atividade física no } \\
\text { local de trabalho ou fora dele }\end{array}$ \\
\hline 28,6 & Disponibilizou outros tipos de suporte à atividade física ou recreativa \\
\hline 9,5 & Disponibilizou instalações para a prática de atividade física no local de trabalho \\
\hline
\end{tabular}

Por fim, a maioria dos professores responderam que a UnB NÃO oferece suporte organizacional ao gerenciamento de estresse nas perguntas desta seção (Quadro 4).

Quadro 5. Prevalência de professores da FEF que responderam que a UnB "NÃO" ofereceu suporte organizacional ao gerenciamento de estresse, em cada uma das seis questões.

\begin{tabular}{|c|l|}
\hline$\%$ & \multicolumn{1}{|c|}{ A UnB NÃO ofereceu Suporte Organizacional ao Gerenciamento de Estresse } \\
\hline 90,5 & Disponibilizou programas de gerenciamento de estresse? \\
\hline 85,7 & $\begin{array}{l}\text { Proporcionou aos gerentes treinamento para identificar e reduzir questões relacionadas } \\
\text { ao estresse no local de trabalho? }\end{array}$ \\
\hline 76,2 & $\begin{array}{l}\text { Proporcionou oportunidades para que funcionários participassem das decisões } \\
\text { organizacionais envolvendo questões que afetem o estresse no local de trabalho? }\end{array}$ \\
\hline 71,4 & $\begin{array}{l}\text { Ofereceu programas sobre competência pessoal ou equilíbrio do trabalho e vida } \\
\text { pessoal? }\end{array}$ \\
\hline 61,9 & $\begin{array}{l}\text { Proporcionou espaços específicos para os funcionários realizarem atividades de } \\
\text { relaxamento, tais como meditação, yoga, ou biofeedback? }\end{array}$ \\
\hline 52,9 & Patrocinou ou organizou eventos sociais ao longo do ano? \\
\hline
\end{tabular}




\subsection{Análise da Etapa Qualitativa}

\subsubsection{Características dos participantes das entrevistas}

Participaram da etapa qualitativa do estudo nove professores de Educação Física, seis homens e três mulheres, sendo expressivamente mais experientes e que nunca ocuparam cargos administrativos; a divisão foi mais equânime quanto ao tipo de abordagem nas disciplinas que ministram e se atua na pós-graduação (Tabela 3).

Tabela 3. Características gerais dos docentes participantes da etapa qualitativa da pesquisa na FEF-UnB; 2015.

\begin{tabular}{lccc}
\hline & Variável & \multicolumn{2}{c}{ Amostra (n=9) } \\
\hline Sexo & $\mathbf{N}$ & \% \\
Masculino & 6 & 66,7 \\
Feminino & 3 & 33,3
\end{tabular}

Anos de Docência no Ensino Superior

1 a 10 anos

2

$\geq 11$ anos

7

77,8

\section{Disciplinas que ministra}

Biológicas e/ou Técnicas

5

Sociais e/ou Humanas

4

Atua na Pós-Graduação

Sim

4

Não

5

55,6

Ocupou cargo administrativo

Sim

Não

7

77,8

\subsubsection{Análises das entrevistas}

Em geral as entrevistas transcorreram de forma tranquila, tiveram duração entre 10 a 25 minutos, e foram realizadas nas salas de cada professor ou nas salas de aula com a porta encostada. Em apenas uma das entrevistas realizadas em sala de aula da FEF, o professor foi interrompido por um aluno e em outra, realizada na sala dos professores da FEF houve a interrupção por outro professor. As interrupções não trouxeram prejuízos para as entrevistas, somente uma pausa na gravação. 
Em consonância com os referenciais teóricos adotados, sistematizamos (Figura 10) a percepção dos professores sobre quatro categorias com complexas interrelações: i) a saúde, em termos de sua situação (Positiva ou Negativa), de suas esferas (Física, Mental, Emocional, Espiritual, e/ou Integral) e de sua relação com o contexto de trabalho na universidade e com o autocuidado; ii) o contexto de trabalho, incluindo as possibilidades promotoras de saúde que a universidade oferece; iii) o autocuidado, seja ele apoiado institucionalmente e/ou uma iniciativa individual do cuidar de si; e iv) a percepção sobre a promoção da saúde, como um conceito que norteia os discursos e as práticas relatadas. A opção por apresentar seus resultados em separado é metodológica para facilitar o detalhamento de cada um dos itens.

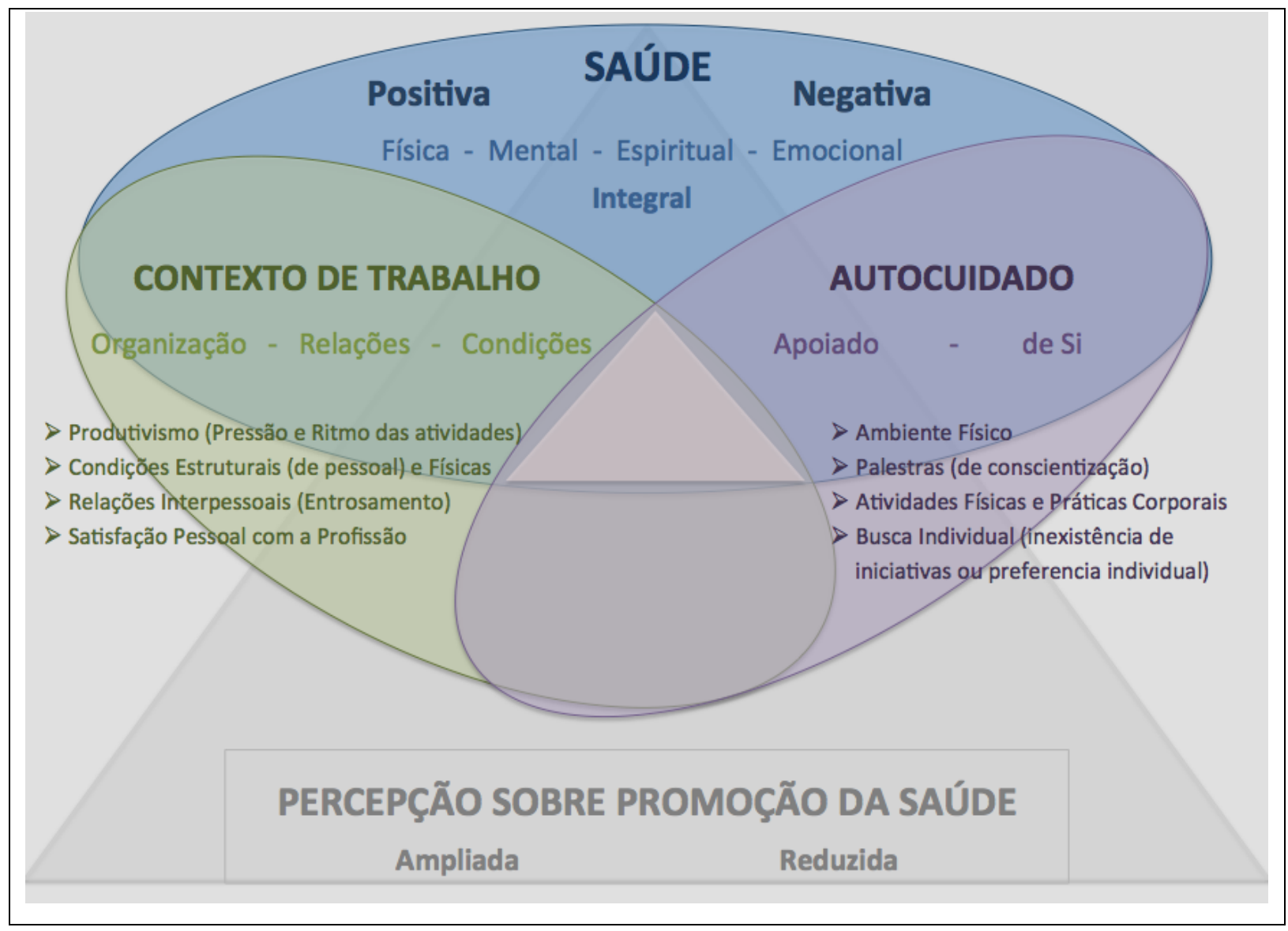

Figura 10. Modelo esquemático de categorias analíticas do estudo e suas interrelações. Fonte: Autora.

De forma geral, os professores entrevistados da FEF-UnB descrevem interrelações entre a saúde, o trabalho e o cuidar de si, de forma que um modelo dual e linear não é capaz de explicar. A maioria dos docentes aponta aspectos positivos e negativos para cada categoria e subcategoria analisadas, onde os aspectos e temas identificados ora contribuem com a saúde (em uma ou em múltiplas dimensões), ora contribuem com o adoecimento, dependendo do 
contexto em que se encontram. Da mesma forma, os discursos ora se embasam em visões mais específicas de saúde (e de sua promoção), ora apresentam olhares ampliados sobre o fenômeno, de forma a reforçar os aspectos mais macros ou mais individuais que buscavam destacar. A seguir exploraremos cada uma das categorias isoladamente para, na sequencia, retomarmos suas inter-relações, possibilitando a construção de um mosaico ao qual vamos adicionando elementos a cada etapa de análise.

\subsubsection{Percepção dos professores sobre a Situação Saúde}

A percepção dos professores sobre a saúde em termos de sua situação apresenta aspectos positivos e negativos relativos às dimensões física, mental (cognitiva), espiritual e emocional ou ainda, a uma dimensão mais integral da mesma, quando os professores relatam diversas dimensões conjuntamente (Figura 11).

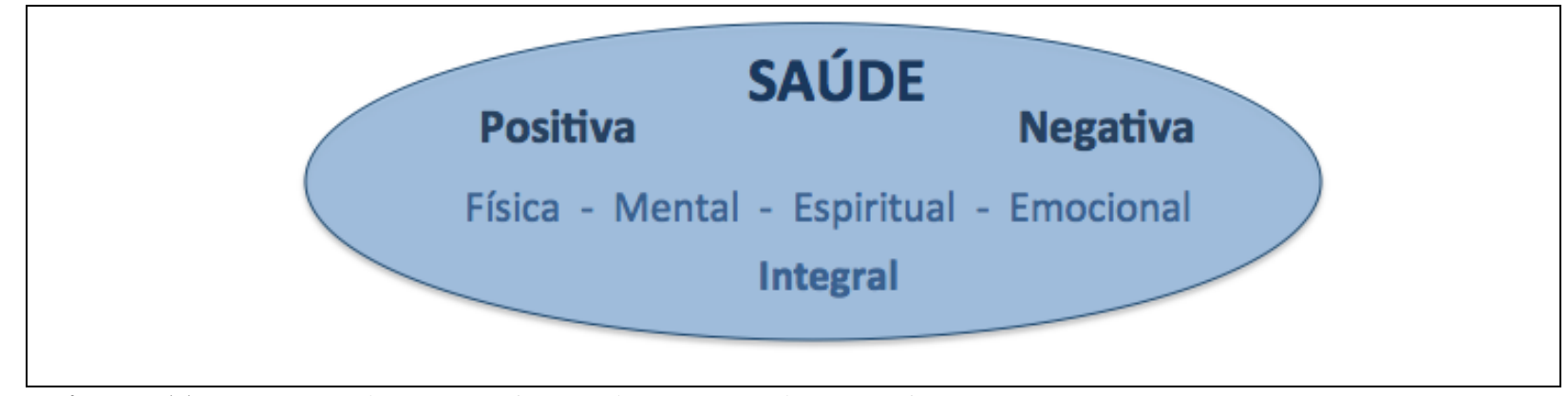

Figura 11. Esquema da Categoria Saúde e suas Subcategorias. Fonte: Autora

Quase a totalidade dos professores entrevistados $(n=8)$ relataram algum aspecto negativo de sua saúde, principalmente nas esferas física e emocional. Alguns termos (unidades de registro) que apareceram nas falas e foram classificados como indicadores negativos de saúde são: problemas crônicos; adoecimento; restrições; imunidade baixa; gripe; indisposição; dores; redução da flexibilidade; sobrepeso; cansaço geral; idade; estresse; dificuldade para dormir; e ansiedade. Vejamos a seguir os termos destacados nos contextos das falas:

P1- "Um aspecto é de estresse, cansaço... que, por sua vez... é... acarretam algumas baixas de imunidade" $[\ldots]$ "Eu me sinto [...] assim... é... tenho dores de garganta ou alguma indisposição ... é o mais constante!". [...] "Eu me sinto com a saúde mediana, eu não acho que eu esteja no auge da saúde, não!...”.

P3- "Eu sinto que a minha saúde... é... devido à minha idade, ela está boa, mas ela já está não está como era antes, como há vinte anos atrás! Então, eu sinto que a 
minha saúde está numa descendente. Alguns problemas crônicos vão acontecendo ao longo do tempo, devido a idade! Então, daí um pouco vai começando a ter artrose, diminui a flexibilidade, sobrepeso...".

P5- "Eu me sinto bem, assim, se considerar o parâmetro cronológico e a idade. É óbvio que se você fizer uma comparação, você vai ver que existe uma série de restrições em relação à parte física...".

P7- "Eu estou bastante cansado! Tenho tido uma regular dificuldade para dormir! Então, eu estou, assim, ansioso, quero o final do semestre letivo para poder recuperar um pouco da minha energia! Às vezes, falta energia... É esse cansaço geral, assim... vontade de descansar!".

P8- “...Eu estou com um problema já há alguns anos de uma secreção constante que é produzida aqui nos seios da face, e eu tenho lidado com isso e tenho, buscado aí descobrir o que é...” [...] "E realmente ontem eu comecei a me sentir baqueado, eu dei uma gripada que me deu uma baqueada...".

É interessante notar que os professores, ao relatar as queixas sobre sua saúde muitas vezes modificavam a fisionomia e a entonação da voz no sentido de demonstrar ou dar ênfase ao cansaço e à falta da disposição.

Não obstante, três professores também fizeram questão de destacar percepções positivas quanto à sua situação de saúde. Na perspectiva positiva de saúde os relatos abrangiam conjuntamente termos relativos à diversas esferas (física, mental, espiritual e emocional) da saúde, se aproximando mais de uma perspectiva integral, como podemos observar nas falas a seguir:

P2- "A parte, digamos física, perfeita, me sinto super bem; saúde mental, muito bem... é... a parte social, vida social, também perfeita! Então, eu estou com a saúde excelente!..."

P8- “ Tenho minha vida espiritual! Tenho a minha vida social! E estamos aí nessa caminhada! Em busca da saúde plena!...”

P9- "Se a gente pensar, na saúde como uma ausência de doença, a minha saúde vai muito bem! Não tenho nenhuma doença! Não tenho nenhuma dor. [...] No entanto, eu acho que a saúde, ela tem a ver com a produção criativa da vida. O que envolve tanto as nossas condições subjetivas como as nossas condições objetivas!

Sobre a situação de saúde em sua perspectiva positiva cabe destaque à dois professores que efetivamente mencionaram uma concepção ampliada do fenômeno ao utilizar termos como: saúde plena; produção criativa da vida; condições objetivas e subjetivas para sua produção. É interessante notar que ambos utilizaram uma voz mais suave e calma neste 
momento para falar do fenômeno, além de um deles deslocar o olhar para o horizonte como se estivesse vislumbrando a plenitude. Dois professores (P8 e P9) fazem da parte da área Sociais, Humanas e/ou Pedagógicas e um professor (P2) da área Biológicas e/ou Técnicas.

\subsubsection{Percepção dos professores sobre a Relação entre Saúde e Trabalho}

Conforme mostramos a seguir, os professores percebem uma clara relação de sua situação de saúde com o trabalho docente na FEF-UnB. Aspectos negativos dessa relação foram destacados pela utilização de termos como: produtivismo (pressão e ritmo das atividades); relações interpessoais (falta de entrosamento e tensionamentos); e condições estruturais (de pessoal e físicas); como mostram as falas a seguir:

P1- "Eu acho que, principalmente, algum aspecto na saúde é de estresse, cansaço, de... um ritmo de trabalho excessivo que, por sua vez...[acarretam problemas físicos]" [...] "O ritmo de atividades, principalmente as que envolvem a parte administrativa, tem sido bastante grandes e carregadas também não só de tarefas, mas carregadas de tensões intrínsecas aos grupos aqui da Faculdade, o que tem sido bastante desgastante".

P9- "[...]a Universidade está cada vez mais rigorosa que nos constrange ao produtivismo. [...] Então eu acho que é uma determinação de adoecimento hoje: as metas de produtividade que são colocadas por nosso trabalho. Isso no campo da pesquisa!

P6- "O desgaste que o professor tem maior é, muitas vezes, as questões, assim, talvez, de entrosamento. Eu não me desgasto tanto com isso, mas vejo que alguns colegas... tem um certo sofrimento com as dificuldades, de você aí fazer esse relacionamento social; alguns colegas tem umas posturas mais rígidas ou mais personalísticas, e aí, às vezes, eles não se entendem muito bem aí e ficam se desgastando!".

P7- "[...] um elemento estressor aqui é a precariedade das condições de trabalho! Então, se está muito quente, eu não tenho uma sala refrigerada e suo enquanto estou tentando pensar na minha pesquisa; é... não tem isolamento acústico [...] então, a todo instante eu estou ouvindo gente, eu não consigo ficar num ambiente quieto". [...] "Pior do que isso ainda é a internet, que é uma vergonha - então, eu não tenho internet e isso é uma das coisas que me deixa mais furioso! Então, isso me adoece....".

P8- "Eu acho que a principal coisa [adoecedora] seria as relações interpessoais de trabalho, porque, de um modo geral, elas não são muito fraternas, elas são... não é uma guerra, mas não são fraternas, sabe?! Normóticas! Você já ouviu falar desse termo? Normótico? E, na verdade, também tem muita dificuldade de comunicação, de interação, Sobretudo entre professores, mas também entre professores e funcionários...". 
P9- "Então, sob o ponto de vista subjetivo, eu acho que as condições ou os determinantes sociais que envolvem o mundo do trabalho, eles colocam para gente hoje uma pressão muito grande, o que nos traz limitações para viver plenamente a vida no sentido do desenvolvimento das nossas múltiplas capacidades. Isso porque a gente tem que levar trabalho para casa nos finais de semana, levar trabalho de vocês [alunos da pós-graduação] para corrigir...".

Aspectos positivos dessa relação entre trabalho e saúde também emergiram das falas dos professores, representados pela satisfação com a profissão, incluindo aspectos de organização e condições de trabalho e as relações socioprofissionais. Termos relacionados à saúde emocional (como felicidade, paixão, prazer, gostar, bom entrosamento); e à saúde mental (como conhecimentos, consciência, satisfação e permanecer ativa) foram bastante frequentes ao descrever essa relação, conforme observamos a seguir:

P1- "Assim: eu gosto muito do que eu faço, principalmente, a parte de ser professora! Eu gosto muito![trabalho]".

P2- “[...] fica tudo certo quando você trabalha naquilo que você tem paixão... prazer. Eu sou doente por dar aula! Eu adoro dar aula! Doente no bom sentido! [RISOS] Então, assim: para mim é uma satisfação maior do mundo! Eu me divirto trabalhando... [trabalho]."

P3- "O trabalho não prejudicou a minha saúde! Eu não tenho nada a dizer, assim, contra o trabalho! Não me prejudicou a saúde! Até me manteve mais ativa! O meu trabalho até ajudou a promover a minha saúde, porque tudo o que eu li, tudo o que eu aprendi... é... então, me deu bastante consciência do que eu podia fazer para melhorar a minha saúde; garantir um pouco mais a minha saúde!”

P6- "Tenho um ambiente de trabalho relativamente tranquilo, na medida, com bom entrosamento com os colegas... Então, eu considero que tenho uma boa saúde!”.

P7- "Bem! Eu sou muito feliz fazendo o que eu faço! Eu gosto demais! Então, eu acho que isso me permite colocar muita energia nas coisas que eu faço, porque eu faço com muito prazer! Eu dou aula com muito prazer! Faço pesquisa com muito prazer! [trabalho]."

P8- "É muito bom! O local que eu trabalho... O que eu faço... é... eu não tenho dúvida que é algo que me realiza e que, consequentemente, traz qualidade de vida!". [...] "E o trabalho em termos de organização de tempo, de espaço, favorece que eu cuide... que eu possa cuidar da minha saúde, me dá tempo para cuidar da minha saúde...”.

Mais uma vez fica claro que os indivíduos apontam aspectos promotores do adoecimento em seu trabalho, mas também destacam aspectos promotores da sua saúde nesse 
contexto profissional, o que indica a necessidade de um olhar complexo sobre essas interações. Não se trata de definir o contexto de trabalho como uma coisa ou outra; o trabalho oferece ambas as possibilidades ao mesmo tempo. Exploraremos mais sobre essa categoria do contexto de trabalho a seguir.

\subsubsection{Percepção dos professores sobre o Contexto de Trabalho}

No contexto do trabalho, conforme vimos anteriormente, temos três subcategorias que se destacam: a organização do trabalho; as relações socioprofissionais; e as condições de trabalho (Figura 12). Ao buscar identificar a percepção dos professores sobre esse contexto, emergem de maneira bastante frequente termos relacionados: à estrutura organizacional (terceirização, rotatividade e baixa qualidade de pessoal) e produtivismo (pressão e ritmo das atividades); aos relacionamentos pessoais (consigo mesmo, e com colegas, funcionários e alunos); e ao ambiente físico da Universidade.

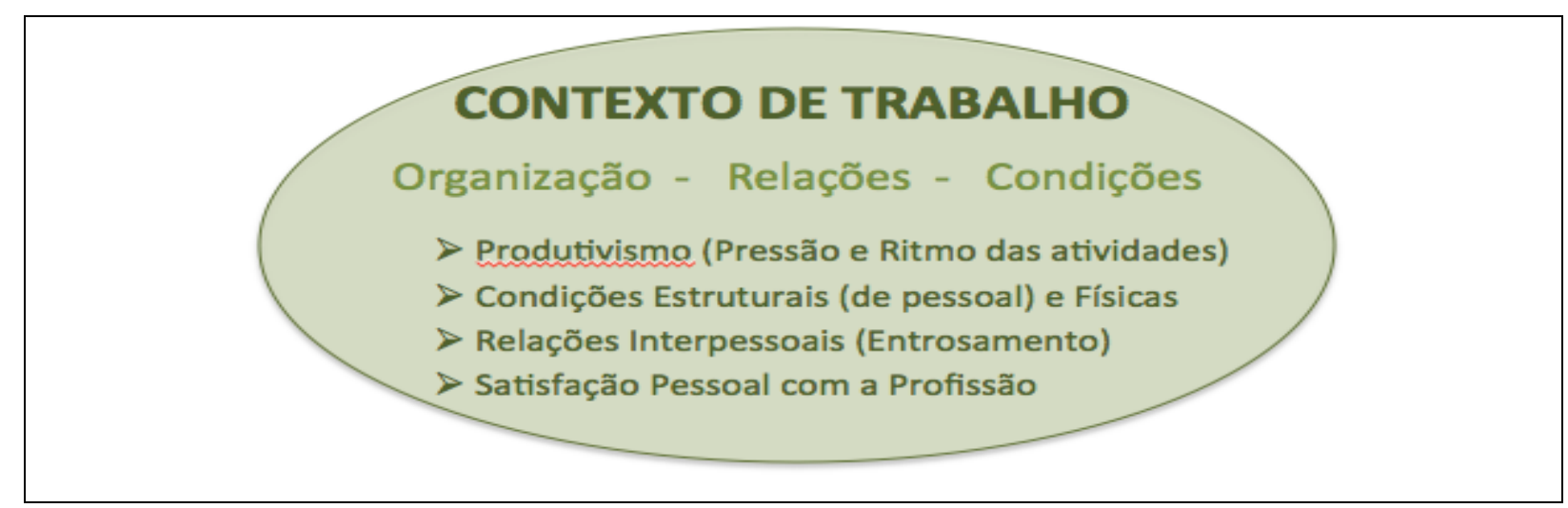

Figura 12. Esquema da Categoria Contexto de Trabalho e suas Subcategorias. Fonte: Autora

Vejamos as falas a seguir sobre a organização do trabalho, onde são destacados aspectos negativos dessa subcategoria:

P1- "Processo de adoecimento aqui é a estrutura organizacional do trabalho. A estrutura física, ela não é também a estrutura ideal, mas, pelo menos para mim, não nesse momento, ela não me parece causadora de adoecimento..." [...] "O ritmo de atividades, principalmente as que envolvem a parte administrativa, tem sido bastante grandes e carregadas também não só das tarefas, mas carregadas de tensões intrínsecas aos grupos aqui da Faculdade, o que tem sido bastante desgastante."[...] "E a estrutura organizacional, ela desgasta demais o servidor porque a Universidade é atualmente sucateada! A gente tem servidores terceirizados prestando serviços e, muitas vezes, essas pessoas não tem a 
qualificação adequada ou, então, não tem o incentivo adequado; a rotatividade de pessoal é muito grande; e faz com que o professor, ele acaba tendo que acumular diversas funções! O professor, ele não só é professor e pesquisador, como também tem que ter características de administrador e fazer trabalho, muitas vezes, dos servidores técnico-administrativos, que por uma razão ou outra, seja pela rotatividade ou falta de interesse...é...não cumprem com as funções de forma desejada! Então, essa estrutura, que tá bastante precarizada. Eu diria: é a que vem causando a maior chance de adoecimento...".

P6- "[...] o que a gente tem é, às vezes, uma dificuldade em cumprir as metas de produtividade, que tão definidas no meio acadêmico, pela forma como a gente organiza o tempo e pelo caráter produtivista que tem a avaliação [de carreira]. Então, eu ainda, por exemplo, estou fora dos parâmetros considerados desejados pela Universidade". [...] "É muito difícil! Na Universidade, em particular, eu sofria mais quando eu estava na administração, porque aí eu dependia de muitas coisas na Reitoria, de muitas coisas em outros setores! E aí, você depara com isso que não é só aqui na Educação Física! Você depara com isso na Universidade inteira. E aí, ...você não consegue que os seus processos andem; não consegue que as compras sejam feitas; não consegue pagar as pessoas; não consegue usar o dinheiro que você conseguiu a tanto custo e você tem que devolver...Então, quando você passa por essas coisas, elas são todas desgastantes, Muito desgastantes!” .

P9- "[...]a Universidade está cada vez mais rigorosa que nos constrange ao produtivismo. [...] Então eu acho que é uma determinação de adoecimento hoje: as metas de produtividade que são colocadas por nosso trabalho. Isso no campo da pesquisa! No campo do ensino eu acho que há também algo que nos afeta psicologicamente, que é um pouco da frustração com o processo ensinoaprendizagem." [...] "Eu acho que o adoecer que o professor vive hoje é psíquico. A pressão do trabalho: da produção, de dar respostas! Hoje, a gente passa por um processo de avaliação para progressão na carreira que se dá por pontos que se traduzem, ao fim e ao cabo, por metas de produtividade que são ou bianuais ou quadrienais." [...] "Eu percebo que essas condições de trabalho hoje são muito aceleradas, elas nos roubam muito tempo! Um tempo em que a gente podia se dedicar à família! Um tempo em que a gente podia se dedicar a cuidar mais da gente! A gente se sente pressionado. A gente se sente culpado por gozar o tempo...”.

Não obstante, um aspecto dessa subcategoria (organização do trabalho) foi considerado por muitos professores como um aspecto positivo: a flexibilidade do horário de trabalho, como podemos verificar a seguir:

P2- [...] O bom do meu trabalho aqui, que a gente é dedicação exclusiva... O horário para escrever artigo, para pesquisar, a gente consegue remanejar horários. "A instituição [UnB], um dos pontos muito positivos aqui é que ela proporciona isso para o professor!

P5- "[...] A Universidade tem um potencial enorme para essa questão de trabalhar a qualidade de vida... É... Em termos de estrutura e em termos de flexibilidade no 
horário. Mas ela poderia ter esse potencial aumentado! Eu acho que ela não é proativa nesse sentido! Por isso que eu acho que ela deixa a desejar nesse sentido! Mas, em relação ao que eu falei: flexibilidade e horário, ela é fantástica!”.

P8- "[...] O trabalho em termos de organização de tempo, de espaço, favorece que eu cuide... que eu possa cuidar da minha saúde, me dá tempo para cuidar da minha saúde...".

E cabe destacar que, de forma singular, um dos professores aponta a produtividade como um aspecto positivo da organização do trabalho na relação com sua saúde, e esse professor é da área Biológicas e/ou Técnicas.

P4- "Então, para mim, produtividade, eu não acho que... que a demanda e a cobrança seja muito grande, fora do esperado do professor universitário... Isso, para mim, não é fator de stress, adoecimento, nada disso! Ao contrário! Eu acho até um desafio!".

$\mathrm{Na}$ subcategoria de relações do trabalho (socioprofissionais) se destacam como negativo os aspectos de relacionamento interpessoal (com colegas, funcionários e alunos) dos professores entrevistados $(n=6)$ relataram quanto aos terceirizados (pessoas não tem a qualificação adequada e rotatividade de pessoal), acumular diversas funções, não só é professor e pesquisador, tem que ter características de administrador; insatisfeito no ambiente de trabalho, coletiva; individualismo; pulverização do coletivo; relacionamento entre os colegas e o relacionamento com os alunos é algo muito desgastante; estressantes, de relacionamento interpessoal, lidar com diferenças, podemos observar nas falas abaixo:

P1- "A gente tem servidores terceirizados prestando serviços e, muitas vezes, essas pessoas não tem a qualificação adequada ou, então, não tem o incentivo adequado; a rotatividade de pessoal é muito grande; e faz com que o professor, ele acaba tendo que acumular diversas funções! O professor, ele não só é professor e pesquisador, como também tem que ter características de administrador e fazer trabalho, muitas vezes, dos servidores técnico-administrativos, que por uma razão ou outra, seja pela rotatividade ou falta de interesse...é...não cumprem com as funções de forma desejada!"

P5- "Só existe um probleminha que me deixa um pouquinho insatisfeito no ambiente de trabalho, que entra numa questão que é coletiva, que é não conseguir essa construção coletiva para o objetivo comum. Eu acho que isso aí tá relacionado um pouco à nossa cultura. À cultura no Brasil, à cultura ocidental, que é uma coisa que leva para o individualismo e a gente não consegue construir esse corpo... É essa questão da pulverização do coletivo, essa coisa atomizada de cada um buscando os seus interesses e tal, e a gente não consegue um objetivo maior, um 
bem comum." [...] "Estou dizendo isso porque já me afetou muito mais; hoje já não afeta tanto porque eu fiz um trabalho de reflexão e tal e meio que consegui um processo de superação disso...”.

P6- "[...] o relacionamento entre os colegas e o relacionamento com os alunos é algo muito desgastante em alguns sentidos,... Porque eles discordam um pouco de algumas posições dos outros e ficam achando que os outros deveriam mudar, que não deveriam ser daquele jeito. $\mathrm{E}$ você tem uma relação também difícil, às vezes, com os servidores, que muitas, vezes, estão já numa fase da carreira, assim, que já não tem tanta motivação, e aí, o professor acha que o servidor devia fazer de um jeito e ele não tá fazendo... Já fica insatisfeito, já cria rusga."[...] "Eu não me desgasto tanto com isso, mas vejo que alguns colegas... tem um certo sofrimento com as dificuldades, de você aí fazer esse relacionamento social".

P7- “[...] Existem questões às vezes, estressantes, de relacionamento interpessoal, mas que em ambiente de trabalho, às vezes, a pessoa não é obrigada a lidar com diferenças!.”

P8- “[...] as relações interpessoais de trabalho, porque, de um modo geral, elas não são muito fraternas, elas são... não é uma guerra, mas não são fraternas, sabe?! [...] E, na verdade, também tem muita dificuldade de comunicação, de interação, sobretudo entre professores, mas também entre professores e funcionários...".

P9- "[...] a sobrecarga de trabalho e também as frustrações que a gente tem em relação ao processo de ensino-aprendizagem junto aos alunos. Enfim! É um conjunto de situações que derivam em um trabalho que traz uma pressão!”.

Cabe destacar que os professores, ao relatar as queixas com as relações socioprofissionais, modificavam a entonação da voz e a fisionomia, muitas vezes desviando o olhar para o chão ou para outro lugar, evitando fixar o olhar na entrevistadora.

No entanto, embora em menor frequência, alguns professores apontaram o relacionamento com alunos e colegas como um aspecto neutro ou positivo no contexto de trabalho, como podemos observar a seguir:

P5- "[...] em ao relacionamento interpessoal, eu acho que eu não tenho o que reclamar!"

P6- "[...] tenho um ambiente de trabalho relativamente tranquilo, na medida, com bom entrosamento com os colegas e também familiar!" [...] "Eu acho tranquilo! Mesmo a relação, talvez, de um elemento que é de estresse dentro da profissão do docente, que é o relacionamento com os alunos, eu também, a rigor, já tenho as minhas estratégias de lidar com o estresse e tudo mais...".

Por fim, na subcategoria Condições de Trabalho se destacam os aspectos de estrutura física, conforme podemos observar nas unidades de registro mais frequentes, tais como: 
precariedade das condições de trabalho; falta de internet; dependência tecnológica; falta de ar condicionado; e poluição sonora. Vejamos o uso dos termos nos contextos das falas a seguir:

P4- "Principalmente essa posição que você trabalha; você é muito dependente do computador nesse tipo de atividade! Tem algumas coisas, como a temperatura: dias muito quentes, por exemplo, você não ter um sistema refrigerado, ar condicionado, para temperatura se manter mais agradável para trabalho! E, às vezes, tem a questão, aqui na FEF, de muito barulho! Então, você tem muita poluição sonora...".

P7- "[...] um elemento estressor aqui é a precariedade das condições de trabalho! Então, se está muito quente, eu não tenho uma sala refrigerada e suo enquanto tento pensar na minha pesquisa; é... não tem isolamento acústico, então, na minha sala em cima é vidro, do lado de um corredor onde circula muita gente e então, a todo instante eu estou ouvindo gente - eu não consigo ficar num ambiente quieto". [...] "Pior do que isso é a internet, que é uma vergonha - eu não tenho internet e isso é uma das coisas que me deixa mais furioso! Isso me adoece porque eu planejei trabalhar das duas as seis hoje - quatro horas para escrever um paper e buscar a referência na internet - e aí, eu sento na frente do meu computador e eu não tenho internet para poder fazer as pesquisas que eu preciso! Isso é ruim demais! Já teve vez que eu... eu tenho cooperantes em outros países e, eu marco uma reunião no Skype e tenho que me planejar pra estar em casa e não aqui! Ou, às vezes, começo aqui e tenho que ir pra casa no meio de uma reunião! Isso é péssimo!".

P9- "Então, talvez isso tenha a ver com a necessidade de incremento de novas tecnologias no ambiente de ensino, de muita inovação. A UnB tem dado um certo suporte nisso: a gente busca, mas isso também não é o suficiente! [...] Então isso coloca uma certa frustração..."

Não obstante, alguns professores destacam o ambiente e a estrutura física como aspectos não negativos ou até mesmo positivos no contexto de trabalho, de acordo com as falas abaixo. É interessante notar que a fala de P6 (um professor que ministra disciplinas nas áreas sociais e/ou humanas e tem mais de 11 anos de docência) destoa das demais sendo extremamente positiva quanto às instalações físicas da FEF:

P1- "A estrutura física, ela não é a estrutura ideal, mas, pelo menos para mim nesse momento, ela não me parece causadora de adoecimento. A gente tem salas de aula que não tem totalmente um isolamento acústico, mas como a minha carga de aulas tá dentro de um limite razoável, isso não estressa tanto a minha voz e tudo!”.

P3- “Aqui eu não encontrei lugares que promovem adoecimento... Aqui na FEF também nunca encontrei nenhum professor fumando ou fazendo qualquer coisa que promovesse adoecimento!". 
P6- "[...] tem um bom ambiente de trabalho. Você vê salas iluminadas; um mobiliário novo; tem uma boa ergonomia; a gente, para ajustar alguma coisa... a gente conversa e termina conseguindo! Hoje estamos sem ar condicionado, mas tem um ar condicionado... Para você ver que nós temos uma boa condição de trabalho. Quando você vai para sala de aula, você tem salas de aula que também estão bem equipadas. Você tem ar condicionado nas salas de aula e não tem uma acústica desfavorável, o professor não gasta tanto as cordas vocais...”.

\subsubsection{Percepção dos professores sobre o Apoio Institucional ao Autocuidado}

A partir da perspectiva do local de trabalho identificamos aspectos relacionados ao apoio institucional que os professores percebiam como promotor do autocuidado, conforme indica a Figura 13.

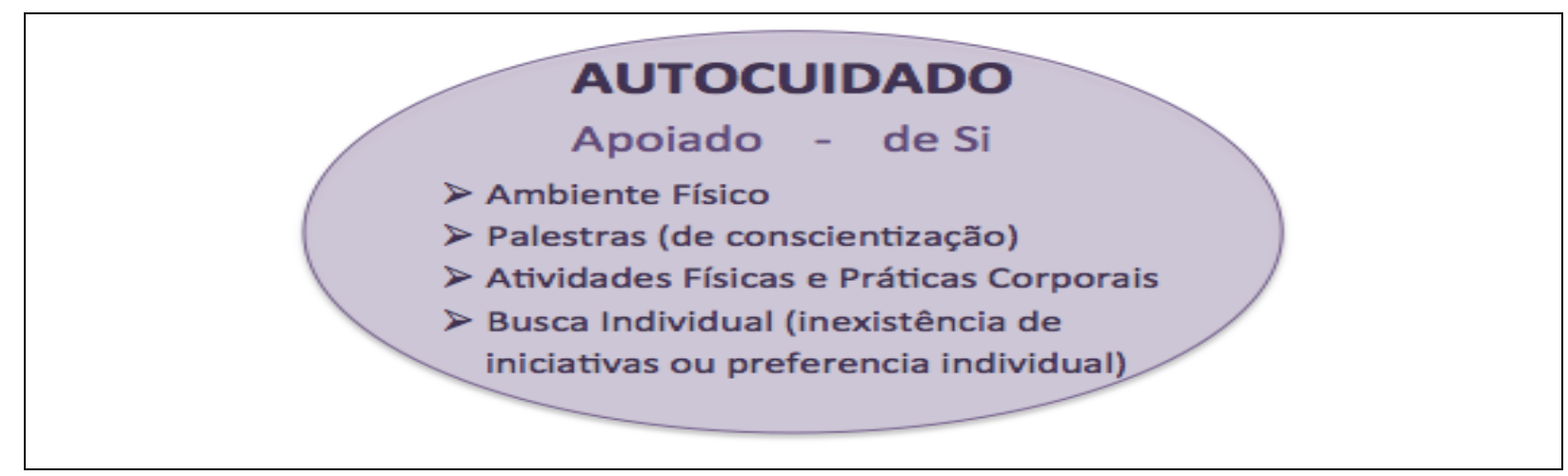

Figura 13. Esquema da Categoria Autocuidado e suas Subcategorias. Fonte: Autora

Quando questionados sobre as possibilidades promotoras de saúde que o ambiente de trabalho na FEF-UnB oferece, todos os professores foram unânimes em apontar o ambiente físico como um aspecto que favorece a prática física, o entrosamento entre colegas e, portanto, promove a saúde e o autocuidado. Alguns termos sobre o ambiente que apareceram nas falas foram: centro olímpico, piscina, campo de futebol, sala de musculação, espaços de práticas corporais, local de encontro com amigos, conforme observamos nas falas a seguir:

P5- "[...] eu jogo com os amigos aqui [na FEF], eu jogo basquete com os amigos, que tem o cunho lúdico; não é de resultado! Eu entrei num grupo, num projeto que trabalha com ... que é uma modalidade bem interessante, que é focada na competição interna, que o lúdico é o principal, e não o resultado, e tem regras próprias!”.

P6-“A FEF, e aqui particularmente nós estamos no Centro Olímpico, então, para mim, a piscina está a minha disposição; o campo de futebol está a minha disposição; a sala de musculação está a minha disposição; eu posso usar todos esses equipamentos na hora em que eu quiser, sem nenhuma dificuldade! Então, a FEF está numa situação diferente [do resto da UnB].”. 
P8-“A FEF oferece ao professor a oportunidade de usar os espaços aqui como a academia, as salas pra fazer práticas corporais, a piscina, o Centro Olímpico; um espaço que fica sempre aberto e oferece a oportunidade de caminhada, corrida".

P9- “[...] o ambiente da UnB, por ser uma Faculdade de Educação Física, te coloca em contato com as práticas corporais e isso acaba te estimulando, se não aqui, em outros espaços. [...] Aqui a gente tem esse Centro Olímpico que é bem legal, tem muito verde, tem um lago [...] pe posso fazer as minhas atividades diárias!".

Foi interessante notar que, ao destacar esses aspectos, as expressões faciais se alteravam de forma positiva refletindo um aspecto de encantamento em trabalhar no ambiente da FEF-UnB.

Além do ambiente físico os professores relataram como sendo um espaço promotor de autocuidado e saúde, emergiram ainda que de forma esporádica as seguintes unidades de registro: palestras de conscientização e atividades físicas e práticas corporais, conforme podemos observar nas falas:

P3- "Existem hum [...] São palestras de conscientização para promoção da saúde... Palestras e atividades. Mas tem que ter um programa!." [...] "Então, e tinha o futebol de salão pros funcionários! Já teve aula da academia - de meio dia às duas... - não tinha uma adesão grande nem de professores e nem de funcionários!”

P4- "Tem uma associação dos professores da UnB que agora tá oferecendo algumas atividades, como pilates, xadrez, me parece! Mas, fora isso, eu acho que não há muitos programas nem atividades...”.

P8- “[...] se a Universidade oferecesse alguma prática, não dessas tradicionais que a Educação Física tradicionalmente explora, voltadas para aptidão física, mas se tivesse um grupo de biodança, por exemplo... é... de tai chi chuan, de yoga... Dependendo das minhas condições... isso me estimularia mais do que essas práticas físicas tradicionais [que são oferecidas]".

Em contraponto, é importante destacar que alguns professores não identificaram nenhuma iniciativa de apoio institucional relacionada à promoção do autocuidado e da saúde, conforme vemos nas falas a seguir:

P2-“[...] não, nenhum questionário sobre isso [as necessidades em saúde do professor]! Não oferece atividades...”.

P4- “[...] não tem muita iniciativa em relação a isso: campanhas ou material informativo... Nada disso! [...] Eu acho que não há muitos programas nem atividades, nem para professores...”. 
P5- "[...] Ela [a universidade] tem um potencial enorme para essa questão de trabalhar a qualidade de vida... mas ela poderia ter esse potencial aumentado! Eu acho que ela não é proativa nesse sentido! Ela deixa muito por conta da busca individual: cada um buscando! Não existe um programa que favoreça isso! Então, por isso que eu acho que ela deixa a desejar nesse sentido!".

Interessante destacar ainda que alguns professores afirmaram que, por preferência individual, optam por não utilizar os serviços de apoio oferecidos pela instituição. Vejamos as falas:

P1- "Opto por não praticar aqui na UnB justamente para ser um momento onde eu consiga estar fora do ambiente de trabalho!...você sempre encontra ou um colega ou um aluno, enfim! Então, acaba mantendo aquela sensação de ambiente de trabalho!".

P2- “Então, eu não uso os serviços da instituição, porque eu não quero mesmo [...] Agora, é aquilo que eu falei: mesmo que oferecesse... eu prefiro fazer por conta própria! A minha atividade física no lugar que eu quero, na hora em que eu quero... com a família!”

\subsubsection{Percepção dos professores sobre a Prática do Cuidar de Si}

Além das práticas corporais e atividades físicas que já emergiram nas falas relatadas anteriormente, buscamos informações adicionais para saber o que o professor fazia para cuidar de si e de sua saúde. Foram relatados aspectos e práticas: físicas (alimentação, exercício), mentais (estudo, sono), espirituais (meditação, autoconhecimento); e emocionais (psíquico, prazer, lazer, família). Vamos aos termos nos contextos das falas:

P1- "Eu busco controlar esse estresse, essa ansiedade através de atividades físicas regulares! Eu pratico musculação e natação. Às vezes, uma corridinha... se eu não posso manter a atividade regular, chego no final da semana mais cansada, mais estressada... tem um benefício claro em termos da saúde, tanto física quanto metal!.”

P2- “...eu fazia musculação, mas cansei um pouco de academia... De ambiente fechado. Agora eu prefiro caminhar no parque ou alguma coisa assim! Me dá vontade de fazer o que me dá prazer, o que tá me dando satisfação naquele momento! [...] Se tem elevador, eu não uso! Eu prefiro subir de escada... Moro no quarto andar. Só subo escada.".

P3- "Eu faço exercícios físicos e... para promover eu estudo... Então, eu sei... o meu trabalho até ajudou a promover a minha saúde... saber que exercícios físicos ajudam a promover a saúde; bons hábitos alimentares.” [...] É, eu faço por prazer; eu faço porque eu gosto e porque eu sei que é importante!" 
P4-“Eu faço atividade física e não tenho muitos problemas de saúde!... É... alimentação, sono, horas de lazer... é basicamente isso! [...] E no próprio trabalho, fazer coisas que tragam algum tipo de satisfação e prazer!...”.

P5- "Então, eu estou atualmente fazendo quatro modalidades de artes marciais! E, assim, é com muito prazer que eu faço isso tudo! São as principais atividades que eu faço!" [...] "Dentro de algo que você gosta de fazer tem os momentos de sacrifício e você tem que fazer! Mas, grande parte do que eu faço tá dentro de uma vontade intrínseca. Não é extrínseca! É intrínseca! É o que eu quero fazer! Eu acho que esse é um aspecto muito importante... para essa minha qualidade de vida!".

P7-“... procuro fazer atividade física regularmente, mas não tenho conseguido! Então, acaba sendo uma frequência bem inferior à que eu gostaria! ... Então, quando dá, eu corro! Quando dá, eu faço um pouco de musculação! Quando dá, eu jogo basquete! Quando dá, eu nado!... É um hábito arraigado, assim, desde que eu sou muito pequeno, que eu pratico esporte, atividade física! O meu corpo pede demais por isso!".

P8- “ Não estou fazendo uma atividade física regular agora; nos dois últimos meses eu estou meio parado, mas eu faço duas ou três vezes por semana alguma atividade. [...] Tem minha prática espiritual, por exemplo, a meditação como uma atividade que precisaria ter mais disciplina. Mas, ainda assim, é algo que está muito presente! A própria terapia que eu faço para cuidar da minha saúde mental, da minha saúde psíquica! Oro, medito, procuro estar em contato com a natureza também!" [...] "Eu tenho procurado cuidar da minha alimentação... e trabalho em termos de organização de tempo, de espaço, favorece que eu possa cuidar da minha saúde, me dá tempo para cuidar da minha saúde..." [...] "Vivo constantemente esse processo de autoconhecimento pra quem sabe, um dia, me tornar uma pessoa verdadeiramente saudável psiquicamente."

Podemos notar que as práticas corporais e atividades físicas dominam os discursos dos professores, embora alguns denotem haver dificuldade para a realização regular e contínua destas práticas.

\subsubsection{Percepção dos professores sobre a promoção da saúde.}

Para finalizar, apresentamos as concepções de Promoção da Saúde que emergiram com as análises das entrevistas. No geral, algumas falas $(n=2)$ expressam uma visão mais ampliada ou integral da saúde, o que reflete também na concepção ampliada de promoção da saúde, incluindo termos como: bem estar, prazer, educação, trabalho, cultura de paz, ambiente (natureza), coletividade, determinantes do ritmo de vida, prática corporal, cuidado de si, e produção criativa da vida. 
P8- "Me coloco o tempo todo numa reflexão sobre a sobre a minha condição de saúde. O meu bem estar! Me faz também levar para pessoas, um conhecimento que tá diretamente relacionado à Educação e à Saúde, porque para mim, você só tem saúde quando você se educa ou é educado, no sentido do processo de aprendizado.[...]A gente vive num hospital a céu aberto... para um dia virar uma escola a céu aberto, até que todo mundo se torne são, saudável integralmente e feliz, e o mundo em paz! Então, a saúde, no meu entender, vai longe. Ah!”. [...] "Mas eu cuido pra isso: eu tenho uma vida saudável, no sentido bem amplo da palavra "saúde" ou "saudável"... para me sentir bem e em condições de trabalhar, porque quem chega nesse planeta aqui é pra trabalhar...".

P9- "O envelhecimento é uma realidade! Então, eu acho que a gente tem que ter cuidado em viver bem. E isso envolve uma prática corporal. Agora, fazer algo que também lhe dê prazer. [...] Então, eu vou variando um conjunto de atividades que me dão prazer, sem abandonar o futebol, que é um espaço para além da prática corporal: me confere uma identidade de grupo, um coletivo, um espaço de sociabilidade." [...] "A prática corporal é algo fundamental para gente! O cuidado de si, o cuidado com o corpo não numa paranoia, em função do embelezamento corporal [...] mas em outros espaços de prática! Procuro estar em contato com a natureza também! Sair, da cidade ou mesmo estando aqui [na UnB], a gente tem esse Centro Olímpico que é bem legal, tem muito verde, tem um lago" [...] "Então, eu acho que a saúde de todo e qualquer professor hoje, ela vem sofrendo um pouco, em função desse processo de aceleração dos ritmos diários da vida em função de sobrecarga de trabalho. É um conjunto de situações que derivam em um trabalho que trazem uma pressão! "Eu acho que compromete o que eu chamei de produção criativa da vida...”.

Não obstante, alguns professores $(n=3)$ deram destaque à aspectos como: práticas e comportamentos individuais, e benefícios biológicos, de certa forma, um fenômeno reducionista demonstra que apesar dos avanços na área da saúde, persiste, em alguns casos, a concepção reducionista e linear no discurso de profissionais. Este enfoque é evidenciado por meio de ações pontuais, assistencialistas e curativistas de promover e intervir no binômio saúde-doença. Vejamos algumas falas a seguir:

P4- " $\mathrm{Eu}$ tento manter uma regularidade atividade física tanto durante a semana como no final de semana para manter a saúde, para meu bem estar, para ter prazer também!".

P5- "[...] se há um ponto que possa determinar isso [a falta de saúde] é essa questão da pulverização do coletivo... essa coisa atomizada de cada um buscando os seus interesses e tal, a gente não conseguir um objetivo maior, um bem comum! Isso seria um ponto, a meu ver, predisponente a essa falta de saúde".

P6-"A gente sempre - fazendo uma avaliação crítica - percebe que tem alguns cuidados adicionais que a gente precisaria está tomando. Hoje em dia, eu acredito 
que eu tenho uma boa alimentação, umas boas horas de descanso, mas eu ainda fico insatisfeito com a quantidade de atividade física que eu consigo fazer! [...] já tenho as minhas estratégias, de lidar com o stress e tudo mais".

É importante destacar que não as falas dos professores não expressam uma dualidade de percepções sobre o conceito de promoção da saúde mas sim, se aproximam de um mosaico onde diversas percepções se complementam ou as vezes se antagonizam mas sempre se interconectam na tentativa de descrever os processos relativos à produção da saúde (Figura 14).



Figura 14. Esquema de interconexões das percepções sobre Promoção da Saúde. Fonte: Autora 


\section{DISCUSSÃO}

Uma impressão geral sobre as entrevistas indica a necessidade de um olhar abrangente no qual a compreensão dos processos de saúde e adoecimento é obtida tomando como base a dinâmica social que constitui o trabalho e as relações entre condições, ambientes e sujeitos. Assinala também o reconhecimento de que diversos elementos do sujeito e do ambiente, tais como a trajetória individual do docente e as relações sociais, os aspectos organizacionais e os ambientes de trabalho podem ser agentes promotores de saúde. Identifica também que os docentes do curso de Educação Física da FEF/UnB reconhecem o contexto de trabalho como fator que afeta sua saúde, e que aspectos ambientais do local estavam fortemente atrelados ao apoio das práticas corporais como cuidado de si.

Serão relacionadas a seguir as discussões que possibilitaram verificar interseções entre a percepção dos professores da FEF/UnB sobre a promoção de saúde e a relação entre saúde e trabalho; a percepção do contexto de trabalho dos docentes da FEF/UnB e os determinantes sociais da saúde; o aprofundamento no tema e a situação de saúde no contexto de trabalho; a percepção dos professores sobre o apoio institucional e o autocuidado apoiado; as relações entre a saúde e o prazer e sofrimento no contexto de trabalho; e a UnB e a FEF, promotoras (ou não) da saúde.

\section{Percepção dos professores da FEF/UnB sobre a promoção de saúde e a relação entre saúde e trabalho}

O conceito moderno de promoção da saúde (e, consequentemente, da prática) vem se destacando de forma vigorosa nos últimos 20 anos (BUSS, 2000), sendo compreendido com base na complexidade que envolve a preservação dos potenciais de saúde de indivíduos e grupos sociais de forma articulada às demais políticas e tecnologias de intervenção social (BRASIL, 2014). Considera-se a abordagem alinhada à concepção moderna de promoção da saúde na qual os professores identificaram a determinação social dos processos de saúde e doença com o contexto de trabalho e o autocuidado (apoiado e de si). Isso fica evidente quando os professores da FEF acenam para promoção da saúde, prazer, educação, trabalho, cultura de paz, ambiente (natureza) e coletividade, como determinantes do ritmo de vida, prática corporal, cuidado de si, e produção criativa da vida (Figura 14). Outros autores também identificam concepções ampliadas de promoção da saúde quando chamam atenção para a promoção da saúde, a integralidade, a singularidade, a humanização, a 
multidisciplinaridade, a interdisciplinaridade e o completo bem-estar, considerando, também, a importância do diálogo, da escuta, do carinho, do amor e da qualidade de vida (DALMOLIN et al., 2011). Igualmente quando definem promoção da saúde como estratégia de produção social de saúde que apresenta um modo de pensar e de operar relativo à potencialização das capacidades individuais, coletivas e das comunidades em relação aos inúmeros condicionantes envolvidos nos processos saúde-doença-cuidado, reconhecendo o sujeito empoderado como agente transformador da realidade (BACKES et al., 2009).

No entanto, alguns professores demonstraram ter uma visão centrada nos aspectos individuais e biomédicos de promoção da saúde e não identificam em suas falas aspectos adoecedores no contexto de trabalho, muito embora os tenham mencionado nos questionários (Escala de Avaliação do Contexto de Trabalho e o Cartão de pontuação do apoio à saúde no local de trabalho). É bastante provável que essa concepção oriente seus discursos e práticas em saúde (SANTOS et al., 2006), inclusive em relação à formação dos futuros profissionais de Educação Física - aspecto que necessita de maior aprofundamento em futuras pesquisas. É importante destacar que se trata de uma concepção reduzida que, hegemonicamente, embasa os discursos técnico-científicos e as práticas da Educação Física na grande área da saúde nas últimas décadas (CECCIM; BILIBI, 2007), estando mais afinada aos saberes biomédicos com enfoque na prevenção de doenças crônicas e na recuperação terapêutica (LUZ, 2007). Entretanto, não se trata de negar as perspectivas biológicas, mas de reconhecer que essa visão, isoladamente, é incapaz de explicar o fenômeno saúde no contexto contemporâneo (ASSUMPÇÃO; MORAIS; FOUTOURA, 2002).

Para tanto, alguns outros professores relacionam a concepção de promoção da saúde com os discursos e as práticas a partir de dois olhares, o ampliado e o reduzido, os quais, em alguns momentos se interligam, se complementam e se confundem. São capazes de identificar as relações entre condições, ambientes e sujeitos, porém justificam e realizam suas práticas corporais de formas pontuais, isoladas, e como comportamentos individuais destinados a obter benefícios biofisiológicos.

Reconhecendo o docente de Educação Física (em especial o universitário) como um agente de promoção da saúde (SCHMITT, et al., 2015), um agente de transformação que deve vivenciar e contribuir com a criação, difusão e implementação de estratégias promotoras de saúde no ambiente de trabalho ou fora dele, defende-se aqui que este deve compreender a promoção da saúde como uma estratégia que ultrapassa os cuidados pessoais com a saúde, muito além das abordagens técnicas de saúde, e que contempla a articulação com outras 
esferas e tecnologias de intervenção social visando construir espaços e ações que respondam às necessidades sociais em saúde (BRASIL, 2006; BUSS, 2000).É preciso repensar “o ser" e "o fazer" do docente de educação em saúde, a fim de atender aos princípios vigentes de promoção da saúde, bem como de suscitar novos referenciais capazes de repensar a saúde muito além da dimensão biológica e fisiológica (focada na doença), objetiva (atividades pontuais) e individual (comportamental). As IES precisam superar a ideia assistencialista de saúde no trabalho, o que implica abarcar a integralidade do cuidado e do autocuidado, além da perspectiva do docente como um ser integral e complexo (DALMOLIN et al., 2011).

Pensar sobre a saúde dos docentes da área da saúde é repensar o modelo de trabalho e de formação nas IES de forma a ampliar as possibilidades interativas - além da articulação teoria e prática - por meio de debates e discussões que fortaleçam e divulguem o conceito de saúde segundo uma perspectiva ampliada (DALMOLIN et al., 2011).

Por sua vez, este trabalho parte do entendimento de que a saúde é um fenômeno complexo determinado por ampla rede de relações (BUSS; FILHO, 2007) na qual vários fatores em sinergia determinarão o estado de saúde do indivíduo e da coletividade, segundo os referenciais teóricos da promoção da saúde (CAMPOS, 2006). Ademais, empreendeu-se uma análise crítica sobre a situação de saúde de professores da FEF/UnB, fundamentada nos condicionantes e determinantes relacionados ao trabalho.

$\mathrm{Na}$ presente pesquisa, quase a totalidade dos professores da FEF/UnB entrevistados relataram alguns aspectos negativos de sua saúde. Isso fica mais evidente quando se relaciona saúde e trabalho, com destaque para o ritmo de trabalho excessivo, tarefas administrativas desgastantes, metas de produtividade, entrosamento e relacionamentos sociais, e a precarização das condições de trabalho. Resultados e conclusões das publicações sobre a saúde dos professores universitários (recorte área de saúde), quando relacionados saúde e trabalho, identificaram fatores negativos à saúde que permitem ampliar o grau de compreensão acerca dos riscos e evidências de processos de adoecimento, em especial nas dimensões físicas e psicológicas relacionados às condições de trabalho no ambiente universitário (LEMOS, 2005; LIMA; FILHO, 2009).

Observa-se assim que evidências da percepção de docentes universitários da FEF/UnB sobre os processos de saúde e adoecimento no trabalho apontam que as esferas pessoais, sociais e institucionais devem atuar conjuntamente a fim de atender às complexas necessidades contemporâneas em saúde. Por sua vez, os aspectos produtores de adoecimento em seu ambiente de trabalho estão relacionados com a estrutura da organização 
(COUTINHO; MAGRO; BUDDE, 2011; SILVA et al., 2016); estilo de vida (BOTH; NASCIMENTO; BORGATTO, 2008); estrutura física (GARCIA; OLIVEIRA; MAURO et al., 2008); pulverização do coletivo, problemas de relacionamento social (LAGO; CUNHA; BORGES, 2015; ULRICH, 2005), e com as metas de produtividade (FONTANA; PINHEIRO, 2010).

Para que haja um ambiente de trabalho saudável dentro da universidade é necessário considerar a promoção da saúde como seu eixo principal, tendo como objetivo melhorar o estilo de vida dos indivíduos numa visão de desenvolvimento integral, capacitando-os para a extrapolação dos comportamentos adquiridos nos diferentes contextos em que se movem e no seu futuro como cidadãos (SILVA; BRITO, 2014).

Não obstante, a associação com os aspectos positivos à saúde e ao trabalho estão relacionados à satisfação profissional decorrente da produção de conhecimento e do impacto social que suas atividades laboriais (DALLACOSTA, 2014; FERREIRA, 2011; GARCIA; OLIVEIRA; MAURO, 2008; GONÇALVES; PIRES, 2015; MARQUEZE; MORENO, 2009; TREVISO, 2015) promovem e podem contribuir para a implementação de estratégias promotoras de saúde no ambiente de trabalho. Chama atenção na pesquisa o fato de os aspectos de satisfação com o trabalho e saúde estarem associados ao relacionamento interpessoal e motivação, condições e organização de trabalho.

Concordando que diversos elementos - sejam os individuais ou os sociais - afetam diretamente a concepção e as ações em promoção da saúde, serão abordados a seguir, mais profundamente, cada um desses aspectos.

\section{Percepção do contexto de trabalho dos docentes da FEF/UnB e os determinantes sociais da saúde}

Ao se observar o contexto de trabalho e a percepção sobre a situação de saúde dos professores da FEF/UnB, é possível constatar que alguns professores das áreas sociais e humanas tendem a uma percepção negativa das dimensões organização, relações e condições de trabalho. Isso ocorre apesar de os resultados, em termos da especificidade da amostra investigada, envolverem uma maioria de homens, de meia idade, brancos, com abordagens eminentemente biológicas ou técnicas em suas disciplinas e que ingressaram recentemente em IES.

Segundo o Instituto Nacional de Estudos e Pesquisas Educacionais Anísio Teixeira (INEP, 2015), os homens ainda representam maioria ( 55\%) dos docentes que atuam nas IES, 
a despeito de alguns cursos da saúde serem hegemonicamente femininos, tais como nutrição e enfermagem, e de um aumento substancial na proporção feminina no mercado de trabalho nos últimos anos (OLIVEIRA; GARCIA; GOMES et al., 2012; ROCHA; SARRIERA, 2006). Não obstante, merece destaque a maior participação de mulheres - proporcionalmente - no presente estudo. Não é possível assegurar, mas essa maior participação, mesmo diante de um contexto de excesso de trabalho, pode apresentar relação com a propensão feminina à melhor adaptação a multifunções profissionais e/ou familiares (LUDERMIR, 2000; OLIVEIRA; GARCIA; GOMES, 2012). Pesquisas futuras podem avançar na compreensão sobre o acúmulo de atividades a que geralmente as mulheres se submetem, refletindo-se no aumento dos níveis de estresse e outros problemas psicossomáticos que comprometem a qualidade de vida dessas trabalhadoras (CHRISTOPHORO; WAIDMAN, 2002; SOUZA et al., 2015).

Outra característica interessante é que quase metade dos professores da FEF entraram numa IES nos últimos dez anos, e muitos já atuam na pós-graduação, indicando que políticas federais recentes - como o Programa de Reestruturação e Expansão das Universidades Federais (REUNI) e o Plano Nacional de Pós-Graduação (2011-2020) da Coordenação de Aperfeiçoamento de Pessoal de Nível Superior (CAPES, 2016) - contribuíram para a expansão e ampliação do acesso à educação superior e à pesquisa no Brasil (BRASIL, 2003). No entanto, foi marcante constatar a maior participação no estudo dos professores com maior tempo de docência nas IES, sendo que metade da população jamais havia atuado em de cargos administrativos. Além disso, aspectos de motivação (intrínseca e extrínseca) também precisam ser mais bem compreendidos por futuras pesquisas (ZANELLI; BORGES; BASTOS, 2004). Há indícios de que a valorização da lógica produtivista centrada na produção científica leve os docentes a priorizar essas atividades em detrimento de outras demandas no contexto do trabalho (FONTANA; PINHEIRO, 2010; MANCEBO; SILVA Jr., 2012).

Por fim, reconhecem-se aspectos da esfera pessoal como vivências e formação em saúde, com leve predominância das disciplinas biológicas e/ou técnicas na amostra de docentes e na população da FEF, o que se acredita influenciar as práticas docentes e as perspectivas adotadas. As vivências pessoais e sociais são entendidas como produtos e produtoras do ambiente, das normas, da gestão e da organização do trabalho (aspectos institucionais) (DEJOURS, 1987). Podem ou não ser ressignificadas pelos sujeitos (COUTINHO; MAGRO; BUDDE, 2011). No caso do presente estudo, serão ressaltados a 
seguir dois aspectos relativos ao docente da $\mathrm{FEF} / \mathrm{UnB}$ que podem afetar diretamente a saúde: os determinantes sociais da saúde e o contexto de trabalho nas esferas sociais e institucionais.

Dialogando com os referenciais teóricos dos determinantes sociais e condicionantes da saúde (BUSS; FILHO, 2007), será dado continuidade ao aprofundamento na análise das condições objetivas e subjetivas do contexto de trabalho, as quais podem estar envolvidas nos processos de saúde e adoecimento nas esferas social e institucional. As IES precisam superar a ideia assistencialista de saúde no trabalho, o que implica abarcar a integralidade do cuidado e do autocuidado, e adotar a perspectiva do docente como um ser integral e complexo (DALMOLIN, et al., 2011), inserido em um contexto de trabalho contraditório (CHICKERING; GAMSO N, 1987).

Ao se compatibilizar os determinantes sociais de saúde com um modelo mais abrangente do fenômeno saúde/doença, é impossível negar a existência e/ou relevância do fenômeno biológico, muito menos do processo de interação estabelecido entre o agente causador da doença, o indivíduo suscetível e o ambiente (BRASIL, 2006; 2006a). Entretanto, destaca-se o papel do contexto no processo do trabalho, incluindo as possibilidades promotoras de saúde que a universidade oferece ou não. Nessa perspectiva, podem-se identificar três subcategorias e/ou dimensões que emergem da literatura, assim como a percepção dos professores da FEF quanto à organização, as relações e as condições de trabalho.

A percepção dos professores quanto ao contexto de trabalho levanta reflexões sobre melhores práticas para promoção de bem-estar nesse ambiente, bem como traz ponderações sobre eficiência e eficácia dos processos organizacionais. Nesta pesquisa alguns desses aspectos apresentaram diferenças quanto às variáveis: anos de docência, disciplinas ministradas na FEF, e atuação na pós-graduação. O novo perfil epistemológico requer um enfoque complexo e integral, voltado para o ambiente salutogênico promotor de autocuidado, demandando ações que incorporem no cotidiano social, do indivíduo e da assistência, princípios formativos e educativos em saúde (ROCHA; CENTURIÃO, 2007).

Ainda sobre o contexto do trabalho, a pontuação média obtida indica uma situaçãolimite potencializadora de mal-estar e, com isso, promotora de risco de adoecimento. É sinalizado então um estado de alerta que exige providências a curto e a médio prazo (FACAS, 2013; MENDES, 2007), principalmente nos aspectos da estrutura organizacional (terceirização, rotatividade e baixa qualidade de pessoal) e produtivismo (pressão e ritmo das atividades). O mesmo se verifica em relação aos relacionamentos pessoais (consigo mesmo, e 
com colegas, funcionários e alunos), pois as ações devem estar focadas nas causas para eliminar e atenuar o mal-estar no ambiente de trabalho (MENDES, 2007).

Observa-se assim que as intervenções em saúde devem ampliar o escopo, tomando como objeto os problemas e necessidades de saúde e os determinantes e condicionantes de saúde (BRASIL, 2006). O comportamento do professor é avaliado no contexto onde ele está inserido. De modo geral, é possível considerar que o seu comportamento e as relações que estabelece com os colegas e seus alunos ocorrem dentro de um contexto organizacional que as influencia (ULRICH, 2005).

Nessa perspectiva, ressalta-se a dimensão relações socioprofissionais. Os achados apontam um forte risco de adoecimento e possibilidade de produção de mal-estar no trabalho, tanto no questionário (escala de avaliação do contexto de trabalho) como nas entrevistas. As condições ambientais, culturais e econômicas influenciam diretamente a qualidade de vida e a saúde da comunidade e seus membros (BUSS, 2000). O excesso de tarefas e responsabilidades advindas da atuação no tripé universitário (ensino, pesquisa e extensão) e ainda as atividades administrativas e financeiras que se acumulam na sua carga de atividades têm levado alguns docentes a apresentar dificuldades em cumprir as exigências (MELLO; MOYSÉS; MOYSÉS, 2009) e, ao mesmo tempo, afetam a sua saúde (nas esferas física e emocional) - a saúde no sentido amplo enfatiza os recursos sociais e pessoais bem como a capacidade física (OMS, 1986).

A saúde no trabalho está presente na busca dos trabalhadores, em sua organização de trabalho, pela integridade física, psíquica e social e se viabiliza pelo uso eficaz de estratégias de mediação para responder às diversidades do contexto de produção, possibilitando a ressignificação ou transformação do sofrimento no trabalho. (FACAS; MACHADO; MENDES, 2012; FERREIRA; MENDES, 2008; MENDES, 2007a; FERREIRA; MENDES, 2003). Assim, será abordada a seguir a situação de saúde no sentido amplo, contemplando mais de um indicador relacionado ao contexto de trabalho.

\section{Aprofundamento no tema situação de saúde no contexto de trabalho}

Percebe-se que as mudanças tecnológicas tanto proporcionam aos profissionais imediatismo resolutivo e atualizações constantes, quanto deles demandam esse mesmo imediatismo e atualizações, afetando o ritmo e a capacidade de assimilar tarefas (BAUMAN, 2001). A ampliação do uso dessas tecnologias informacionais e de comunicação no contexto 
de trabalho acaba por favorecer o aumento de novas tarefas no cotidiano docente e prolonga o tempo de trabalho (COUTINHO; MAGRO; BUDDE, 2011).

Não obstante, diversos outros estudos afirmam que a crescente crise (do sistema educacional e nas instituições de ensino), assim como as divergências e o descaso com a educação no cenário nacional têm reflexos nas condições de trabalho dos docentes (CODO, 1999; ESTEVE, 1999; TENFEN, 1992; WENZEL, 1991). Vivências subjetivas de desgaste físico e emocional acumuladas no trabalho se traduzem, com o passar do tempo, em sentimentos depressivos e em fadiga crônica, compondo um estado anímico denominado Síndrome do Esgotamento Profissional (SANTINI; NETO, 2005).

Outro estudo de Silva e Silva Jr. (2010) conclui que a assunção e a naturalização do produtivismo acadêmico tende a se colocar acima das convicções pessoais, interferindo nas relações de trabalho e na própria subjetividade. O docente se encontra sozinho sem os apoios sociais necessários, com pouco apoio institucional e mergulhado em um universo de demandas e exigências, intensificando um sentido negativo do processo de trabalho (MARTÍNEZ; VALLES; KOHEN, 1997).

Os achados assinalaram alguns aspectos negativos em relação à dimensão/subcategoria organização de trabalho. Entre eles, o ritmo de atividades administrativas, a estrutura organizacional, o sucateamento da universidade, a falta de qualificação dos funcionários administrativos, a rotatividade, a dificuldade em cumprir as metas de produtividade e o processo de avaliação para progressão na carreira. No entanto, segundo Servilha e Arbach (2011), as respostas dos professores aos aspectos negativos - no que concerne aos riscos ocupacionais ligados à organização do trabalho - ocorrem em ordem decrescente: ritmo de trabalho estressante, levar trabalho para casa - ambos com presença de estresse -, e interferência dos fatores do ambiente de trabalho na vida pessoal ou na saúde.

De fato, o esgotamento do professor se torna evidente no cansaço geral, indisposição, ansiedade e na dificuldade para dormir. De maneira geral, o que se percebe é acúmulo e sobrecarga de trabalho (OLIVEIRA; FREITAS, 2008). As tarefas tendem a ser diversificadas, porém fragmentadas; aumentam as exigências profissionais por qualificação e metas de produtividade nas publicações, orientações e participação na comunidade científica. Vale mencionar que as transformações recentes nas esferas política, econômica, cultural e tecnológica vêm afetando profundamente as formas de organização e o cotidiano do trabalho no sistema educacional (FONTANA; PINHEIRO, 2010). 
É interessante notar que os aspectos positivos na organização do trabalho estão vinculados à flexibilidade de horário e à facilidade de organização do tempo. É nesse sentido que alguns estudos se destacam ao defender que os docentes universitários são capazes de, ao enfrentar alguns desses obstáculos, mobilizar os recursos disponíveis na busca de soluções criativas e colaborativas de forma a tornar o trabalho possível e ainda, obter resultados positivos no exercício da profissão (BUDDE, 2011; COUTINHO; MAGRO; SANTOS, 2006; SILVÉRIO et al., 2010; ULRICH, 2005). Percebemos que o professor da FEF-UnB busca alternativas para tornar o trabalho mais agradável, e assim obtém resultados positivos no exercício de sua profissão.

Com base na pesquisa realizada, foi possível constatar como as mudanças no contexto universitário, discutidas anteriormente, vêm afetando o cotidiano de trabalho dos docentes entrevistados - e a saúde dos professores universitários implica a análise dos modelos de gestão implementados IES (MELLO; MOYSÉS; MOYSÉS, 2009).

A quantidade excessiva de atividades profissionais, extrapolando a carga horária formal, é apontada como fator de sofrimento, pois o trabalho invade e determina os outros momentos da vida. Até mesmo as horas que deveriam ser destinadas ao lazer acabam sendo ocupadas com atividades referentes à docência (COUTINHO; MAGRO; BUDDE, 2011). Outros estudos, como os de Gomes (2002) e Oliveira (2001), levantam dados em que os professores fazem referência à sobrecarga em seu trabalho e mencionam a invasão do espaço e do tempo pessoal pelo trabalho. E ao serem indagados a respeito das organizações e dos indivíduos, da criação de ambientes, oportunidades e escolhas saudáveis, as respostas do apoio institucional estão relacionadas com as intervenções e ações dentro e fora da IES.

\section{Percepção dos professores sobre o apoio institucional e o autocuidado apoiado}

Para a implementação e desenvolvimento de comportamento de autocuidado dentro da IES é necessário disponibilização e acessibilidade aos cuidados de saúde e a outros equipamentos sociais (SILVA; BRITO, 2014). Sabe-se que a saúde é um campo de investigação ou objeto de estudo de natureza imprecisa e não linear, exigindo uma complexidade de diálogo entre áreas e subáreas (CARVALHO, 2005).

Na maioria das situações, o desafio dos docentes dentro da IES é potencializar os espaços de interação com os participantes dos processos de ensino-aprendizagem visando à promoção de um ambiente coletivo saudável, mesmo em situações de conflitos, e ao mesmo tempo desenvolver estratégias de autocuidado (SILVÉRIO et al., 2010). 
Nesse sentido, o apoio ao autocuidado institucional é validado e construído com base em evidências científicas de modo que possam constituir um arcabouço de estratégias, de suporte social e de informações (MENDES, 2012), pois, segundo a pesquisa, são poucas as iniciativas oferecidas para os docentes da UnB. Os professores da FEF, por sua vez, trazem ponderações e apontamentos favoráveis ao ambiente físico para a prática corporal e a atividade física, o entrosamento entre colegas e, portanto, promove a saúde e traz qualidade de vida, além de espaços de interação social com vistas à promoção de um ambiente coletivo saudável.

Na perspectiva do ambiente físico e organizacional, segundo o estudo de Silvério et al. (2010) observa-se que o trabalho docente e a qualidade de vida mantêm conexão entre si e esta é positiva quando o ambiente organizacional e as relações entre docentes, alunos, população e coordenação de curso são equilibradas - a mesma percepção é evidenciada quanto ao espaço promotores de autocuidado e saúde da FEF.

Contrapondo-se a essa ideia, três professores da instituição identificaram ausência de iniciativas de apoio institucional relacionada à promoção do autocuidado e da saúde. Os indivíduos buscam, por conta própria, a promoção da saúde e a prevenção das doenças (DIÓGENES; PAGLIUCA, 2003).

Diante dos aspectos apontados, percebe-se a necessidade de se compreender as relações mais amplas entre os determinantes ambientais da instituição que influenciam as relações dentro e fora do ambiente de trabalho, e outros determinantes sociais do processo, tanto mais amplos (como política, economia e cultura), quanto mais individuais (a família, o indivíduo e suas subjetividades) (LAGO; CUNHA; BORGES, 2015). Paralelamente, cabe à gestão universitária criar políticas que favoreçam tais espaços e promovam a ampliação do diálogo com os docentes objetivando o desenvolvimento de ações capazes de melhorar a qualidade de vida no ambiente universitário (SILVÉRIO et al., 2010).

A observação do ambiente universitário revela a necessidade de, em pesquisas futuras, a realização de investimento, além de aprofundamento em apoio institucional ao autocuidado da UnB, de maneira que os professores convivam com suas condições de saúde e se mantenham ativos, com qualidade de vida e bem-estar no desempenho de seus papéis sociais (MENDES, 2012).

Não obstante, o autocuidado apoiado promove o cuidado de si e gera condições que favorecem o empoderamento de grupos e indivíduos para autogerenciarem sua saúde, sem esquecer a influência direta e objetiva do ambiente (físico e social) nessas ações 
(DIÓGENES; PAGLIUCA, 2003; OMS, 1998). No caso do presente estudo destaca-se a percepção dos professores sobre as práticas do cuidar de si, bem como se verifica a implementação das intervenções de apoio para a promoção da saúde baseadas no local de trabalho - e as lacunas encontradas devem servir de subsídio para priorização e revisão das políticas de promoção da saúde dentro da FEF/UnB.

É praticamente unânime o domínio do discurso dos professores da FEF sobre as práticas corporais e atividade física. No entanto, para se configurar como uma atividade de cuidado promotora de saúde, é fundamental que sua prática parta de sujeitos empoderados, superando a dimensão prescritiva, e que seus benefícios não sejam reduzidos à dimensão biológica do ser humano (ASSUMPÇÃO; MORAIS; FONTOURA, 2002; DIÓGENES; PAGLIUCA, 2003). A grande questão atual é promover a saúde, fortalecer a autonomia dos sujeitos, com respeito às diferenças, potencializando as capacidades individuais, sociais e coletivas, levando em conta o contexto real em que as pessoas vivem, trabalham e fazem a vida acontecer (BACKES et al., 2009).

Precisa-se ainda levar em consideração que as práticas de cuidado de si dizem respeito a cada indivíduo (empoderado), respeitando-se a cultura, e com apoio do ambiente de trabalho. $\mathrm{O}$ cuidar de si não é uma prática específica relativa a uma formação acadêmica, pois todo e qualquer indivíduo deveria se preocupar e ser capaz de cuidar de si. Pode-se perceber nas falas dos professores aspectos sobre o cuidar de si e de sua saúde. As esferas mencionadas são as práticas físicas, mentais, espirituais e emocionais, aproximando-se mais de uma perspectiva integral da saúde, na qual se pode denotar que o conceito de saúde implica abarcar a integralidade do cuidado em saúde pela apreensão do ser humano como um ser integral e complexo (BACKES, 2008).

Nesse sentido, o cuidar de si mantém estreita relação com os princípios de promoção da saúde. O cuidado de si está relacionado diretamente com as práticas corporais e a atividade física favorece os princípios de empoderamento, da autonomia e da equidade no acesso e na produção do cuidado e de modos de vida saudáveis, incentivando a melhoria dos espaços públicos, sem ignorar a cultura local (CARVALHO; NOGUEIRA, 2016; LAZZAROTTI FILHO et. al., 2010; OPAS, 1986).

É possível identificar algumas características gerais na análise conjunta dos estudos demonstrando inter-relação com a saúde, o trabalho e o cuidar de si. A primeira é um fenômeno amplo e complexo e evidencia que já existe um esforço por parte de alguns profissionais no sentido de ampliar o conceito de saúde em relação aos determinantes sociais 
de saúde (BUSS; FILHO, 2007). As condições de trabalho do professor influenciam os processos de saúde (LEMOS, 2005). O cuidado de si mesmo (apoiado ou não pela instituição) é um dos aspectos do viver saudável e consiste na realização de ações dirigidas a si mesmo ou ao ambiente, a fim de regular o funcionamento de ambos, segundo seu interesse na vida e no bem-estar (OREM, 1991).

A atividade do cuidar de si não constitui um exercício de solidão, mas uma verdadeira prática social. Para cuidar de si, o ser humano não pode ser reduzido à dimensão biológica, pois é fruto de um processo e de relações sociais e ambientais bem mais amplas e abrangentes (ASSUMPÇÃO; MORAIS; FONTOURA, 2002). Nesse ponto surge uma pergunta instigante: como um professor de educação física terá condições de cuidar do outro, se não se está disponível para cuidar de si?

Essa discussão se faz pertinente, pois o desafio dos docentes que se cuidam enquanto ensinam é continuar a ser um agente de transformação - onde a prática docente se torna um vetor importante nos processos de subjetivação dos sujeitos em formação e na potencialização das IES para que invistam na promoção da saúde, tanto em sua perspectiva individual quanto coletiva (GARCIA; OLIVEIRA; BARROS, 2008; SILVÉRIO et al., 2010).

Parece óbvio que os resultados dos questionários e das entrevistas se repetiriam em várias dimensões e categorias respectivamente, porém as diversas estratégias relatadas pelos professores de educação física da FEF se direcionaram predominantemente para as práticas pontuais de atividade física. Destacam-se assim os benefícios, revelando um fenômeno reducionista: os conceitos de promoção da saúde e práticas corporais ou atividades físicas em geral norteiam seus discursos (mas não necessariamente suas práticas).

Em relação ao ambiente físico da FEF, pode-se considerar um local propício para as práticas corporal e de atividade física que contribuem para um ambiente de trabalho saudável - estimulam assim os professores a buscar ações para promover essas práticas dentro ou fora desse ambiente. As iniciativas da promoção de saúde, especialmente nos ambientes de trabalho, tendem a adotar a atividade física como uma das principais ferramentas (BRASIL, 2011).

\section{Relações entre a saúde e o prazer e sofrimento no contexto de trabalho}

O trabalho pode fornecer realização, satisfação, prazer, estrutura e forma ao processo de identidade dos sujeitos, mas também pode se tornar elemento causador de doenças, e redução da qualidade de vida do profissional, a depender do tipo de trabalho e pela forma 
como o mesmo está organizado (DELCOR; ARAÚJO; REIS, et al., 2004). No entanto, muitas vezes não se encontra respaldo suficiente para que determinados processos de adoecimento sejam qualificados como relacionados ao trabalho, principalmente no campo da mental em virtude da ausência do caráter "palpável" encontrado nos problemas que atingem diretamente o corpo (BORSOI, 2007).

A despeito de reconhecermos o contexto do trabalho como uma variável que pode afetar positiva e negativamente a vida e a saúde dos trabalhadores, destacamos que os processos de prazer e sofrimento são decorrentes de vivencias subjetivas, muitas vezes inconscientes, resultantes do confronto entre a história de vida do indivíduo e a realidade de trabalho (FERREIRA, 1988). Neste caso, entendemos o prazer e o sofrimento no trabalho como indicadores da saúde ou do adoecimento (FONTANA; PINHEIRO, 2010), mediados por estratégias e relações individuais e coletivas (SILVA; GARCIA, 2009).

As vivências de sofrimento estão associadas ao contexto de trabalho quando se experimenta o desgaste em relação à atividade laboral, que significa a sensação de cansaço, desânimo e descontentamento com o trabalho (MENDES, 2007a). O sofrimento pode desencadear um processo de adoecimento. Isso porque a energia que não pode ser atenuada no exercício laboral se acumula no psíquico, causando desprazer e tensão. Considerando que tal energia não pode ficar acumulada por muito tempo, findando-se as capacidades de contenção, ela se reflete no corpo (DEJOUR; ADDOUCHELI; JAYET, 2010). Por outro lado, o prazer é vivenciado quando, de modo individual ou coletivo, os empregados experimentam sentimento de valorização e reconhecimento no trabalho, advindos das vivências de liberdade de expressão e de realização profissional nas atividades que desenvolvem. O sentimento de ser livre para pensar, bem como para organizar e falar sobre o trabalho e o sentimento de gratificação, de orgulho e de identificação com o trabalho realizado e que atende às necessidades profissionais apresentam ligação direta com a motivação, o prazer e o bem estar (MENDES, 2007). Nessa perspectiva, o prazer significa "sensação ou sentimento agradável, harmonioso, que tende a uma inclinação vital, de alegria, contentamento, satisfação, deleite" (FERREIRA, 1988, pág.523).

No entanto, é importante destacar que embora as pessoas, de um modo geral, busquem para si experiências boas que lhe promovam satisfação e alegria e tentem evitar o desprazer, o funcionamento psíquico humano também pressupõe uma dose de sofrimento (GUIMARÃES, 2005). A ressignificação do sofrimento e a superação dos obstáculos podem estimular o processo criativo resultando em fonte de prazer e realização pessoal (COUTINHO; MAGRO; 
BUDDE, 2011; DEJOURS, 1999). Assim, devemos considerar as vivencias e os saberes profissionais como personalizados e situados. Personalizados devido à história própria do professor, um ser humano com personalidade, cultura e crenças próprias, incorporadas à sua vida; e situados, pois se relacionam às experiências e situações de atuação, construídos e utilizados em função do contexto do trabalho (TARDIF, 2000).

As contradições e ambiguidades do contexto do trabalho, onde o clima organizacional, as relações sociais, o ambiente e o indivíduo compõem conjuntamente as fontes de satisfação, realização e sofrimento, afetam diretamente o bem estar, a saúde e a qualidade de vida de todos os envolvidos (SANTOS, 2013; SILVÉRIO et al., 2010).

Rotinas e cargas de trabalho aceleradas e fatigantes nas IES resultam em menos tempo para o lazer e o convívio familiar, tornando o docente mais vulnerável ao sofrimento (FONTANA; PINHEIRO, 2010). Quando não ressignificadas, as fontes de sofrimento podem gerar angústia, insatisfação, tensão, distúrbios psíquicos, adoecimento e aumentar o absenteísmo (DEJOURS, 1987; LIMA; FILHO, 2009; MARQUEZE; MORENO, 2009).

Por outro lado, o exercício da profissão de professor, que se revela no ato de ensinar e aprender, de aprimorar o crescimento individual e do próximo, e do cuidado consigo e com o outro; e a valorização, o reconhecimento e o apoio institucional dos gestores e alunos à essas atividades apresentam forte relação com o discurso de satisfação com a atividade docente (FLEURY, 2013; FONTANA; PINHEIRO, 2010; MENDES; SILVEIRA; GALVÃO, 2008).

Nessa perspectiva, o apoio institucional contribui de forma acentuada para a promoção da saúde do trabalhador (ARROYO; RICE, 2009). Nas universidades, mudanças estruturais ainda constituem grandes desafios, mas são de fundamental importância para a integração ensino-serviço-comunidade e a valorização do docente (UNESP, 2015).

O trabalho constitui para os professores um importante espaço de inserção social e de estabelecimento de relações interpessoais (COUTINHO; MAGRO; BUDDE, 2011), e ao mesmo tempo pode fornecer realização, satisfação, prazer, estrutura e forma ao processo de identidade dos sujeitos (DELCOR; ARAÚJO; REIS et al., 2004). Por outro lado, também pode se tornar elemento causador de exaustão física e mental associado à precarização das condições trabalho e consequente aumento da carga laboral (COUTINHO; MAGRO; BUDDE, 2011; GARCIA; OLIVEIRA; BARROS, 2008).

Ao buscar compreender os processos de prazer e sofrimento identifica-se como vivências subjetivas, muitas vezes inconscientes, resultantes do confronto entre a história de vida do indivíduo e a realidade de trabalho (FERREIRA, 1988). O próprio docente é capaz de 
procurar estratégias de melhoria na qualidade de vida resgatando a função social de prazer e de solidariedade nas relações de trabalho por meio das transformações externas e internas. A instituição, por sua vez, tem seu papel no suporte e apoio, bem como no cuidado com a saúde dos docentes e sua relação com o ambiente de trabalho (LAGO et al., 2015; SANTOS, 2006). Para Garcia, Oliveira e Barros (2008), o docente é capaz de desenvolver estratégias para lidar com as adversidades do ambiente e os ditames institucionais, resgatando a função social de prazer e solidariedade nas relações de trabalho.

No que se refere ao sofrimento no trabalho, bem como às condições estressoras e ao aumento do risco de transtornos mentais (COUTINHO; MAGRO; BUDDE, 2011; FERREIRA et al., 2015; GONÇALVES; PIRES, 2015), uma estratégia relevante é a busca de projetos profissionais alternativos que confiram valor, prazer e realização à atividade laboral (COUTINHO; MAGRO; BUDDE, 2011).

Normalmente as entrevistas com os professores da FEF trazem ponderações sobre o sofrimento dentro das relações interpessoais (falta de entrosamento e tensionamentos) e o prazer existente na satisfação em ser professor (saúde emocional). As práticas de cuidado de si (atividade física e práticas corporais) e os achados do questionário denotam que a UnB não oferece suporte organizacional para o gerenciamento de estresse.

Os estudos de Santos (2013) e Silvério (2010) - que buscaram expressar as contradições e ambiguidades do meio acadêmico - concluíram que o clima organizacional, as relações e o indivíduo compõem conjuntamente as fontes de satisfação, realização e/ou sofrimento no trabalho, afetando diretamente o bem-estar, a saúde e a qualidade de vida dos docentes.

Foram registrados relatos negativos dos professores sobre o estresse e a saúde mental. Da mesma forma, os docentes da área da saúde de uma universidade no Paraná atribuíram seu estresse, entre outros fatores, à sobrecarga de trabalho e acúmulo de papéis (CHRISTOPHORO; WAIDMAN, 2002). Assim, pode-se afirmar que o estresse associado à docência é fenômeno que necessita de um olhar mais cuidadoso e científico. A docência é uma profissão que comporta riscos para a saúde do professor e requer, portanto, estratégias que auxiliem na preservação de sua integridade física e psicológica (COSTA; ROCHA, 2013).

Se o estresse, quando gerenciado, pode ser benéfico, colaborando para o enfrentamento de situações difíceis, tanto pessoais quanto profissionais, quando fora de 
controle, pode trazer sérias consequências para a saúde (SERVILHA, 2005). Segundo o mesmo autor,

Fica patente à necessidade de urgência em se desenvolver trabalhos de conscientização sobre o estresse e seu gerenciamento, junto aos docentes universitários. Isso, tendo em vista a valorização do docente, tanto como profissional da educação, cujo trabalho é essencial para um país que pretende ser democrático e desenvolvido, quanto como ser humano e cidadão, cujos direitos à vida, à saúde e ao bem-estar devem ser respeitados (pág.50).

Embora esse não seja o foco do presente estudo, a literatura relata que o estresse e a insatisfação são conceitos inter-relacionados, significando que estressores no trabalho contribuem para a insatisfação, que ajuda a aumentar os níveis de estresse (ABOUSERIE, 1996). É preciso procurar compreender, em pesquisas futuras, essa relação. As IES devem planejar ações de saúde destinadas a conscientizar seu quadro de funcionários (professores, administração, estudantes etc.), com foco em cuidar da saúde e como gerenciá-la, interferindo nos fatores que perpassam e determinam sua saúde de forma global.

\section{A Universidade de Brasília e a FEF, promotoras (ou não) da saúde}

Ser professor é uma atividade profissional que exige clareza do papel do conhecimento nos processos de ensinar e aprender para formar profissionais capazes de transformar os conhecimentos aprendidos na universidade em atuações necessárias ao ambiente social em que estão inseridos, inclusive para o próprio docente (ULRICH, 2005). Assim, torna-se fundamental compreender o ser humano como um ser singular e multidimensional inserido em um contexto real e concreto de trabalho (DALMOLIN et al., 2011).

Outra publicação revelou que, embora a maior responsabilidade pela qualidade do ensino superior recaia sobre os professores e alunos, é mister lembrar que essa responsabilidade deve ser compartilhada com a IES, seus líderes, o governo, as associações enfim, toda a comunidade universitária precisa se sentir compromissada e contribuir para o desenvolvimento de um ambiente favorável e de boas práticas no ensino superior (CHICKERING; GAMSON, 1987).

De acordo com a proposta da Organizacion Panamericana de la Salud, citada por Lange e Vio (2006), as universidades promotoras de saúde devem possuir algumas características: 
Ter políticas institucionais para propiciar ambientes favoráveis à saúde, definindo objetivos claros para a promoção da saúde e de segurança para toda a comunidade e explorando a disponibilidade dos recursos universitários para apoiar ações de promoção da saúde; realizar ações de formação acadêmica profissional em promoção da saúde e educação para a saúde, em comunicação em saúde e outras modalidades de capacitação da comunidade universitária; desenvolvendo em simultâneo ações de investigação e avaliação em ambas as áreas; Oferecer serviços preventivos e de cuidados de saúde; oferecer opções de participação para o desenvolvimento de habilidades, liderança e advocacia em saúde nos integrantes da comunidade universitária; com alcance familiar e comunitário (pág. 24).

A implementação de uma universidade saudável representa um processo contínuo que influi praticamente em todas as áreas da instituição incluindo os seus funcionários, investigadores, autoridades, estudantes e as instalações. Por isso, é importante reconhecer que não se trata simplesmente de uma campanha informativa relacionada com a mudança de hábitos, mas de uma mudança na estrutura institucional (SILVA; BRITO, 2014).

As informações reunidas no presente no trabalho sugerem a necessidade de um olhar abrangente sobre as relações entre condições, ambientes e sujeitos, no qual a compreensão dos processos de saúde e adoecimento é obtida com base na dinâmica social que constitui o trabalho. Promover e cuidar da saúde de docentes, dentro da IES, implica reconhecer que diversos elementos, tais como a trajetória individual, os aspectos organizacionais, o ambiente e as relações sociais presentes nas instituições em que esses trabalhadores estão inseridos, são fundamentais para a qualidade de vida e a saúde dos docentes (COUTINHO; MAGRO; BUDDE, 2011; ROHDE , 2012).

Diante desse cenário, são necessárias políticas voltadas para a redução da sobrecarga mediante uma gestão que priorize melhorias nas condições de trabalho, incluindo recursos e fomentos para a concretização digna e a valorização do docente no ensino, seja na pesquisa ou na extensão. Vale destacar aqui o referencial teórico das Universidades Promotoras de Saúde (UPS), onde as IES, na condição de espaço de interação social, devem aliar a vontade política à suficiência de recursos humanos, financeiros e estruturais de forma a melhorar a saúde e a qualidade de vida da comunidade universitária (MELLO; MOYSÉS; SAMUAL, 2009; ROCHA, 2008).

Como afirmado anteriormente, o trabalho docente é peça fundamental para promover o empoderamento, a autonomia e a participação social (a sua própria e a da comunidade 
acadêmica) de maneira a contribuir com a promoção da saúde individual e coletiva na IES (MELLO; MOYSÉS; SAMUAL, 2009). Os princípios da promoção da saúde são: concepção holística, intersetorialidade, empoderamento, participação social, equidade, ações multiestratégicas, e sustentabilidade (SICOLI; NASCIMENTO, 2003).

Cabe salientar que a maioria dos professores avalia de forma negativa o suporte oferecido pela UnB para as ações/intervenções de promoção da saúde, podendo assim fornecer indicativos consistentes para a elaboração de estratégias de intervenção e promoção da saúde (PRIESS, 2011), criar alternativas de prevenção e promoção de saúde no ambiente de trabalho, fazendo com que o professor seja agente ativo do processo (GARCIA; OLIVEIRA; BARROS, 2008). Os projetos/intervenções de promoção da saúde devem extrapolar os muros da FEF. Hoje a atenção à saúde requer mudança na concepção de mundo e na forma de utilizar o conhecimento em relação às práticas de saúde, voltando o seu enfoque especialmente para promoção da saúde (BACKES et al., 2009).

Refletindo sobre as ações e serviços oferecidos pela UnB à população do DF e do entorno, é preciso repensar e valorizar as ações de promoção e proteção da saúde, prevenção das doenças e atenção integral às pessoas no ambiente em que vivem, favorecendo a compreensão ampliada do processo saúde/doença (ANDRADE; BARRETO; BEZERRA, 2006; MAGALHÃES; PINTO, 2014). Para tanto, é relevante a abordagem numa perspectiva ampliada com base na multidisciplinariedade, aumentando o escopo e as modalidades oferecidas, a participação social, o empoderamento e o acesso (CARVALHO; NOGUEIRA, 2016) dos públicos envolvidos diretamente com as ações.

\section{Limitações da presente pesquisa}

Alguns aspectos representaram limitações no percurso da presente pesquisa. O primeiro se refere à formação em Educação Física da própria pesquisadora. A pouca experiência, tanto teórica quanto prática, com a perspectiva das Ciências Sociais e Humanas em saúde e, consequentemente, em relação às metodologias quantitativa e qualitativa de pesquisa, adicionada ao tempo limitado de dois anos para a sua realização, acabou por limitar, seja em nível teórico ou metodológico, a exploração do tema. A elaboração e a realização das entrevistas também foram afetadas pela pouca experiência da pesquisadora, fazendo com que alguns tópicos relevantes tenham ficado de fora da conversa. Entre eles, se o professor já trabalhou em outras IES; se os professores que ocuparam cargos administrativos, no momento 
da gestão, atuaram de forma a conciliar a extensão, o ensino, a pesquisa e a parte administrativa; se os professores extrapolam o horário de aula, fora do ambiente de trabalho.

Outra dificuldade se refere à própria extensão e amplitude dos temas relacionados à promoção da saúde dentro das ações da UnB, o que resulta em escassez de estudos similares com professores universitários. O tamanho da amostra também se inclui nesse desafio.

No entanto, os resultados são satisfatórios para um primeiro contato teórico com o tema da promoção da saúde e das metodologias qualitativa e quantitativa em pesquisa. As limitações da primeira experiência certamente servirão como aprendizado para os próximos trabalhos. 


\section{CONCLUSÕES}

Como resultados a partir de um olhar complexo sobre os processos de saúde e adoecimento a partir da dinâmica social que constitui o trabalho dos professores universitários da Educação Física identificamos que os docentes da FEF-UnB desempenham diversas atividades profissionais que, sobrepostas e alinhadas ao modelo produtivista e às condições de trabalho, acabam por representar fonte de sofrimento, angustia e adoecimento. Reconhecemos que diversos elementos do sujeito e do ambiente, tais como a trajetória individual do docente, e as relações sociais, os aspectos organizacionais, e os ambientes de trabalho podem ser agentes promotores de saúde.

A compreensão dos temas abordados na dissertação é sem dúvida bastante complexo pois existe a possibilidade de ressignificar as relações com o trabalho transformando aspectos negativos em fontes de prazer para esses docentes. Nessa perspectiva as práticas corporais podem desempenhar um importante papel ao estimular o contato social, e o ambiente físico da FEF proporciona aos docentes um local para a prática corporal e atividade física, bem como contribui para um ambiente de trabalho saudável.

Para aqueles que apresentam à concepção mais abrangente de promoção da saúde a satisfação profissional decorrentes da produção de conhecimento, do impacto social que suas atividades de trabalho promovem e em especial nas dimensões físicas e sociais é fonte de prazer. O professor de educação física é agente de saúde, não é um simples transmissor de conhecimento, mas um agente de transformação e pode vivenciar sofrimento adicional ao enfrentar o paradoxo "do curador adoecido".

O significado ampliado da promoção da saúde implica em ampliar as possibilidades interativas além da articulação teoria e prática, por meio de debates e discussões que fortaleçam e divulguem a promoção da saúde segundo uma perspectiva ampliada, respeitando os determinantes sociais da saúde, bem como os princípios. Há a necessidade de desenvolvimento e implementação de projetos de promoção da saúde que extrapolem os muros da FEF e permeiem a gestão da UnB e a operacionalização das intervenções deve afetar as práticas dos docentes.

Os resultados da pesquisa podem servir de subsídios na elaboração de estratégias e políticas inovadoras, dinâmicas, ativas e participativas que atendam melhor às necessidades contemporâneas e complexas em educação e promoção da saúde devem ser maximizadas no ambiente universitário. Nessa perspectiva as Instituições de Ensino Superior deveria ser uma 
mola propulsora para promover as ações do autocuidado apoiado e à prática de cuidar de si. Sendo assim, na busca da relação saúde-trabalho, os professores mobilizam recursos disponíveis na busca de soluções criativas para tornar o trabalho possível e, também, obter resultados positivos no exercício de sua profissão.

Esperamos que a dissertação possa contribuir, para o aprimoramento da qualidade das intervenções, quer no âmbito das Universidades Promotoras de Saúde, quer no âmbito do contexto ampliado de promoção da saúde, contextualizando-os frente aos paradigmas dominantes na formação em saúde e às mudanças sociopolíticas contemporâneas. 


\section{PERSPECTIVAS FUTURAS}

No transcorrer da pesquisa, surgiram algumas inquietações, principalmente as decorrentes da complexidade e amplitude de compreender os processos de saúde e adoecimento a partir da dinâmica social que constitui o trabalho e as relações entre condições, ambientes e sujeitos, uma vez que a promoção da saúde, o apoio ao autocuidado, o cuidado de si e as práticas corporais estão fortemente atrelados aos determinantes sociais. Recomendamos dar maior atenção aos docentes universitários em virtude da particularidade e da amplitude de seus processos de trabalho. São muito variadas as atividades que esses docentes desempenham, em especial os que realizam atividades teórico-práticas e atuam com a comunidade, como é o caso dos professores de educação física e de outras profissões da área da saúde.

Dando continuidade as ações dessa pesquisa, a pesquisadora passou no doutorado e irá desenvolver o projeto com os demais docentes da grande área da saúde da UnB. Em adição sugere-se que outros estudos avancem em termos de:

- Mapear as práticas de promoção da saúde sob um olhar ampliado, em especial que possam resultar na implantação e monitoramento de políticas e programas efetivamente engajados com a promoção da saúde nas universidades, tanto nas esferas pessoal e social, quanto institucional.

- Realizar pesquisas similares em outros grupos de professores universitários, considerando-se as diferentes áreas do conhecimento; bem com estudar outros ambientes da UnB tais como o administrativo;

- Compreender o acúmulo de atividades que geralmente as mulheres se submetem, dentro e fora do ambiente universitário;

- Compreender as percepções e ações de promoção que transcendem as metodologias e ideias preventivas, inclusive em relação à formação dos futuros profissionais de Educação Física. 


\section{REFERÊNCIAS BIBLIOGRÁFICAS}

1. ABOUSERIE, Reda. Stress, coping strategies and job satisfaction in university academic staff. Educational Psychology, Hong Kong, v. 16, n. 1, p. 49-56, 1996.

2. ACSM. American College Of Sports Medicine. Diretrizes do ACSM para o teste de esforço e sua prescrição. 7. ed. Rio de Janeiro: Guanabara Koogan, 2007.

3. ANDRADE, L.O.M.; BARRETO, I.C.H.C.; BEZERRA, R.C. Atenção primária à saúde e estratégia saúde da família. In: Campos GWS, Minayo MCS, Akerman M, Drumond Júnior M, Carvalho YM, organizadores. Tratado de Saúde Coletiva. São Paulo, Rio de Janeiro: Hucitec, Abrasco; p. 783-836, 2006.

4. ARAÚJO, D. S. M. S. de; ARAÚJO, Claúdio G.L.S. de. Aptidão física, saúde e qualidade de vida relacionada à saúde em adultos. Revista Brasileira de Medicina do Esporte. Vol. 6. nº 5 - Set/Out, 2000.

5. ARROYO, H. V.; RICE, M. (Coords) La universidad y el desarrollo de las redes acadêmicas y professionales de promoción de la salud y educación para la salud en América Latina. In IV Congreso International de Universidades Promotoras de la Salude, España, 7-9 Octubre 2009 (p. 37). España: Universidade Pública de Navarra, 2009.

6. ARRUDA, Patrícia Cabral de. Ainda somos os mesmos, mas não vivemos como nossos pais: juventude e participação na Universidade de Brasília. 2012. 213 p. Tese (Doutorado em Sociologia) - Universidade de Brasília. Brasília, 2012.

7. ASSUMPÇÃO, L.O.T.; MORAIS P.P.; FONTOURA, H. Relação entre atividade física, saúde e qualidade de vida. Universidade Católica de Brasília. 2002. Disponível em: <http://extensao.cecierj.edu.br/material_didatico/sau2201/aula08_TC01.pdf >. Acesso em 14 de fev. 2016.

8. AZEVÊDO, Paulo Henrique; BARROS, Jônatas de França; AZEVEDO, Aldo Antonio de Azevedo; SUAIDEN, Samir. Administração estratégica e gestão de unidades públicas de ensino superior: a experiência da Faculdade de Educação Física da Universidade de Brasília. Disponível em: 〈http://www.efdeesporte.com/>. Revista Digital. Buenos Aires - ano 10. n. 77. Outubro, 2004. Acesso em 23 de abril 2016.

9. BACKES, D.S. Vislumbrando o cuidado de enfermagem como prática social empreendedora [tese]. Florianópolis: Centro de Ciências da Saúde, Universidade Federal de Santa Catarina - SC; UFSC/PEN. p. 244, 2008

10. BACKES, M. T. S. et al. Conceitos de saúde e doença ao longo da história sob o olhar epidemiológico e antropológico. Rev. Enferm., Rio de Janeiro, v. 17, n. 1, p. 11-117, jan./mar. 2009. Disponível em: 〈http://www.facenf.uerj.br/v17n1/v17n1a21.pdf> Acesso em: 12 fev. 2016.

11. BARDIN. L. Análise de conteúdo. Lisboa: Editora. Edições 70, 1977. 
12. BAUMAN Z. Modernidade líquida. Rio de Janeiro: Jorge Zahar Ed., 2001.

13. BORGES, T. T. et al . Conhecimento sobre fatores de risco para doenças crônicas: estudo de base populacional. Cadernos de Saúde Pública, Rio de Janeiro, v. 25, n. 7, 2009. Disponível em <http://www.scielo.br/pdf/csp/v25n7/09.pdf.> Acesso: 20 abril 2015.

14. BORSOI, I.C.F. da. Relação entre Trabalho e Saúde à Relação entre Trabalho e Saúde Mental. Universidade Federal do Ceará, Fortaleza, Brasil. Psicologia \& Sociedade; 19, Edição Especial 1: 103-111, 2007.

15. BORTOLETTI, Vanessa Alves. Anísio Teixeira e o projeto da Universidade Brasileira: UDF e UNB. Anais Elet Univ Fed da Paraíba. João Pessoa, 2012.

16. BOSI, M.L.M. PAIM, J.S. Graduação em Saúde Coletiva: limites e possibilidades como estratégia de formação profissional. Ciência \& Saúde Coletiva, 15(4):2029-2038, 2010.

17. BOSI, M.L.M. Pesquisa qualitativa em saúde coletiva: panorama e desafios. Ciência \& Saúde Coletiva, 17(3):575-586, 2012.

18. BOSI, M.L.M; PRADO, S.D. Food and Nutrition in Public Health: constitution, contours and scientific status. Ciência \& Saúde Coletiva, v. 16, n. 1, p. 7-17, 2011.

19. BOTH, Jorge; NASCIMENTO, Juarez Vieira Do; BORGATT, Adriano Ferreti. Percepção da Qualidade de Vida no Trabalho e Perfil do Estilo de Vida dos Docentes de Educação Física do Estado de Santa Catarina. R. da Educação Física/UEM. Maringá, v. 19, n. 3, p. 377-389, 3. trim. 2008.

20. BRACHT, Valter. Sociologia crítica do esporte: uma introdução. Coleção Educação Física. Ijuí: Unijuí. 2005; Castiel, Luis David; Sanz-Valero, Javier \& Vasconcellos-Silva, Paulo Roberto. Das loucuras da razão ao sexo dos anjos: biopolítica, hiperprevenção, produtividade científica. Rio de Janeiro: Fiocruz, 2011.

21. BRANCO, M.C.C.C. Brasília: Narrativas Urbanas. 2006. 142 f. Dissertação (Mestrado) - Curso de Sociologia, Sociologia, Universidade de Brasília, Brasília, 2006.

22. BRASIL. Relatório Final da $\mathbf{8}^{\text {a }}$ Conferência Nacional de Saúde. 17 a 21 março de 1986.

23. Ministério da Saúde. Projeto Promoção da Saúde. As Cartas da Promoção da Saúde. Secretaria de Políticas de Saúde. Ministério da Saúde, Secretaria de Políticas de Saúde, Projeto Promoção da Saúde. - Brasília: Ministério da Saúde, 2002.

24. O Que é REUNI. Disponível em: <http://reuni.mec.gov.br/o-que-e-o-reuni>; Acesso em: 06 set. 2015. 2003.

25. Ministério da Saúde. Política nacional de práticas integrativas e

complementares no SUS - PNPIC-SUS. Secretaria de Atenção à Saúde. Departamento de Atenção Básica. Série B. Textos básicos em saúde. Brasília, DF, 2006a. 
26. Ministério da Saúde. A Educação Permanente entra na roda: Pólos de

Educação Permanente em Saúde: Conceitos e caminhos a percorrer. Secretaria de Gestão do Trabalho e da Educação na Saúde. Departamento de Gestão da Educação na Saúde. MS/SGETES/ DEGES/2. ed. Brasília: Ministério da Saúde, 2006.

27. Ministério da Saúde. Política nacional de promoção da saúde / Ministério da Saúde, Secretaria de Atenção à Saúde. Secretaria de Vigilância em Saúde - Brasília: Ministério da Saúde, Série B. Textos Básicos de Saúde, 60 p., 2006.

28. Ministério da Saúde. Minuta da Portaria de revisão da Política Nacional de Promoção da Saúde. Secretaria de Vigilância em Saúde. Departamento de Vigilância de Doenças e Agravos Não Transmissíveis e Promoção da Saúde - DANTPS. Ministério da Saúde, Secretaria de Atenção à Saúde. - Brasília: Ministério da Saúde, 2014. 24 p. Aprova a Política Nacional de Promoção da Saúde a partir da revisão da Portaria nº 687, de 30 de março de 2006.

29. Ministério da Saúde. Política Nacional de Promoção da Saúde. Secretaria de Vigilância em Saúde. Secretaria de Atenção à Saúde. Ministério da Saúde, Secretaria de Vigilância em Saúde, Secretaria de Atenção à Saúde. - 3. ed. - Brasília : Ministério da Saúde, 2010.

30. Ministério da Saúde. Estratégias para o cuidado da pessoa com doença crônica Secretaria de Atenção à Saúde. Departamento de Atenção Básica. / Ministério da Saúde, Secretaria de Atenção à Saúde, Departamento de Atenção Básica. Brasília: Ministério da Saúde, 2014.

31. Ministério da Saúde. Política Nacional de Promoção da Saúde: PNPS: revisão da Portaria MS/GM n⿳0 687, de 30 de março de 2006. Secretaria de Vigilância em Saúde. Secretaria de Atenção à Saúde. Ministério da Saúde, Secretaria de Vigilância em Saúde, Secretaria de Atenção à Saúde. - Brasília: Ministério da Saúde, 2015.

32. BRASÍLIA. Região Integrada de Desenvolvimento do Distrito Federal e Entorno. Disponível em: $<$ https://pt.wikipedia.org/wiki/Regi\%C3\%A3o_Integrada_de_Desenvolvimento_do_Distrito_ Federal_e_Entorno >. Acesso em: 28 jun. 2016.

33. BREILH, J. Epidemiologia crítica: ciência emancipatória e interculturalidade. Rio de Janeiro: Editora Fiocruz. 317 pp. ISBN: 85-7541-095-4, 2006.

34. BUB, M.B.C.; MEDRANO C.; SILVA C.D.; WINK S., LISS P.E.; SANTOS E.K.A. A Noção de Cuidado de Si Mesmo e o Conceito de Autocuidado na Enfemargem. Texto Contexto Enferm, Florianópolis. v.15 (Esp): p.152-7, 2006.

35. BUSS, P.M. Promoção da saúde e qualidade de vida. Ciência e Saúde Coletiva, Rio de janeiro, v. 5, n. 1, p.163-177, 2000.

36. BUSS, P. M; PELLEGRINI FILHO, Alberto. A saúde e seus determinantes sociais. Physis: Rev. Saúde Coletiva, Rio de Janeiro, v. 17. n.1. p.77-93, 2007. 
37. BUSS P.M.; CARVALHO A.I. Desenvolvimento da promoção da saúde no Brasil nos últimos vinte anos (1988-2008). Cien Saude Colet. 14(6):2305-2316, 2009.

38. CAMPOS, G. W. S. Saúde Paidéia. São Paulo: Hucitec, 2003.

39. Clínica e Saúde Coletiva Compartilhadas: Teoria Paidéia e Reformulação Ampliada do Trabalho em Saúde. Tratado de Saúde Coletiva. Revista Fiocruz; 2006.

40. CAPES. História e missão. Disponível em: <http://www.capes.gov.br/historia-emissao >. Publicado: Terça, 17 Junho 2008 10:28. Última atualização: Segunda, 11 Maio 2015 12:54; Acesso em: 02 mar. 2016.

41. CARVALHO, S. R. Saúde coletiva e promoção à saúde: uma reflexão sobre os temas do sujeito e da mudança. Tese (Doutorado em Saúde Coletiva) - Faculdade de Ciências Médicas, Universidade Federal de Campinas, Campinas, 2002.

42. Saúde Coletiva e Promoção da Saúde: Sujeito e Mudança. São Paulo:

Editora Hucitec. 183 pp., 2005.

43. CARVALHO, M.R.G. de. Breves reflexões suscitadas pelo artigo "Política de cotas raciais, os 'olhos da sociedade' e os usos da antropologia: o caso do vestibular da Universidade de Brasília (UnB). Horiz. antropol., Porto Alegre , v. 11, n. 23, p. 264-267, June 2005.

44. CARVALHO, Y.M. Práticas corporais e comunidade: um projeto de educação física no Centro de Saúde Escola Samuel B. Pessoa (Universidade de São Paulo). Educação física e saúde coletiva: políticas de formação e perspectivas de intervenção / organizado por Alex Branco Fraga e Felipe Wachs. - Porto Alegre: Editora da UFRGS, 2007.

45. CARVALHO, F.F.B.de.; NOGUEIRA, J.A.D. Práticas corporais e atividades físicas na perspectiva da Promoção da Saúde na Atenção Básica. Ciência \& Saúde Coletiva, v. 21. n.6 p.1829-1838, 2016.

46. CASPERSEN, C. J.; POWEL, K. E.; CHRISTENSON, G. M. Physical activity, exercise, and physical fitness: definitions and distinctions for health-related research. Public Health Reports, v. 100, n. 2, p. 126-131, 1985.

47. CAVALCANTI, A.M., OLIVEIRA, A.C.L.de. Autocuidado Apoiado: Manual do Profissional de Saúde. Curitiba: Secretária Municipal da Saúde. 92p., 2012.

48. CDC. Centers For Disease Control And Prevention. The CDC Worksite Health ScoreCard: An Assessment Tool for Employers to Prevent Heart Disease, Stroke, and Related Conditions. Atlanta: US Department of Health and Human Services, 2012.

49. . The CDC Worksite Health ScoreCard: An Assessment Tool for Employers to Prevent Heart Disease, Stroke, and Related Health Conditions. Atlanta: U.S. Department of Health and Human Services, 2014. 
50. CECCIM, R.B.; BILIBIO, L.F. Singularidade da Educação Física na saúde: desafios à educação de seus profissionais e ao matriciamento interprofissional. Educação física e saúde coletiva: políticas de formação e perspectivas de intervenção / organizado por Alex Branco Fraga e Felipe Wachs. - Porto Alegre: Editora da UFRGS, 2007.

51. CHICKERING, A.W; GAMSON, Z.F. Seven principles for good practice in undergraduate education. AAHE Bulletin, Grandview, v. 3, p. 7, 1987.

52. CHRISTOPHORO, R.; WAIDMAN, M. A. P. Estresse e condições de trabalho: um estudo com docentes do curso de enfermagem da UEM, Estado do Paraná. Acta Scientiarum. Health Sciences, v. 24, n. 3, p. 757-763, 2002.

53. CNS. Conselho Nacional de Saúde. Resolução CNS n 287 de 08 de outubro de 1998.

54. CODEPLAN.Companhia de Planejamento do Distrito Federal. Distrito Federal: Síntese de Informações Socioeconômicas. Brasília: Codeplan, 2013.

55. .Companhia de Planejamento do Distrito Federal. Distrito Federal: Síntese de Informações Socioeconômicas, Brasília : Codeplan, 2014, 93 p.

56. CODO, W. Educação: carinho e trabalho. Rio de Janeiro: Vozes, (coord), 1999.

57. COSTA, F.R.C.P.; ROCHA, R. Fatores estressores no contexto de trabalho docente. Revista Ciências Humanas - UNITAU. Taubaté-SP - Brasil. 43. v. 6, n.1, p. 18-43. jan.jun./2013

58. COUTINHO, M.C.; MAGRO, M.L.P.D; BUDDE, C. Entre o prazer e o sofrimento: um estudo sobre os sentidos do trabalho para professores universitários. Psicologia: Teoria e Prática - Universidade Federal de Santa Catarina, Florianópolis, SC. Br. v.13. n.2 p.154-167, 2011.

59. CZERESNIA, Dina. Categoria vida: reflexões para uma nova biologia. São Paulo: Editora Unesp; Rio de Janeiro: Editora Fiocruz, 2012.

60. DAHLGREN, G; WHITEHEAD, M. Policies and strategies to promote social equity in health. Arbetsrapport/Institutet för Framtidsstudier, 2007. Disponível em:

<http://www.framtidsstudier.se/filebank/files/20080109\$110739\$fil\$mZ8UVQv2wQFSMRF 6cuT.pdf>. Acesso em: 26 jun. 2016.

61. DALLACOSTA, F.M. Avaliação do nível de satisfação no trabalho e dos sintomas de Burnout em docentes da área da saúde. 190 f. Tese (Doutorado) - Faculdade de Medicina, PUCRS. Porto Alegre; 2014.

62. DALMOLIN, B.B.; BACKES, D.S.; ZAMBERLAN, C.; SCHAURICH, D.; COLOMÉ, J.S.; GEHLEN, M.H. Significados do Conceito de Saúde na Perspectiva de Docentes da Área da Saúde. Esc Anna Nery (Impr.) Abr -Jun; v.15. n.2. p.389-394, 2011.

63. DE OLIVEIRA, L. Promoção da saúde na Educação Física Escolar: concepções e propostas na perspectiva de Professores do Ensino Público Estadual da Região Centro-Oeste 
do Município de São Paulo. Motriz. Revista de Educação Física. UNESP, Rio Claro, 16, fev. 2010. Disponível em:

<http://www.periodicos.rc.biblioteca.unesp.br/index.php/motriz/article/view/1980-

6574.2010v16n2p535/3027> Acesso: 20 abril 2015.

64. DEJOURS, C. A Loucura do Trabalho: Estudo de Psicopatologia do Trabalho. São Paulo: Cortez, 1987.

65. . Conferências brasileiras: identidade, reconhecimento e transgressão no trabalho. São Paulo: Fundap, 1999.

66. Sofrimento, prazer e trabalho. In: Dejour C. Conferências Brasileiras: identidade, reconhecimentoe transgressãonotrabalho São Paulo: FGV. p.15-33, 1999.

67. DEJOURS, C.; ABDOUCHELI, E.; JAYET, C. Psicodinâmica do Trabalho: Contribuições da escola dejourina à a análise de relação prazer, sofrimento e trabalho. Coordenação Irene Stocco Betiol. 1 ed. 11ª reimpressão São Paulo: Atlas, 2010.

68. DELCOR, N.S.; ARAÚJO, T.M.; REIS, .E.J.F.B.; PORTO, L.A.; CARVALHO, F.M.; SILVA, M.O. et al. Condições de trabalho e saúde dos professores da rede particular de ensino de Vitória da Conquista, Bahia, Brasil. Cad. Saúde Pública [internet]. 2004 ;20(1): 187-96. Disponível em: <http://www.scielo.br/pdf/csp/v20n1/35.pdf $>$. Acesso em: 20 maio 2016.

69. DEMARCO, T.; SIDNEY, K. Enhancing children's participation in physical activity. J Sch Health. v.59. p.337-40, 1989.

70. DEVIDE, Fabiano Pries. Educação Física Escolar como via de Educação para Saúde. A Saúde em Debate na Educação Física. Marcos Bagrichevsky, Alexandre Palma e Adriana Estevão. Blumenau (SC). Edibes, 2003.

71. DF. Anuário do DF: 2010: uma ferramenta de fomento ao turismo e ao desenvolvimento do Distrito Federal. Mark Consultoria. Ano 1, n. 1, maio. 2010. - Brasília, 2010.

72. DIÓGENES M.A.R.; PAGLIUCA L.M.F. Teoria do autocuidado: análise crítica da utilidade na prática da enfermeira. Rev. Gaúcha Enferm, Porto Alegre (RS). dez; v.24. n.3. p. 286-93, 2003.

73. DOYLE, E.I.; FELDMAN, R.H.L. Are local teachers or nutrition experts perceived as more effective among Brazilian high school students? Journal of School Health, Kent OH, v. 64, n. 3, 1994.

74. ESTEVE, J. M. Mal-estar docente: a sala de aula e a saúde dos professores. São Paulo: Edusc., 1999.

75. FACAS, E. P. ; MACHADO, A. C. A.; MENDES, A. M. BA Negação do saber operário no trabalho automatizaste: analise psicodinâmica do trabalho de pilotos de trem de metro do Distrito Federal. Revista Amazônica, v. IX, p. 44-68, 2012. 
76. FACAS, E. P. Protocolo de Avaliação dos Riscos Psicossociais no Trabalho Contribuições da Psicodinâmica do Trabalho. 2013. 193 f. Tese (Doutorado em Psicologia Social, do Trabalho e das Organizações) - Instituto de Psicologia, Universidade de Brasília, Brasília. Out. 2013.

77. FERNANDES E.C. Qualidade de vida no trabalho: como medir para melhorar. Salvador, BA: Casa da Qualidade, 1996.

78. FERREIRA, A. B. de H. Dicionário Aurélio básico da língua portuguesa. 1 ed. Rio de Janeiro: nova Fronteira, 687p., 1988.

79. FERREIRA, A.C.M. Satisfação no Trabalho de Docentes de uma Instituição Pública de Ensino Superior. Dissertação de Mestrado. Universidade Federal do Goiás. Faculdade de Enfermagem; 2011.

80. FERREIRA, M. C.; MENDES, A. M. Trabalho e Riscos de Adoecimento: O Caso dos Auditores-Fiscais da Previdência Social Brasileira. Brasília: LPA Edições. 2003.

81. Contexto de Trabalho. Em Siqueira, M. M. M. (org.). Medidas do comportamento organizacional: ferramentas de diagnóstico e gestão. Porto Alegre: Artmed. 2008.

82. FERREIRA, M.S. Aptidão física e saúde na educação física escolar: ampliando o enfoque. Revista Brasileira de Ciências do Esporte, v. 22, n. 2, p. 4154, 2001.

83. FERREIRA, R.C.; SILVEIRA, A.P.da.; SÁ, M.A.B.de.; FERES, S.B.L.; SOUZA, J.G.S.; MARTINS, A.M.E.B.L. Transtorno Mental e Estressores no Trabalho entre Professores Universitários da Área da Saúde. Trab. Educ. Saúde, Rio de Janeiro, v. 13, supl. 1, p. 135-155, 2015.

84. FLEURY, Alessandra Ramos Demito. O trabalho e a docência em uma instituição de ensino superior pública [manuscrito]; o caso dos professores de odontologia da Universidade Federal de Goiás, 2013, Tese (doutorado) - Pontifícia Universidade Católica de Goiás, Departamento de Psicologia, 2013.

85. FONTANA, R.T.; PINHEIRO, D.A. Condições de saúde auto referidas de professores de uma universidade regional. Rev. Gaúcha Enferm., Porto Alegre (RS) jun; v.31. n.2 p.2706,2010 .

86. FONTANELLA, Bruno J. B.; RICAS, Janete; TURATO, Egberto R. Amostragem por saturação em pesquisas qualitativas em saúde: contribuições teóricas. Cad. Saúde Pública, Rio de Janeiro, v.24. n.1. p.17-27, jan, 2008.

87. FOUCAULT, M. As técnicas de si. Trad. de Wanderson Flor do Nascimento e Karla Neves [texto na internet] disponível em <http:www.unb.br/Fe/tef/filoesco/Foucault/techniques.html>. Acesso em fev. 2016. 2007. 
88. GARCIA, A.L.; OLIVEIRA, E.R.A.; BARROS, E.B. Qualidade de Vida de Professores do Ensino Superior na Área da Saúde: Discurso e Prática Cotidiana. Cogitare Enferm. Jan/Mar; v.13. n.1 p.18-24, 2008.

$<$ http://www.cienciasecognicao.org/revista/index.php/cec/article/viewFile/253/136>. Acesso em 03 de out. 2015.

89. GOMES, S.B.S.; BRAUNER, V.L.P. Cuidados de si: (des)regulações necessárias sobre corpo, atividade física e saúde dos cuidadores. Bioética. v.14 . n.2 p. 219-228, 2006.

90. GOMES, J.H. CAETANO, J.R. Educação a Distância, Democracia e

Sustentabilidade. Investigação Científica Setor Educacional:Educação Superior

Classificação das Áreas: Nível meso-Gerenciamento e Organização Natureza do Trabalho:

Relatório Concluído (Tese), 2014.

91. GOMES, L. Trabalho multifacetado de professores/as: a saúde entre limites. 2002. 123p. Dissertação (Mestrado em Saúde Publica)-Fundação Oswaldo Cruz, Rio de Janeiro, 2002. Disponível em:

$<$ http://portalteses.icict.fiocruz.br/transf.php?script=thes_cover\&id=000094\&lng=pt\&nrm=is o>. Acesso em: 11 março. 2016. 2002.

92. GONÇALVES, A.S.R.; PIRES, D.E.P. O trabalho de docentes universitários da saúde: situações geradoras de prazer e sofrimento. Rev enferm UERJ, Rio de Janeiro:mar/abr; v.23. n. 2 p. $266-71 ; 2015$.

93. GUARANY, A.M.B. Trabalho Docente, Carreira Doente: a privatização, a lógica produtivista e a mercantilização na e da educação e seus efeitos sobre os docentes. Revista Educação por Escrito - PUCRS, v.3, n.1, jul. 2012.

94. GUBA E.G.; LINCOLN, Y.S. Avaliação de quarta geração. Campinas, SP: Editora da Unicamp; 2011.

95. GUIMARÃES, F.A.L. Realização Profissional, Prazer e Sofrimento no Trabalho e Valores: um estudo com profissionais de nível superior. (Dissertação de mestrado) Universidade Federal de Uberlândia. Programa de Pós Graduação em Psicologia. 2005.

96. IBGE. Instituto Brasileiro de Geografia e Estatística. Ministério do Planejamento e Gestão. Contas Nacionais n⿳0. 43. Produto Interno Bruto dos Municípios, 2012.

97. INEP. Instituto Nacional de Estudos e Pesquisas Educacionais Anísio Teixeira. Censo da educação superior 2013: resumo técnico. - Brasília: Instituto Nacional de Estudos e Pesquisas Educacionais Anísio Teixeira, 2015.

98. JUNG, C.G. Memories, Dreams, Reflections. New York: Vintage Books; 1989.

99. LA FALCE, Jefferson L.; GARCIA, Fernando C.; MUYLDER, Cristina F. Prazer e sofrimento: um estudo de caso em um centro de pesquisas brasileiro. Gestão \& Regionalidade. v.27. n. 81. Set-dez/2011.

100. LAGO, R.R.; CUNHA, B.S.; BORGES, M.F.S. O. Percepção do Trabalho docente em uma Universidade da Região Norte do Brasil. Trab. Educ. Saúde, Rio de Janeiro, v. 13 n. 2, 
p. 429-450,maio/ago; 2015. Disponível em: 〈http://dx.doi.org/10.1590/1981-7746-sip00049>. Acesso em: 03 out. 2015.

101. LANGE, I.; VIO, F. Guía para universidades saludables y otras instituciones de educación superior. Santiago de Chile: Universidad de Chile, Instituto de Nutrición y Tecnología de los Alimentos, 2006. Disponível em: <http://www.eligevivirsano.cl/ wpcontent/uploads/2012/01/Guia-Universidades-Saludables_ INTAOPS.pdf >. Acesso em: 25 jan. 2016.

102. LAURELL A.C.; NORIEGA M. Processo de produção e saúde - Trabalho e desgaste operário. São Paulo: Hucitec; 1989.

103. LAURELL, A. C. The role of union democracy in the struggle for workers' health in Mexico. International Journal of Health Services, v.19. n.2. p. 279-293, 1989.

104. LAZZAROTTI FILHO, A, et al. O termo práticas corporais na literatura científica brasileira e sua repercussão no campo da Educação Física. Movimento (ESEF/UFRGS), v. 16, n. 1, p. 11-29, 2010.

105. LEMOS, J.C. Cargas psíquicas no trabalho e processos de saúde em professores universitários [tese]. Florianópolis: Departamento de Engenharia de Produção, Universidade Federal de Santa Catarina; 2005.

106. LIMA, M.F.E.M. ; LIMA, Filho Do. Condições de trabalho e saúde do/a professor/a universitário/a. Ciênc Cogn[Internet]. 2009;14(3):62-82.Disponível em: $<$ http://www.cienciasecognicao.org/revista/index.php/cec/article/viewFile/253/136 $>$. 107. LUDERMIR AB. Inserção produtiva, gênero e saúde mental. Cad. Saúde Publica, v.16. n.3 p.647-659, 2000;

108. LUZ, MADEL T. Educação física e saúde coletiva: papel estratégico da área e possibilidades quanto ao ensino na graduação e integração na rede de serviços públicos de saúde. Educação física e saúde coletiva: políticas de formação e perspectivas de intervenção / organizado por Alex Branco Fraga e Felipe Wachs. - Porto Alegre: Editora da UFRGS, 2007.

109. MACHADO, E. Os efeitos da crise na educação brasileira. Disponível em: $<$ https://edsonmachado.net/2016/02/29/os-efeitos-da-crise-na-educacao-brasileira $>$. Acesso no dia 13 de julho 2016.

110. MAGALHÃES, Júnior H.M.; PINTO, H.A. Atenção Básica enquanto ordenadora da rede e coordenadora do cuidado: ainda uma utopia? Revista Divulgação em Saúde para Debate. v.51. p.14-29, 2014.

111. MAIO, M.C.; SANTOS, R.V. Política de cotas raciais, os "olhos da sociedade" e os usos da antropologia: o caso do vestibular da Universidade de Brasília (UNB). Horizontes Antropológicos, Porto Alegre, v.11, n.23, p.181-214, 2005.

112. MANCEBO D.; SILVA, Jr. João dos Reis [Org.] Trabalho docente e expansão da educação superior brasileira. Rio de Janeiro: EdUERJ; 192p; 2012. 
113. MANCEBO D.; ROCHA M.L. Avaliação na educação superior e trabalho docente. Interações. v. II, n. 13, jan-jun, p. 55-75; 2002.

114. MARQUEZE, E.C.; MORENO, C.R.C. Satisfação no Trabalho e Capacidade para o Trabalho entre Docentes Universitários. Psicologia em Estudo, Maringá, v. 14, n. 1, p. 75-82, jan./mar; 2009.

115. MARTÍNEZ D.; VALLES I.; KOHEN J. Salud y trabajo docente: Tramas do malestar en la escuela. Buenos Aires. Argentina: Kapelusz; 1997.

116. MEDA, Lara R.M.; SANTOS, Ávila F.; LARA; García, B.; VERDUGO, Lucero J.C.; PALOMERA, Chaves A.; VALADEZ, Sierra M. D. Evaluación de la perceptión de calidade de vida y el estilo de vida en estudiantes desde el contexto de las universidades promotoras de la salud. Revistade Educación y Desarrollo, v.5. n.8. p. 5-16, 2008.

117. MELLO, A.L. S. F; MOYSÉS, S.T; MOYSÉS, S.J. A universidade promotora de saúde e as mudanças na formação profissional. Departamento de Odontologia,

Universidade Federal de Santa Catarina. Centro de Ciências Biológicas e da Saúde, Pontifícia Universidade Católica do Paraná, 2009.

118. MENDES, Ana Magnólia. Psicodinâmica a Psicopatologia do Trabalho. Em: Mendes, A. M. (org). Psicodinâmica do Trabalho: teoria, método e pesquisas. São Paulo: Casa do Psicólogo, 2007a.

119. Psicodinâmica do Trabalho: teoria, métodos e pesquisa. São Paulo: casa do Psicólogo, 2007. p. 368.

120. MENDES, A.M.; FERREIRA, M. C. Contexto de Trabalho. In: Mirlene Maria Matias Siqueira. (Org.). Medidas do Comportamento Organizacional: Ferramentas de Diagnóstico e Gestão. Porto Alegre RS: Artmed, 2008, p. 111-123.

121. MENDES, E. V. O Cuidado das Condições Crônicas na Atenção Primária à Saúde: O Imperativo da Consolidação da Estratégia da Saúde da Família. Brasília, DF, Brasil: Organização Pan Americana de Saúde, 2012.

122. MENDES, I.J.M.; NETO, A.B.; JÚNIOR PEREIRA, J. A. Perspectiva de ampliação das funções da unidade básica de saúde: relato de experiência. Rev.latino- am.enfermagem, Ribeirão Preto, v. 4, n. 1, p. 119-29, janeiro 1996.

123. MENDES, K.D.S.; SILVEIRA, R.C.C.P.; GALVÃO, C.M. Revisão Integrativa: Método de Pesquisa para a Incorporação de Evidências na Saúde e na Enfermagem. Rev. Texto Contexto Enferm., Florianópolis, 2008.

124. MINAYO, Maria C.S. Saúde como Responsabilidade Cidadã. A Saúde em Debate na Educação, 2006. 
125. MORELLI, A.L.F. Correio Braziliense: 40 anos - Do pioneirismo à consolidação. Dissertação apresentada à Faculdade de Comunicação da Universidade de Brasília - UnB, abril de 2002.

126. MORETTI, A.C.; ALMEIDA, V.; WESTPHAL, M.F.; BÓGUS, C.M. Práticas Corporais/Atividade Física e Políticas Públicas de Promoção da Saúde. Saúde Soc. São Paulo, v.18, n.2, p.346-354, 2009.

127. MOYSÉS, S.J.; MOYSÉS, S.T.; KREMPEL, M.C. Avaliando o processo de construção de políticas públicas de promoção de saúde: a experiência de Curitiba. Cienc. Saude Colet.,v.9, n.3, p.627-41, 2004.

128. NAHAS, Markus V.; BARROS, Mauro B. G; FONSECA, Silvio. Estilo de vida e hábitos de lazer dos trabalhadores da indústria catarinense (1999-2004): relatório geral. SESI SC, Florianópolis, Sesi, 2004.

129. NAHAS, Markus V.; BARROS, Mauro B. G.; SANTINA, Elusa A.O.; AGUIAR, Fabíola da Silva. Estilo de vida e hábitos de lazer dos trabalhadores das indústrias brasileiras: relatório geral. Brasília : Sesi/DN, 2009.

130. NOGUEIRA, Júlia. A. D. A educação física e a saúde. Humanidades (Brasília), v. 60, p. 102-113, 2014.

131. OLIVEIRA, E.R.A.O.; GARCIA, A.L.; GOMES, M.J.; BITTAR, T.O.; PEREIRA, A.C. Gênero e qualidade de vida percebida - estudo com professores da área de saúde.

Ciência \& Saúde Coletiva, 17(3):741-747; 2012.

132. OLIVEIRA, M. A. M.; FREITAS, M. V. T. Políticas contemporâneas para o ensino superior: precarização do trabalho docente? Revista Extra Classe, v. 2, n. 1, p. 48;59, 2008.

133. OLIVEIRA, M. G. Condições de trabalho, gênero e saúde: sofrimento e estresse. Um estudo de caso com os profissionais docentes do ensino superior privado de Belo Horizonte. 2001. Dissertação (Mestrado em Ciências Sociais)-Pontifícia Universidade Católica de Minas Gerais, Belo Horizonte, 2001.

134. OMS. Preamble to the Constitution of the World Health Organization. WHO, New York, USA. 1946.

135. __ . Organización Mundial De La Salud. Carta de Ottawa para la promoción de la salud. In: Organización Panamericana De La Salud. Promoción de la salud: uma antologia. Washington: OPAS, 1996. p.367-72.

136. __ Tabacco Use Prevention: na important entry point for the developmente o Health Promotion Schools. Geneva: World Health Organization. UNESCO. 1998.

137. __ Global strategy on diet, physical activity and health. Fifty-seventh world health assembly [monograph on the Internet] [WHA57.17]. Available from http: //www.who.int/gb/ebwha/pdf_files/WHA57/A57_R17- en.pdf. 2004. 
138. OPAS. Prevenção de doenças crônicas: um investimento vital. Brasília: Organização Mundial de saúde, 2005.

139. OREM D.E. Nursing: concepts of practice. 4th ed. St Louis (USA): Mosby Year Book Inc.; 1991.

140. PAIM, J.S.; ALMEIDA Filho, N.D. Saúde coletiva: uma "nova saúde pública" ou campo aberto a novos paradigmas? Rev. Saúde Publica, v.32, n.4, p.299-316, 1998.

141. PALMA, A.; ESTEVÃO, A.; BAGRICHEVSKY, M. Considerações Teóricas Acerca das Questões Relacionadas Promoção da Saúde. Saúde Coletiva e Educação Física: aproximando Campos, Garimpando sentidos. A saúde em debate na Educação Física. v. 2. I organizado por Marcos Bagrichevsky, Alexandre Palma, Adriana Estevão, Marco Da Ros. Blumenau: Nova Letra, 2006.

142. PEREIRA MG. Epidemiologia: teoria e prática. $5^{\mathrm{a}}$ ed. Rio de Janeiro: Guanabara Koogan; 2001. p. 469-71.

143. PERIM, G.L.; ABDALLA, I.G.; AGUILAR, D.S.; HENRIQUE, R.; LAMPERT, J.B.; STELLA, R.C.R., et al. Desenvolvimento docente e a formação de médicos. Revista Brasileira de Educação Médica, v.33. Supl.1. p.70-82; 2009.

144. PNAD. Pesquisa Nacional por Amostra de Domicílios. Análise dos Dados da PNAD 2012: Comparativo Distrito Federal e Brasil. CODEPLAN - Companhia de Planejamento do Distrito Federal, 2013.

145. PPP. Projeto Político Pedagógico Institucional da Universidade de Brasília - UnB, Brasília, 07 de julho de 2011.

146. PRIESS, F.G. Características do Estilo de Vida e da Qualidade de Vida de Professores Universitários de Instituições Privadas de Foz do Iguaçu e Região. (Dissertação de Mestrado), no Departamento de Educação Física, Setor de Ciências Biológicas da Universidade Federal do Paraná; 2011.

147. QS. Quacquarelli Symonds. QS University Rankings: Latin America 2014. Acesso: $<$ http://www.topuniversities.com/latin-america-rankings/methodology $>$. Acesso em: $20 \mathrm{de}$ Jun 2016.

148. REUNI. Programa de Reestruturação e Expansão das Universidades Federais. Documento Elaborado pelo Grupo Assessor nomeado pela Portaria $n^{\circ} 552$ SESu/MEC, Brasil, de 25 de junho de 2007, em complemento ao art. $1^{\circ} \S 2^{\circ}$ do Decreto Presidencial $n^{\circ} 6.096$, de 24 de abril de 2007.

149. RIBEIRO, M.R.R.; CIAMPONE, M.H.T. O debate acerca da complexidade dos objetos do trabalho docente na área de saúde. Educação em Revista, Marília, v.9, n.2, p.51-64, jul.dez. 2008.

150. ROCHA, E. Universidades Promotoras de Saúde. Instituto de Medicina Preventiva Faculdade de Medicina de Lisboa, Lisboa, Portugal. Rev Port Cardiol 27 (1): 29-35, 2008. 
151. ROCHA, K.B.; SARRIERA, J.C. Saúde percebida em professores universitários: gênero, religião e condições de trabalho. Revista Semestral da Associação Brasileira de Psicologia Escolar e Educacional (ABRAPEE). v.10. n.2.187-196; Julho/Dezembro 2006.

152. ROCHA, V.M. de.; CENTURIÃO, C.H. Profissionais da saúde: formação, competência e responsabilidade social. Educação física e saúde coletiva: políticas de formação e perspectivas de intervenção / organizado por Alex Branco Fraga e Felipe Wachs. - Porto Alegre: Editora da UFRGS, 2007.

153. ROEMER, E.C.; KENT, K.B.; SAMOLY, D.K.; GAYDOS, L.M.; SMITH, K.J.; AGARWAL; A., et al. Reliability and valid ity testing of the CDC Worksite Health ScoreCard: an assessment tool to help employers prevent heart disease, stroke, and related health conditions. J Occup Environ Med. v.55. n.5 p.520-6, 2013.

154. ROHDE, C.L.C. Qualidade de Vida no Trabalho sob a Perspectiva de Professores de Ensino Superior. Dissertação (mestrado). Curso de Mestrado do Programa de PósGraduação em Psicologia, Área de Concentração em Psicologia da Saúde, da Universidade Federal de Santa Maria (UFSM, RS); 2012.

155. SANTINI, Joarez; NETO, Vicente Molina. A síndrome do esgotamento profissional em professores de educação física: um estudo na rede municipal de ensino de Porto Alegre.

Revista brasileira de Educação Física e Esporte, v. 19, n. 3, p. 209-222, 2005.

156. SANTOS, E.H. Trabalho prescrito e trabalho real no atual mundo do trabalho. Trabalho \& Educação, NETE, n. 1, p. 14-27, fev-jul, 1997.

157. SANTOS, G. B. dos. A fênix renasce das cinzas: os professores e seus mecanismos de fuga e enfrentamento. VI Seminário da Redestrado - Regulação Educacional e Trabalho Docente. Rio de Janeiro, RJ: UERJ, 2006. Disponível em: <www.fae.ufmg.br/estrado/cd_viseminario/.../a_fenix_renasce.pdf>. Acesso em: $03 \mathrm{fev}$. 2015.

158. SANTOS, G.B. Bem Estar e Condições de Trabalho de Professores do Centro de Ciências da Saúde da Universidade Federal de Pernambuco. Recife: Dissertação (mestrado) Universidade Federal de Pernambuco, CCS, Programa de Pós-Graduação Integrado em Saúde Coletiva; 2013.

159. SANTOS, L.M.dos.; ROS, M.A.Da.; CREPALDI, M.A.; RAMOS, L.R. Grupos de promoção à saúde no desenvolvimento da autonomia, condições de vida e saúde. Rev Saúde Pública. v.40. n.2. p.346-52, 2006.

160. SCHMITT, J.A.; FRANK, R.; BORELLA, D.R.; HARNISCH, G.S.; STORCH, J.A. Percepção dos Acadêmicos de Educação Física em Relação à Formação Profissional para Atuação junto à Alunos com Deficiência. Santa Maria: Revista Kinesis, v. 33, n.1, jan-jun de 2015. 
161. SERVILHA, E.A.M.; ARBACH, M.P. Queixas de Saúde em Professores Universitários e sua Relação com os Fatores de Risco Presentes na Organização do Trabalho. Revista Distúrbio Comunitário, São Paulo. v.23. p.2. p.181-191, agosto, 2011.

162. SERVILHA, E.A.M. Estresse em Professores Universitários na Área de Fonoaudiologia. Rev. Ciências Med. Campinas. v.14. n.1. p.43-52, Jan/Fev., 2005.

163. SÍCOLI, J.L.; NASCIMENTO, P.R. do. Promoção de saúde: concepções, princípios e operacionalização. Interface - Comunição, Saúde, Educ, v.7. n.12. p.101-22, fev, 2003.

164. SILVA, I.J.; OLIVEIRA, M.F.V; SILVA, S.E.D.; POLARO, S.H.I.; RADUNZ, V.; SANTOS, E.K.A.; SANTANA, M.E. Cuidado, autocuidado e cuidado de si: compreensão paradigmática para o cuidado de enfermagem. Revista Esc Enfermagem USP, 2009.

165. SILVA, A.; BRITO, I. Instituições de ensino superior promotoras de saúde. In R. Pedroso, \& I. Brito (Eds.), Saúde dos estudantes do ensino superior de enfermagem: estudo de contexto na Escola Superior de Enfermagem de Coimbra. Série Monográfica Educação e Investigação em Saúde (pp.17-31). Coimbra: Unidade de Investigação em Ciências da Saúde: Enfermagem (UICISA: E) / Escola Superior de Enfermagem de Coimbra (ESEnfC), 2014.

166. SILVA, E.P.; SILVA, JR. J.R. Estranhamento e Desumanização nas Relações de Trabalho na Instituição Universitária Pública. Revista HISTEDBR On-line, Campinas, número especial, p.223-238, ISSN: 1676-2584, ago.2010.

167. SILVA, M.F.G. da.; GARCIA, F.C. Dinâmica prazer e sofrimento em unidades de alimentação e nutrição (UAN). IN: XXXIII Encontro da Associação Nacional de PósGraduação e Pesquisa em Administração - ENANPAD. Anais. São Paulo:Anpad, 2009.

168. SILVA, M.P.da;; PINHEIRO, M.F.G. Corporeidade, Educação Física e a formação de crianças na Educação Infantil. Revista Formação@Docente - Belo Horizonte - v. 5, n.1, jan/jun 2013.

169. SILVA, N.P. da.; MARINHO, F.P.; LIMA, K.Y.N.de.; RODRIGUES, C.C.F.M.; SANTOS, V.E.P. Docência Universitária e o Estresse: Estressores nos Cursos de Enfermagem e Medicina. Rev Enferm. UFSM; Jan./Mar.; v.6. n.1. p.61-70; 2016.

170. SILVÉRIO, M.R.; PATRÍCIO, Z.M.; BROADBECK, I.M.; GROSSEMAN, S. O Ensino na Área de Saúde e sua repercussão da Qualidade de Vida Docente. Revista Brasileira de Educação Médica; 34(1): 65-73, 2010.

171. SOÁREZ, Patrícia Coelho de; CICONELLI, Rozana Mesquita. Tradução e adaptação cultural do questionário CDC worksite health scorecard (HSC), Promoção da saúde e prevenção de riscos e doenças na saúde suplementar brasileira. Alberto José N.Ogata (org); 2013.

172. SOUZA, S.M.; SOUTO, L.E.S.; LIMA, C.A.; LACERDA, M.K.S.; VIEIRA, M.A.; COSTA, F.M. Caracterização Sociodemográfica de Docentes da Área da Saúde. Revista Norte Mineira de Enfermagem. 2015;4(1):15- 28. 
173. TARDIF, Maurice. Saberes profissionais dos professores e conhecimentos universitários. Revista Brasileira de Educação, Rio de Janeiro, v. 13, n. 5, p. 5-24, 2000.

174. TELLES, A.L.; ALVAREZ, D. Interfaces ergonomia-ergologia: uma discussão sobre trabalho prescrito e normas antecedentes. Cap. 3. In: FIGUEIREDO, M. et al. (org.). Labirintos do trabalho: interrogações e olhares sobre o trabalho vivo. Rio de Janeiro: DP\&A, p. 63-89, 2004.

175. TENFEN, W. O processo de (des)qualificação do professor. Florianópolis. Dissertação (Mestrado em Educação) - Programa de Pós-Graduação em Educação, Universidade Federal de Santa Catarina, 1992.

176. TIBURRI, Roberta. O Sujeito Sociológico pelas ruas de Brasília. Rev. Pós v.20 n.34, São Paulo, Dez. 2013.

177. TREVISO P. Percepção de profissionais da área da saúde sobre a formação, atuação e satisfação em sua atividade docente. Tese (Doutorado em Medicina e Ciências da Saúde - Área de Concentração em Nefrologia, Linha de Pesquisa Educação em Ciências da Saúde - Faculdade de Medicina, PUCRS. Porto Alegre, 224 f. : il. 2015.

178. TRINQUET, Pierre. Trabalho e educação: o método ergológico. Campinhas: Revista HISTEDBR On-line, número especial, p. 93-113, ISSN: 1676-2584, ago. 2010.

179. ULRICH E. Percepções de Professores Universitários sobre as Relações Interprofissionais que Levam a Estresse. Dissertação (mestrado). Programa de PósGraduação em Psicologia, Centro de Filosofia e Ciências Humanas da Universidade Federal de Santa Catarina; 2005.

180. UNB. Universidade de Brasília. Ato da Reitoria n 831/74. Brasília: Universidade de Brasília, 1974a.

181. Brasília, 1974b.

Ata da Reunião do Conselho Diretor n. 25/74. Brasília: Universidade de . Decanato de Gestão de Pessoas. Relatório de Atividades de 2015. 2015.

183. UnB terá cinco novos cursos em 2012. Disponível em:

<http://www.unb.br/noticias/unbagencia/unbagencia.php?id=5568. 2011 >. Acessado em: 05 fev. 2016.

184. . Novo Anuário Estatístico da UnB - 2015 (2010-2014). Decanato de Planejamento e Orçamento (DPO). 2015.

185. UNESP. Interface - Comunicação, Saúde, Educação. Editada pela Unesp (Laboratório de Educação e Comunicação em Saúde, Departamento de Saúde Pública, Faculdade de Medicina de Botucatu e Instituto de Biociências de Botucatu), Botucatu, SP: Unesp Interface - comunicação, saúde, educação, Supl 1, 2015. 
186. VIEIRA, Jr. P.R. Renormalizações: estratégias para manutenção da saúde pela atividade docente. Dissertação apresentada (Mestrado em Gestão Social, Educação e Desenvolvimento). Local do Centro Universitário UNA, p.196, 2011.

187. WACHS, F. Educação física e o campo da saúde mental: uma reflexão introdutória. Educação física e saúde coletiva: políticas de formação e perspectivas de intervenção / organizado por Alex Branco Fraga e Felipe Wachs. - Porto Alegre: Editora da UFRGS, 2007.

188. WENZEL, R. L. O professor e o trabalho abstrato: uma análise da (des)

qualificação do professor. Florianópolis. Dissertação (Mestrado em Educação) - Programa de Pós-Graduação em Educação, Universidade Federal de Santa Catarina, 1991.

189. ZANELLI, C. J.; BORGES, A. E. J.; BASTOS, B. V. A. Psicologia, organizações e trabalho. Porto Alegre: Artmed, 2004. 


\title{
LISTA DE APENNDICES
}

\section{APÊNDICE A. APROVAÇÃO DA COORDENAÇÃO FEF}

\author{
Y \\ UNIVERSIDADE DE BRASÍLIA \\ FACULDADE DE EDUCAÇÃO FÍSICA \\ TERMO DE CONCORDÂNCIA
}

A Faculdade de Educação Física da Universidade de Brasília, por meio da professora orientadora Dra . Júlia Aparecida Devidé Nogueira e de seu diretor, o professor Dr. Jake Carvalho do Carmo atesta ser instituição proponente e estar de acordo com a realização da pesquisa intitulada: Saúde dos Professores Universitários da Área de Saúde e o Autocuidado Apoiado, de responsabilidade da pesquisadora Andrea Ferreira Leite, para fins de estudo científico de mestrado, após aprovação pelo Comitê de Ética em Pesquisa da com Seres Humanos da Faculdade de Ciências da Saúde da Universidade de Brasília.

A primeira etapa do estudo é exploratória, onde a obtenção das informações ocorrerão mediante contato direto da pesquisadora com os professores da área da grande área da saúde da Faculdade de Educação Física e Faculdade de Saúde, da Universidade de Brasília. A seguir serão realizadas entrevistas com os docentes sobre práticas corporais e promoção da saúde; que todo material das falas serão gravado, transcrito, analisado e divulgado de acordo com os princípios éticos da pesquisa qualitativa em saúde, inclusive os contidos na resolução 466/2012 do Conselho Nacional de Saúde. A coleta de informações ocorrerá entre abril a setembro de 2015.

Brasília, 24 de abril de 2015.

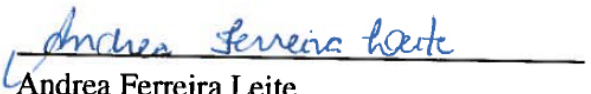

Andrea Ferreira Leite

Pesquisadora Responsável pelo protocolo de pesquisa



Dra Júlia Aparecida Devide Nogueira

Orientadora da pesquisa e professora da Pós Graduação da Faculdade de Educação Física

Dr. Jake Carvalhodo Carmo

Diretơr da Faculdade de Educação Física da Universidade de Brasília.

$$
\begin{gathered}
\text { Prof. Jake Carvalho do Carmo } \\
\text { Diretor } \\
\text { Faculdade de Educacáo Fisical UnB } \\
\text { Matricula } 770019
\end{gathered}
$$




\title{
APÊNDICE B. TERMO DE CONSENTIMENTO LIVRE ESCLARECIDO (TCLE)
}

\author{
Universidade de Brasília \\ Faculdade de Educação Física - Pós Graduação
}

\section{Termo de Consentimento Livre e Esclarecido}

Convidamos você a participar da pesquisa de mestrado intitulada: SAÚDE DE PROFESSORES UNIVERSITÁRIOS DA EDUCAÇÃO FÍSICA E O AUTOCUIDADO APOIADO, sob a responsabilidade da aluna Andrea Ferreira Leite e sob orientação da Professora Doutora Júlia Aparecida Devidé Nogueira.

Essa pesquisa foi Aprovada pelo Comitê de Ética em Pesquisa da Faculdade de Ciências da Saúde da Universidade de Brasília (FS/UnB n ${ }^{\circ}$. 035722/2015), e tem como objetivo conhecer a situação de saúde dos professores da Faculdade de Educação Física e o autocuidado apoiado no contexto da Universidade de Brasília.

Sua participação é voluntária, porém fundamental para nos ajudar a compreender esses complexos fenômenos da saúde considerando o ambiente de trabalho como um espaço promotor, ou não, de saúde. Caso aceite participar, deverá responder a dois questionários com duração estimada de 20 minutos, além de assinar esse Termo de Consentimento Livre e Esclarecido.

Lhe asseguramos que os dados coletados por esses instrumentos tem finalidade exclusiva de pesquisa científica e serão mantidos em sigilo. Os questionários respondidos ficarão sob a guarda da pesquisadora por um período de cinco anos, após isso serão destruídos. A divulgação dos dados respeitará os preceitos éticos e não permitirá sua identificação individual. Mesmo assim, caso não se sinta confortável em responder alguma das questões ou queira se retirar da pesquisa a qualquer momento, não haverá nenhum prejuízo para você. Os resultados da pesquisa serão publicados em periódicos científicos e apresentados à esse mesmo Conselho.

Caso haja qualquer dúvida coloco-me à disposição para esclarecimentos. Se preferirem poderão contatar a pesquisadora Andrea Ferreira Leite no telefone (61) 9966-5254; a orientadora Júlia Aparecida Devidé Nogueira no telefone (61) 8112-7346; ou o Comitê de Ética da FS/UnB no telefone (61) 3107-1947.

Agradecemos antecipadamente a atenção dispensada.

Brasília, de de 2015. 


\section{APÊNDICE C. ROTEIRO SEMI ESTRUTURADO}

\begin{tabular}{|c|c|}
\hline $\begin{array}{l}\text { Eixo 1-Aspectos sobre } \\
\text { a saúde: }\end{array}$ & $\begin{array}{l}\text { 1. Como você se sente a respeito de sua saúde? } \\
\text { i. De acordo com a resposta irei categorizar positiva, } \\
\text { negativa, neutra. } \\
\text { a) Se a resposta for relacionada ao aspecto negativo } \\
\text { e neutro, irei buscar mais informações sobre } \\
\text { problemas físicos, psicológicos e sociais (tais } \\
\text { como: dores, distúrbios, alteração no sono, } \\
\text { vontade de ficar sozinho). } \\
\text { b) Se a resposta for relacionada ao aspecto positivo, } \\
\text { solicitar que o professor, ressalte os aspectos } \\
\text { positivos. }\end{array}$ \\
\hline $\begin{array}{l}\text { Eixo } 2 \text { - Aspectos sobre } \\
\text { a Promoção da Saúde: }\end{array}$ & $\begin{array}{l}\text { 1. O que você faz para promover sua saúde? } \\
\text { i. O cuidado de si (ver o que são consideradas práticas } \\
\text { promotoras de saúde, classificar em com base nos } \\
\text { princípios e valores da chamada "nova promoção da } \\
\text { saúde", "antiga PS", e assistencialista biomédica). } \\
\text { ii. Práticas corporais aparecem no discurso do professor ou } \\
\text { e a atividade física? }\end{array}$ \\
\hline & $\begin{array}{l}\text { 2. Como são suas práticas corporais (atividade física)? } \\
\text { i. Faz regularmente, faz irregularmente ou não faz. } \\
\text { ii. Motivo por que faz (saúde, prazer, doença, lazer, cultura) } \\
\text { - definidas a posteriori. }\end{array}$ \\
\hline & $\begin{array}{l}\text { 3. Que possibilidades promotoras de saúde seu ambiente de } \\
\text { trabalho }(\mathrm{UnB}) \text { oferece/ proporciona? } \\
\text { i. Práticas corporais /FEF aparece? - o autocuidado } \\
\text { apoiado }\end{array}$ \\
\hline & $\begin{array}{l}\text { 4. Que aspectos você considera produtores de adoecimento em seu } \\
\text { ambiente de trabalho (UnB/ FEF)? }\end{array}$ \\
\hline
\end{tabular}


LISTA DE ANEXOS

ANEXO I. OS COMPONENTES DO CARTÃO DE PONTUAÇÃO DO APOIO À SAÚDE NO LOCAL DE TRABALHO.

\begin{tabular}{|c|c|c|}
\hline \multicolumn{3}{|l|}{ Suporte Organizacional } \\
\hline Durante os últimos 12 meses, o seu local de trabalho: & Sim & Não \\
\hline $\begin{array}{l}\text { 1) Avaliou interesses e necessidades dos funcionários para planejar atividades de } \\
\text { promoção da saúde? } \\
\text { Responda SIM se você acredita que a UnB realiza pesquisas para avaliar programas } \\
\text { de promoção da saúde para os funcionários. Responda NÃO se houver apenas } \\
\text { pesquisas gerais. }\end{array}$ & $\begin{array}{l}(\quad) \\
(1 \text { pt. })\end{array}$ & $\begin{array}{l}\text { ( }) \\
(0 \text { pt. })\end{array}$ \\
\hline $\begin{array}{l}\text { 2) Demonstrou apoio e comprometimento organizacionais voltados à promoção da saúde } \\
\text { no local de trabalho em todos os níveis hierárquicos? } \\
\text { Responda SIM se vários níveis hierárquicos participam das atividades elou ou o } \\
\text { sentimento de pertencimento ao programa é compartilhado pelos vários níveis } \\
\text { organizativos. }\end{array}$ & $\begin{array}{l}(\quad) \\
(2 \text { pt. })\end{array}$ & 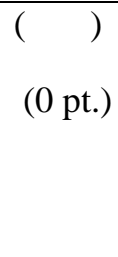 \\
\hline $\begin{array}{l}\text { 3) Usou incentivos combinados a outras estratégias, para aumentar a participação em } \\
\text { programas de promoção da saúde? } \\
\text { Responda SIM se a UnB oferece incentivos (vales-presentes, dinheiro, folgas } \\
\text { remuneradas, descontos em produtos, serviços ou planos de saúde, reconhecimento } \\
\text { ou prêmios). }\end{array}$ & $\begin{array}{l}(\quad) \\
(2 \text { pt. })\end{array}$ & $\begin{array}{l}\left(\begin{array}{l}\text { ( } \\
(0 \mathrm{pt} .)\end{array}\right.\end{array}$ \\
\hline $\begin{array}{l}\text { 4) Promoveu e divulgou programas de promoção da saúde para seus funcionários? } \\
\text { Responda SIM se o programa de promoção da saúde da UnB possuir marca ou } \\
\text { logotipo, utilizar diferentes canais de comunicação, ou enviar mensagens frequentes. }\end{array}$ & $\begin{array}{l}(\quad) \\
(1 \mathrm{pt} .)\end{array}$ & 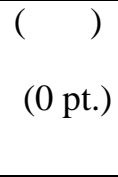 \\
\hline $\begin{array}{l}\text { 5) Adaptou programas de promoção da saúde e materiais educativos à língua, ao grau de } \\
\text { instrução e à cultura dos diferentes segmentos da força de trabalho? } \\
\text { Responda NÃO se você acredita que a UnB não necessita adaptar seus programas de } \\
\text { promoção da saúde e materiais educativos para grupos específicos. }\end{array}$ & $\begin{array}{l}\left(\begin{array}{l}) \\
(3 \mathrm{pt} .)\end{array}\right.\end{array}$ & $\begin{array}{l}\left(\begin{array}{r}\text { ) } \\
(0 \mathrm{pt} .)\end{array}\right.\end{array}$ \\
\hline $\begin{array}{l}\text { 6) Conduziu avaliações contínuas da programação de promoção da saúde com a } \\
\text { utilização de diferentes fontes de dados? } \\
\text { Responda SIM se você acredita que a UnB coleta dados sobre os riscos à saúde, } \\
\text { gastos com assistência médica, satisfação dos funcionários, ou pesquisas de clima } \\
\text { organizacional. }\end{array}$ & $\begin{array}{l}(\quad) \\
(2 \mathrm{pt} .)\end{array}$ & 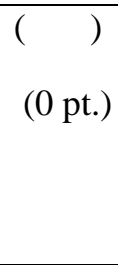 \\
\hline $\begin{array}{l}\text { 7) Disponibilizou algum programa de promoção da saúde para familiares de } \\
\text { funcionários? }\end{array}$ & $\begin{array}{l}(\quad) \\
(1 \text { pt. })\end{array}$ & $\begin{array}{l}\left(\begin{array}{r}(\quad) \\
(0 \mathrm{pt} .)\end{array}\right.\end{array}$ \\
\hline $\begin{array}{l}\text { 8) Implantou políticas de horários de trabalho flexíveis? } \\
\text { Responda SIM se as políticas permitirem horários flexíveis e trabalho em casa. }\end{array}$ & $\begin{array}{l}(\quad) \\
(2 \text { pt. })\end{array}$ & 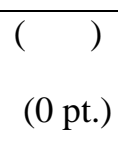 \\
\hline $\begin{array}{l}\text { 9) Participou de outras iniciativas voltadas à saúde na comunidade e apoiou a } \\
\text { participação de funcionários e o trabalho voluntário? } \\
\text { Responda SIM se a UnB apoia a participação em eventos comunitários e iniciativas } \\
\text { em escolas; ou colabora com outros grupos organizados em nível local ou estadual. }\end{array}$ & 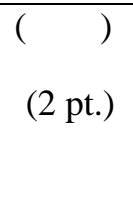 & $\begin{array}{l}\left(\begin{array}{r}\text { ( } \\
(0 \mathrm{pt} .)\end{array}\right.\end{array}$ \\
\hline o seu local de trabalho da seção suporte organizacional & & \\
\hline
\end{tabular}




\begin{tabular}{|c|c|c|}
\hline Pontuação máxima da seção suporte organizacional & & \\
\hline \multicolumn{3}{|l|}{ Atividade Física } \\
\hline Durante os últimos 12 meses, o seu local de trabalho: & Sim & Não \\
\hline 1) Disponibilizou instalações para a prática de atividade física no local de trabalho? & $\begin{array}{l}(\quad) \\
(3 \text { pt. })\end{array}$ & 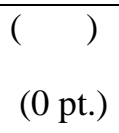 \\
\hline $\begin{array}{l}\text { 2) Subsidiou ou deu descontos no uso de instalações para prática de atividade física no } \\
\text { local de trabalho ou fora dele? }\end{array}$ &  & 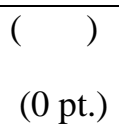 \\
\hline $\begin{array}{l}\text { 3) Disponibilizou outros tipos de suporte à atividade física ou recreativa? } \\
\text { Responda SIM se você acredita que a UnB possui pistas para caminhada, } \\
\text { bicicletários, quadra esportiva, espaço destinado à prática de atividades recreativas } \\
\text { e vestiários. }\end{array}$ & $\begin{array}{l}\left(\begin{array}{l}\text { ) } \\
(3 \mathrm{pt} .)\end{array}\right.\end{array}$ & $\begin{array}{l}\left(\begin{array}{r}) \\
(0 \mathrm{pt} .)\end{array}\right.\end{array}$ \\
\hline $\begin{array}{l}\text { 4) Colocou avisos em elevadores, portas de acesso às escadas e outros locais-chave, } \\
\text { estimulando os funcionários a utilizar as escadas? } \\
\text { Responda NÃO se o seu local de trabalho está situado em um prédio térreo. }\end{array}$ & $\begin{array}{l}(\quad) \\
(3 \text { pt. })\end{array}$ & $\begin{array}{c}\left(\begin{array}{c}) \\
(0 \text { pt. })\end{array}\right.\end{array}$ \\
\hline $\begin{array}{l}\text { 5) Proporcionou programas organizados para prática de atividades físicas individuais ou } \\
\text { em grupo para funcionários (além do uso de instalações para prática de exercícios)? } \\
\text { Responda SIM se você acredita que a UnB possui programas de exercícios. }\end{array}$ & $\begin{array}{l}(\quad) \\
(3 \text { pt. })\end{array}$ & 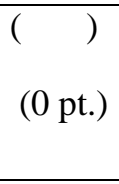 \\
\hline $\begin{array}{l}\text { 6) Distribuiu folhetos, vídeos, cartazes, panfletos, informativos ou outras informações } \\
\text { em papel ou online que tratassem dos benefícios da atividade física? } \\
\text { Responda SIM se os materiais de promoção da saúde tratarem dos benefícios da } \\
\text { atividade física como um tema único ou se estiverem incluídos em outros temas de } \\
\text { saúde. }\end{array}$ & $\begin{array}{l}(\quad) \\
(1 \text { pt. })\end{array}$ & 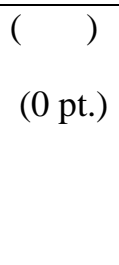 \\
\hline $\begin{array}{l}\text { 7) Realizou algumas aulas, oficinas ou seminários educativos sobre atividade física? } \\
\text { Responda SIM se as sessões tratarem de atividade física como tema único ou } \\
\text { incluída em outros temas de saúde. Podem ser presencial ou online, no local de } \\
\text { trabalho ou fora dele, em grupo ou individual, por meio de funcionários ou terceiros. }\end{array}$ & $\begin{array}{l}(\quad) \\
(2 \text { pt. })\end{array}$ & $\begin{array}{l}\left(\begin{array}{r}) \\
(0 \mathrm{pt} .)\end{array}\right.\end{array}$ \\
\hline $\begin{array}{l}\text { 8) Realizou ou subsidiou avaliações de condicionamento físico, aconselhamento, } \\
\text { acompanhamento ou indicação de atividades físicas no local de trabalho ou em } \\
\text { instalações comunitárias para prática de exercícios? }\end{array}$ & $\left(\begin{array}{r}\text { ( }) \\
(3 \mathrm{pt} .)\end{array}\right.$ & $\begin{array}{c}(\quad) \\
(0 \mathrm{pt} .)\end{array}$ \\
\hline $\begin{array}{l}\text { 9) Disponibilizou programas de autogerenciamento de atividade física? } \\
\text { Responda SIM se os programas forem oferecidos de forma presencial ou online, no } \\
\text { local de trabalho ou fora dele, em grupo ou individualmente, por meio de } \\
\text { funcionários ou terceiros. }\end{array}$ & $\left(\begin{array}{r}\text { ( }) \\
(3 \mathrm{pt} .)\end{array}\right.$ & $\begin{array}{r}(\quad) \\
(0 \mathrm{pt} .)\end{array}$ \\
\hline Pontuação do seu local de trabalho da seção atividade física & & \\
\hline Pontuação máxima da seção atividade física & \multicolumn{2}{|c|}{24} \\
\hline \multicolumn{3}{|l|}{ Gerenciamento de Estresse } \\
\hline Durante os últimos 12 meses, o seu local de trabalho: & Sim & Não \\
\hline $\begin{array}{l}\text { 1) Proporcionou espaços específicos para os funcionários realizarem atividades de } \\
\text { relaxamento, tais como meditação, yoga, ou biofeedback? }\end{array}$ & $\left(\begin{array}{r}\text { ( }) \\
(1 \mathrm{pt} .)\end{array}\right.$ & $\left(\begin{array}{r}\quad) \\
(0 \mathrm{pt} .)\end{array}\right.$ \\
\hline
\end{tabular}




\begin{tabular}{|c|c|c|}
\hline $\begin{array}{l}\text { 2) Patrocinou ou organizou eventos sociais ao longo do ano? } \\
\text { Responda SIM se você acredita que a UnB patrocina ou organiza eventos para } \\
\text { entrosamento de equipes, celebração de datas festivas, ou times de funcionários para } \\
\text { prática de esportes. }\end{array}$ & 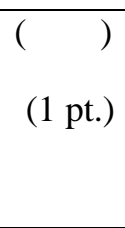 & $\begin{array}{l}\left(\begin{array}{l}\text { ) } \\
(0 \mathrm{pt} .)\end{array}\right.\end{array}$ \\
\hline $\begin{array}{l}\text { 3) Disponibilizou programas de gerenciamento de estresse? } \\
\text { Responda SIM se os programas tratarem de gerenciamento de estresse como tema } \\
\text { único ou incluído em outros temas de saúde. Podem ser presencial on online, no } \\
\text { local de trabalho ou fora dele, em grupo ou individual, por meio de funcionários ou } \\
\text { terceiros. }\end{array}$ & $\begin{array}{l}(\quad) \\
(3 \mathrm{pt} .)\end{array}$ & $\begin{array}{l}(\quad) \\
(0 \text { pt. })\end{array}$ \\
\hline $\begin{array}{l}\text { 4) Ofereceu programas sobre competência pessoal ou equilíbrio do trabalho e vida } \\
\text { pessoal? } \\
\text { Responda SIM se você acredita que a UnB oferece serviços voltados ao atendimento } \\
\text { da terceira idade, creche ou serviços voltados ao cuidado de crianças, indicaçes de } \\
\text { serviços, reembolso de mensalidades ou honorários, ou outros; oferecidos por } \\
\text { funcionários ou terceiros. }\end{array}$ & $\begin{array}{l}(\quad) \\
(3 \text { pt. })\end{array}$ & 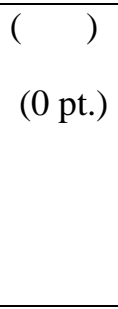 \\
\hline $\begin{array}{l}\text { 5) Proporcionou aos gerentes treinamento para identificar e reduzir questões relacionadas } \\
\text { ao estresse no local de trabalho? } \\
\text { Responda SIM se você acredita que a UnB oferece treinamentos sobre avaliação de } \\
\text { desempenho, comunicação, gestão de pessoal, gestão de tempo ou resolução de } \\
\text { conflitos. }\end{array}$ & $\begin{array}{l}(\quad) \\
(3 \text { pt. })\end{array}$ & 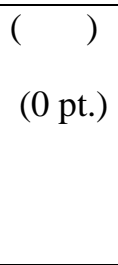 \\
\hline $\begin{array}{l}\text { 6) Proporcionou oportunidades para que funcionários participassem das decisões } \\
\text { organizacionais envolvendo questões que afetem o estresse no local de trabalho? } \\
\text { Responda SIM se você acredita que a UnB dá oportunidades aos funcionários para } \\
\text { participem nas decisões sobre ambiente e processo de trabalho, horário de trabalho, } \\
\text { e problemas e gestão. }\end{array}$ & $\begin{array}{l}\left(\begin{array}{l}\text { ( }) \\
(3 \mathrm{pt} .)\end{array}\right.\end{array}$ & 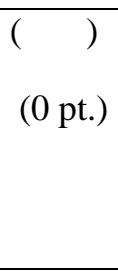 \\
\hline Pontuação do seu local de trabalho da seção gerenciamento de estresse & & \\
\hline
\end{tabular}




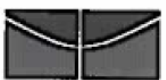 \\ Universidade de Brasilia \\ Faculdade de Ciências da Saúde \\ Comitê de Élica em Pesquisa - CEP/FS \\ PROCESSO DE ANÁLISE DE PROJETO DE PESOUISA
}

TítUlo do PROJETO: "SAÚDE DE PROFESSORES UNIVERSITÁRIOS DA ÁREA DE SAÚDE E O AUTOCUIDADO APOIADO."

PESQUISADORA RESPONSÁVEL: ANDREA FERREIRA LEITE

DATA DE ENTRADA: 04/08/2015

CAAE: 44493915.1 .0000 .0030

Com base na Resoluçāo 466/12, do CNS/MS, que regulamenta a élica em pesquisa com seres humanos, o Comitê de Ética em Pesquisa com Seres Humanos da Faculdade de Ciências da Saúde da Universidade de Brasília, após análise dos aspectos éticos e do conlexto técnico-científico, resolveu APROVAR o projeto intitulado "SAÚDE DE PROFESSORES UNIVERSITÁRIOS DA ÁREA DE SAÚDE E O AUTOCUIDADO APOIADO." Parecer n⿳0 1.168.660, em 03 de agosto de 2015.

Notifica-se o(a) pesquisador(a) responsável da obrigatoriedade da apresentaçăo de relatório(s) scmestral(ais) e relatório final sobre o desenvolvimento do projeto a contar da data de aprovação do projeto inicial.

Brasília, 22 de junho de 2016.

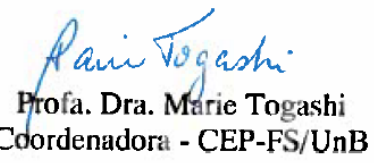

Comitê de Élica em Pesquisa com Seres Hlumanos - Faculdade de Ciências da Saúde
Universidade de Brasilia - Campus Universitário Darcy Ribciro - CIF: $70.910-900$

Telefone: (51)-3107-1947 Email: cepfs(aunb.br 


\section{ANEXO III. DADOS GERAIS DOS DOCENTES}

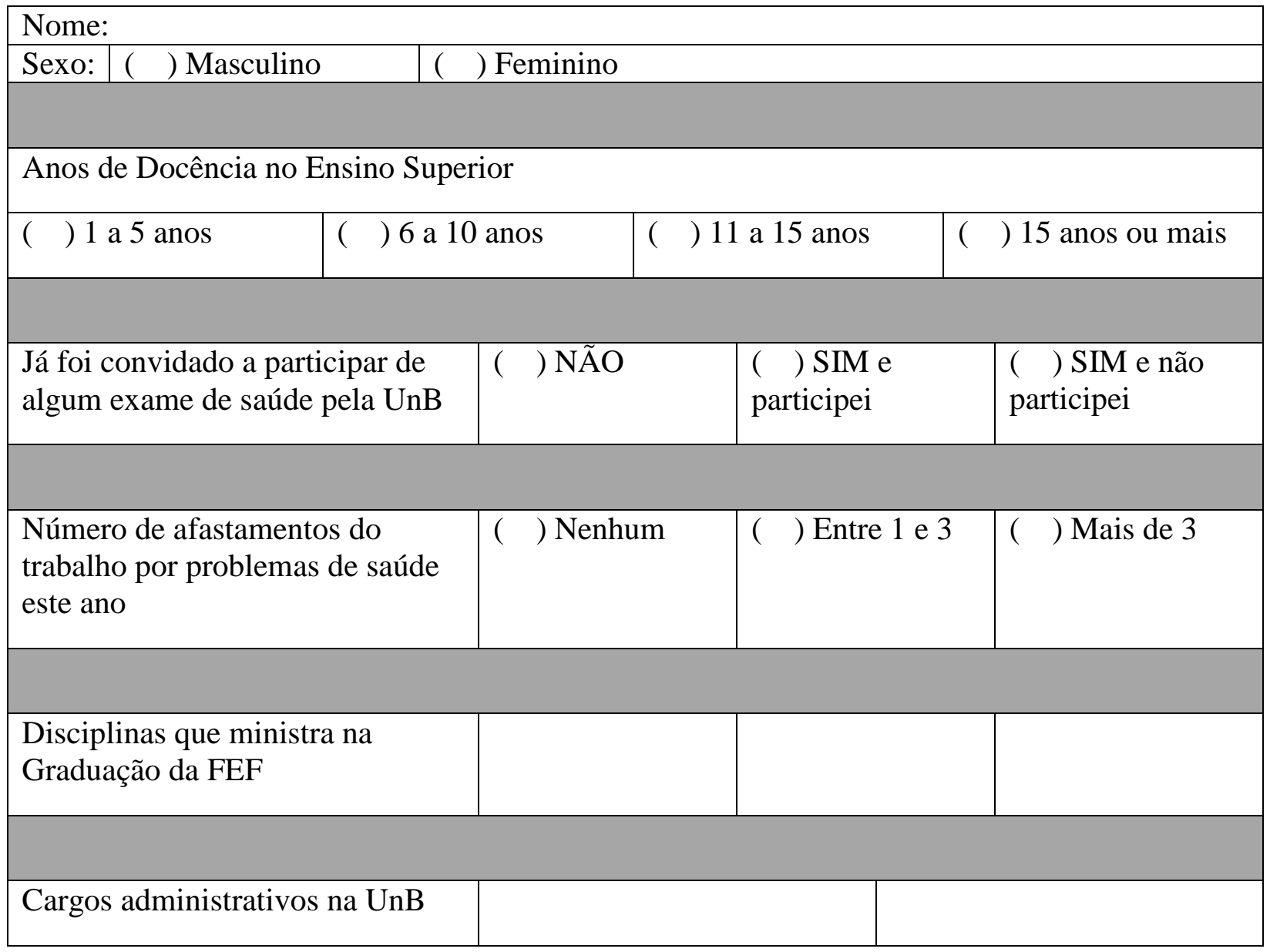


ANEXO IV. QUESTIONÁRIO ESCALA DE AVALIAÇÃO DO CONTEXTO DE TRABALHO

Escolha a alternativa que melhor corresponde à avaliação que você faz do seu contexto
de trabalho:

\begin{tabular}{|c|c|c|c|c|c|}
\hline O ritmo de trabalho é excessivo & 1 & 2 & 3 & 4 & 5 \\
\hline As tarefas são cumpridas com pressão de prazos & 1 & 2 & 3 & 4 & 5 \\
\hline Existe forte cobrança por resultados & 1 & 2 & 3 & 4 & 5 \\
\hline As normas para execução das tarefas são rígidas & 1 & 2 & 3 & 4 & 5 \\
\hline Existe fiscalização do desempenho & 1 & 2 & 3 & 4 & 5 \\
\hline O número de pessoas é insuficiente para se realizar as tarefas & 1 & 2 & 3 & 4 & 5 \\
\hline Os resultados esperados estão fora da realidade & 1 & 2 & 3 & 4 & 5 \\
\hline Existe divisão entre quem planeja e quem executa & 1 & 2 & 3 & 4 & 5 \\
\hline As tarefas são repetitivas & 1 & 2 & 3 & 4 & 5 \\
\hline Falta tempo para realizar pausas de descanso no trabalho & 1 & 2 & 3 & 4 & 5 \\
\hline As tarefas executadas sofrem descontinuidade & 1 & 2 & 3 & 4 & 5 \\
\hline As tarefas não estão claramente definidas & 1 & 2 & 3 & 4 & 5 \\
\hline A autonomia é inexistente & 1 & 2 & 3 & 4 & 5 \\
\hline A distribuição das tarefas é injusta & 1 & 2 & 3 & 4 & 5 \\
\hline Os funcionários são excluídos das decisões & 1 & 2 & 3 & 4 & 5 \\
\hline Existem dificuldades na comunicação entre chefia e subordinados & 1 & 2 & 3 & 4 & 5 \\
\hline Existem disputas profissionais no local de trabalho & 1 & 2 & 3 & 4 & 5 \\
\hline Falta integração no ambiente de trabalho & 1 & 2 & 3 & 4 & 5 \\
\hline A comunicação entre funcionários é insatisfatória & 1 & 2 & 3 & 4 & 5 \\
\hline Falta apoio das chefias para o meu desenvolvimento profissional & 1 & 2 & 3 & 4 & 5 \\
\hline $\begin{array}{l}\text { As informações que preciso para executar minhas tarefas são de difícil } \\
\text { acesso }\end{array}$ & 1 & 2 & 3 & 4 & 5 \\
\hline As condições de trabalho são precárias & 1 & 2 & 3 & 4 & 5 \\
\hline O ambiente físico é desconfortável & 1 & 2 & 3 & 4 & 5 \\
\hline Existe muito barulho no ambiente de trabalho & 1 & 2 & 3 & 4 & 5 \\
\hline O mobiliário existente no local de trabalho é inadequado & 1 & 2 & 3 & 4 & 5 \\
\hline Os instrumentos de trabalho são insuficientes para realizar as tarefas & 1 & 2 & 3 & 4 & 5 \\
\hline O posto/estação de trabalho é inadequado para realização das tarefas & 1 & 2 & 3 & 4 & 5 \\
\hline Os equipamentos necessários para realização das tarefas são precários & 1 & 2 & 3 & 4 & 5 \\
\hline O espaço físico para realizar o trabalho é inadequado & 1 & 2 & 3 & 4 & 5 \\
\hline As condições de trabalho oferecem riscos à segurança das pessoas & 1 & 2 & 3 & 4 & 5 \\
\hline O material de consumo é insuficiente & 1 & 2 & 3 & 4 & 5 \\
\hline
\end{tabular}

\section{Obrigado por sua participação!}

